LETICIA MARTINS PAIVA

A INSERÇÃO DAS DISCIPLINAS DE ÉTICA, DEONTOLOGIA E BIOÉTICA NOS CURSOS DE GRADUAÇÃO EM FISIOTERAPIA EM UNIVERSIDADES E CENTROS UNIVERSITÁRIOS NO BRASIL 


\author{
UNIVERSIDADE DE BRASÍLIA \\ FACULDADE DE CIÊNCIAS DA SAÚDE \\ PROGRAMA DE PÓS-GRADUAÇÃO EM CIÊNCIAS DA SAÚDE
}

LETICIA MARTINS PAIVA

\title{
A INSERÇÃO DAS DISCIPLINAS DE ÉTICA, DEONTOLOGIA E BIOÉTICA NOS CURSOS DE GRADUAÇÃO EM FISIOTERAPIA EM UNIVERSIDADES E CENTROS UNIVERSITÁRIOS NO BRASIL
}

Tese apresentada como requisito para a obtenção do Título de Doutor em Ciências da Saúde pelo Programa de Pós-graduação em Ciências da Saúde da Universidade de Brasília.

Orientadora: Professora Dra. Dirce Guilhem

BRASÍLIA 
Ficha catalográfica elaborada automaticamente, com os dados fornecidos pelo(a) autor(a)

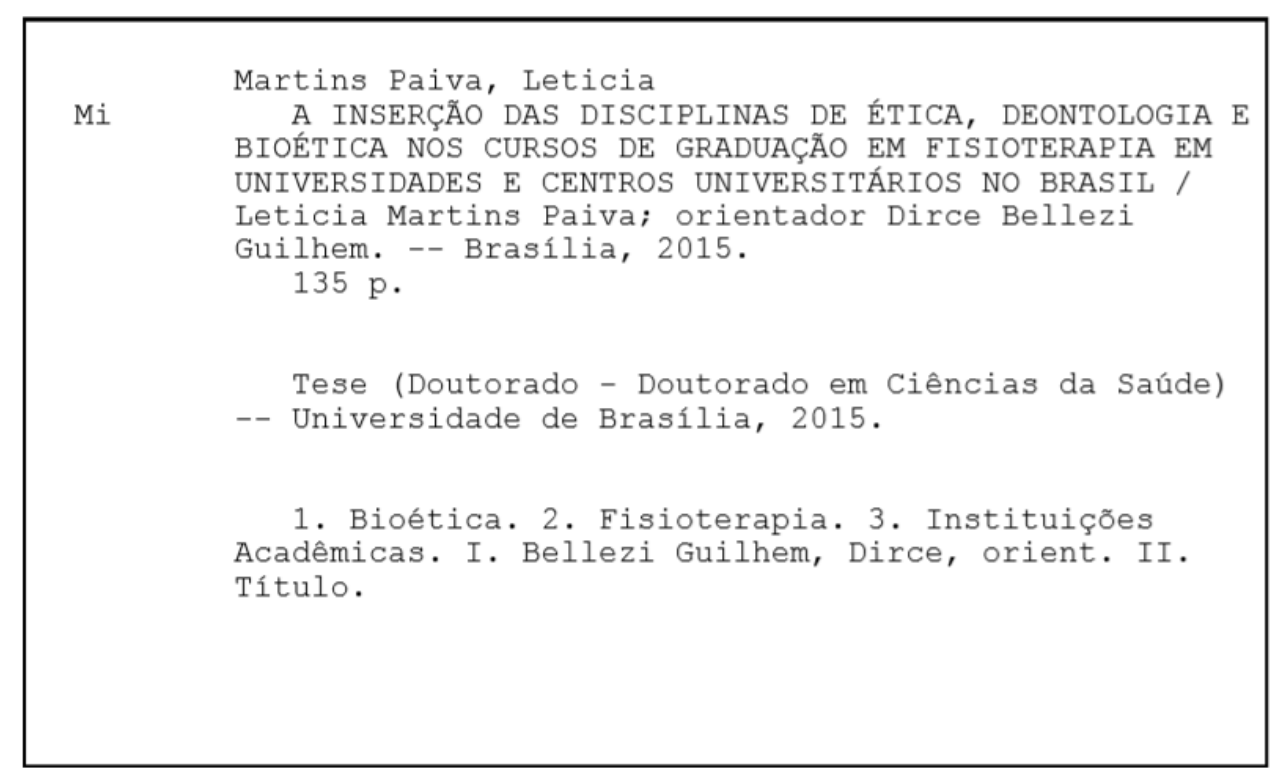




\title{
A INSERÇÃO DAS DISCIPLINAS DE ÉTICA, DEONTOLOGIA E BIOÉTICA NOS CURSOS DE GRADUAÇÃO EM FISIOTERAPIA EM UNIVERSIDADES E CENTROS UNIVERSITÁRIOS NO BRASIL
}

\author{
Tese apresentada como requisito para a \\ obtenção do Título de Doutor em Ciências da \\ Saúde pelo Programa de Pós-graduação em \\ Ciências da Saúde da Universidade de \\ Brasília.
}

Aprovado em 03 de julho de 2015.

BANCA EXAMINADORA

Profa. Dra. Dirce Bellezi Guilhem - Presidente Faculdade de Ciências da Saúde da Universidade de Brasília Programa de Pós-Graduação em Ciências da Saúde

Profa. Dra. Ana Luiza Lima Souza - Membro Efetivo/Externo à UnB Universidade Federal de Goiás - Faculdade de Enfermagem

Prof. Dr. Luiz Augusto Casulari Roxo da Mota - Membro Efetivo Hospital Universitário de Brasília - Programa de Pós-Graduação em Ciências da Saúde 
Prof. Dr. Pedro Sadi - Membro Efetivo

Faculdade de Ciências da Saúde da Universidade de Brasília

Profa. Dra. Flávia Aparecida Squinca - Membro Efetivo Hospital Universitário de Brasília

Profa. Dra. Fernanda Costa Vinhaes Lima - Membro Suplente Faculdade de Ciências da Educação e Saúde - UniCEUB 
Dedico este trabalho:

Ao meu pai Cícero e a minha mãe Gisele que são minha fortaleza e inspiração de vida em lutar pelos meus sonhos e objetivos. Ao meu marido Rubens pela convivência, pela paciência e pelo amor que nos mantém unidos e fortalecidos. Ao meu filho, meu pequeno Mariano, que me deu um novo sentido na vida e minha inspiração em viver. 


\section{AGRADECIMENTOS}

Foram quatro anos de perdas e ganhos. Sorrisos e lágrimas. Dessa forma, agradeço primeiramente a Deus por permitir que mais um sonho se concretize. Por me dar força em finalizar essa caminhada com honra e orgulho. E a Nossa Senhora que me carregou no colo quando faltaram forças, não permitindo que eu me desviasse do meu propósito. Abençoou-me. E me deu a graça da finalização dessa caminhada.

Agradeço meu pai Cícero. Fonte de inspiração e sabedoria. Minha fortaleza. Meu exemplo de vida. Meu herói. Meu amor infinito. Obrigada por estar sempre ao meu lado. Deus não poderia ter me dado um pai melhor.

Agradeço minha mãe Gisele. Fonte de fé, carinho, devoção e amor incondicional. Sem suas orações talvez essa etapa não terminaria com tanta glória. Obrigada por toda força e pelo exemplo de amor e família. O amor de filha é tão grande quanto o amor de mãe.

Ao meu filho... Meu Marianinho... Não há palavras para agradecer a sua existência e por fazer parte de um sonho que sempre almejei. Então agradeço a Deus por ter me tornado mãe de um ser tão amoroso, carinhoso, sorridente e abençoado. Meu coração será sempre seu e a conquista deste título é por você e para você. Te amo minha vida.

A minha querida Professora Dirce. Como agradecer tanto carinho e atenção? A senhora fez com que tudo se tornasse fácil e possível. Obrigada por ter caminhado comigo nesses últimos quatro anos e ter acreditado no meu potencial. Tenho certeza que daqui cresceu uma grande amizade.

A minha estrela guia Professora Ana Luiza. Impossível chegar aqui e não te agradecer. Hoje o que me tornei foi graças a você. Você me tornou uma pessoa melhor e assim serei eternamente grata. Você sempre me inspirou e me iluminou. Obrigada por tudo.

Agradeço a Professora Maria Rita, a Doutora Flávia Squinca e a Professora Fernanda Vinhaes por terem aceitado a participar da minha banca com tanta alegria.

Em especial agradeço ao Professor Pedro Sadi que em uma visita a Goiânia, sem me conhecer, reuniu-se comigo, me orientou e me inspirou em buscar pelo meu Mestrado e agora aqui faz parte do meu Doutorado. Obrigada Professor. O senhor é fonte de dedicação e amor ao que faz. 
Agradeço aos funcionários da Secretaria de Pós-Graduação em Ciências da Saúde, em especial a Edigrês pela sua disposição, carinho e atenção.

Por fim agradeço a minha família. Irmão Jerônimo, Cunhados (as) Eva, Mariano e Lívia, sobrinhos Enzo e Victor, Madrinha Geisa, tios, tias, primos (as), avó Celina e avô Albace (in memorian). E também aos meus amigos. Sei que mesmo longe ou perto todos sonharam, caminharam comigo. E intercederam por mim em meio a orações. Essa conquista sem vocês não seria tão gratificante. Obrigada por fazerem parte da minha vida. Amo todos vocês. 


\section{AGRADECIMENTO ESPECIAL}

Meu agradecimento mais profundo só poderia ser dedicado a uma pessoa: ao meu marido e eterno companheiro Rubens. O tempo todo ao meu lado. Sem você com certeza eu não conseguiria finalizar essa etapa tão almejada na minha vida. Sua sabedoria, luta e garra em buscar o melhor me inspira em continuar ao teu lado, buscando sempre, juntos, a nossa felicidade. Esse período nos mostrou a verdade sobre nosso relacionamento: somos uma Família. Sou grata por cada gesto carinhoso, cada sorriso, e ansiosa por estar ao seu lado, com nossos filhos, o resto de nossas vidas. Obrigada meu AMOR. Amo-te hoje e sempre. 
"Não importam as circunstâncias e não importam as adversidades, por mais difícil que seja eu vou seguir em frente e vou reunir todas as forças para que eu me transforme cada vez mais na pessoa que eu decidir ser". 
RESUMO

Introdução: Durante a formação acadêmica verifica-se a necessidade de compreensão sobre a ética e os princípios de bioética. O fisioterapeuta vivencia várias situações que têm implicações éticas e bioéticas e que são muito pouco conhecidas e discutidas. Portanto há uma preocupação com a preparação ética, bioética e moral do fisioterapeuta para o enfrentamento dos conflitos vivenciados no cotidiano da profissão. Objetivo: Analisar o perfil do ensino das disciplinas de ética e bioética nas universidades e centros universitários do Brasil que ofertam o curso de fisioterapia. Método: Estudo descritivo desenvolvido por meio de abordagem mista associada à revisão sistematizada da literatura. O período da realização foi de maio de 2013 a janeiro de 2015 e foi dividida em quatro etapas: I: Realização de revisão sistemática sobre o tema da bioética no contexto da formação acadêmica de profissionais da área da saúde; II: Produção de revisão sistemática sobre a disciplina de bioética no contexto da formação acadêmica do fisioterapeuta; III: Pesquisa através da identificação das Universidades e Centros Universitários que ofertam o curso de fisioterapia no Brasil; IV: Análise das matrizes curriculares e ou Projeto Pedagógico do curso de fisioterapia para identificar a presença das disciplinas de ética e ou deontologia e bioética. Resultado: Foram incluídas neste estudo 234 Instituições de Ensino Superior que ofertavam o curso de fisioterapia, onde somente $17(13,82 \%)$ apresentaram a disciplina de bioética em sua estrutura curricular e 62 (50,41\%) apresentaram a disciplina de ética e ou deontologia. A carga horária de 30 ou 40 horas prevaleceram nos resultados. Quanto a disciplina de bioética houve maior preocupação na abordagem temática e a disciplina de ética em sua maioria veio associada a deontologia. Conclusão: Com base nos resultados encontrados concluise que é necessária a expansão dos conteúdos de ética e bioética nos cursos de fisioterapia com ênfase na promoção de reflexão crítica por parte dos acadêmicos. Isso contribuirá para o enfrentamento de conflitos éticos, a construção autônoma de valores e conceitos, o que se refletirá em sua prática profissional.

Descritores: Ensino, Ética, Bioética, Fisioterapia, Instituições Acadêmicas 


\section{ABSTRACT}

Introduction: During the academic background, there is the need for understanding of the ethics and principles of bioethics. The physiotherapist experiences various situations that have ethical and bioethical implications, which are very little known and discussed. Therefore, there is a concern about ethics preparation, bioethics and moral Physiotherapist to face the current conflicts in the job routine. Aims: To analyze the profile of the teaching of Ethics and Bioethics courses in Universities and University of Brazil Centers that offer the course in Physical therapy. Methodology: Descriptive study developed through a mixed approach associated with the systematic review of the literature. The period of realization was May 2013 to January 2015 and was divided into four stages: I: Making a systematic review on the topic of bioethics in the context of academic education of health professionals; II: Making a systematic review of the bioethical discipline in the context of academic education of physiotherapists; III: Search by identifying the Universities and University Centers that offer the physiotherapy course in Brazil; IV: Analysis of curriculum matrices and / or Educational Project Physical therapy course to identify the presence of the subjects of ethics and / or ethics and bioethics. Results: We included in this study 234 higher education institutions that offered the course of Physical therapy, where only $17(13.82 \%)$ had the discipline of Bioethics in its curricular structure and 62 (50.41\%) presented the Ethics and Discipline / or ethics. The workload of 30 or 40 hours prevailed in the results. As for Bioethics course there was greater concern to address the subject and the subject of Ethics mostly came associated with ethics. Conclusion: Based on the findings it is concluded that the expansion of ethical content and bioethics in physiotherapy courses with emphasis on promoting critical reflection on the part of academics is required. This will contribute to confronting ethical conflicts, stand-alone building values and concepts, which will be reflected in their professional practice.

Key Words: Teaching, Ethics, Bioethics, Physical therapy, Schools. 


\section{LISTA DE FIGURAS}

FIGURA 1 - Fluxograma dos Métodos do Estudo..........................................48

FIGURA 2 - Fluxograma da Etapa I........................................................49 


\section{LISTA DE TABELAS}

TABELA 1 - Número por região de Universidades e Centros Universitários no Brasil que ofertam o curso de fisioterapia.

TABELA 2 - Número por estado de Universidades e Centros Universitários no Brasil que ofertam o curso de fisioterapia. 86

TABELA 3 - Natureza jurídica da Universidades e Centros Universitários no Brasil que ofertam o curso de fisioterapia .87

TABELA 4 - Total de períodos dos cursos de fisioterapia das Universidades e Centros Universitários no Brasil. .88

TABELA 5 - Semestre da disciplina de bioética. 89

TABELA 6 - Ementas da disciplina de bioética com a classificação das abordagens bioéticas seguindo o proposto por Costa e Diniz (2001). .90

TABELA 7 - Objetivos da disciplina de bioética. .92

TABELA 8 - Conteúdo programático da disciplina de bioética. 93

TABELA 9 - Referências da disciplina de bioética. 95

TABELA 10 - Semestre ao qual a disciplina de ética e ou deontologia é ministrada. 98

TABELA 11 - Relação das instituições que apresentam a disciplina de ética e ou deontologia e a ementa .99

TABELA 12 - Descrição das instituições e o conteúdo programático abordado nas disciplinas de ética e ou deontologia. 105

TABELA 13 - Descrição das instituições e as referências bibliográficas das disciplinas de ética e ou deontologia 
LISTA DE ABREVIATURAS E SIGLAS

ABBR: Associação Brasileira Beneficente de Reabilitação

ABENFISIO: Associação Brasileira de Ensino em Fisioterapia

CNE: Conselho Nacional de Educação

CNPq: Conselho Nacional de Desenvolvimento Científico e Tecnológico

COFFITO: Conselho Federal de Fisioterapia e Terapia Ocupacional

CREFITO: Conselho Regional de Fisioterapia e Terapia Ocupacional

DCN: Diretrizes Curriculares Nacionais

ERRJ: Escola de Reabilitação do Rio de Janeiro

INAR: Instituto Nacional de Reabilitação

MEC: Ministério da Educação e Cultura

SINFITO: Sindicato dos Fisioterapeutas e Terapeutas Ocupacionais

SUS: Sistema Único de Saúde 


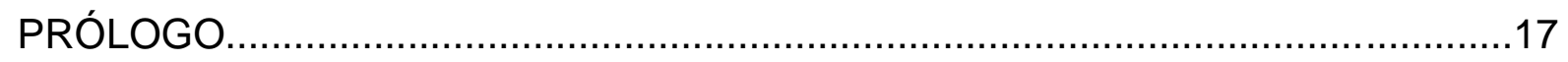

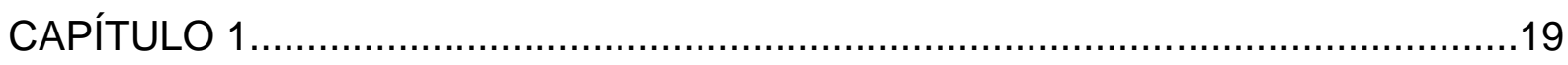

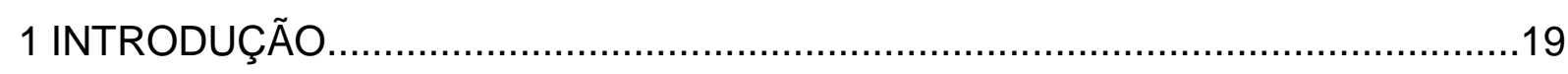

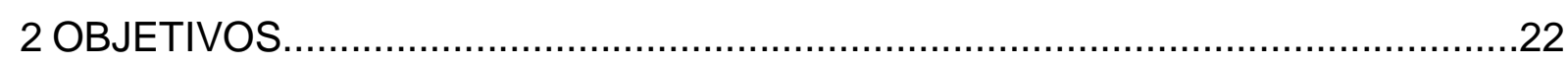

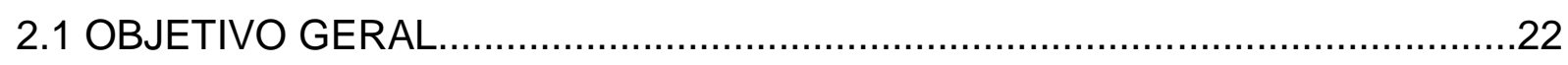

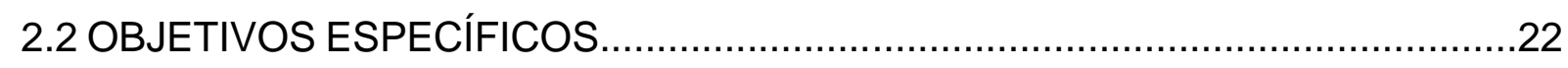

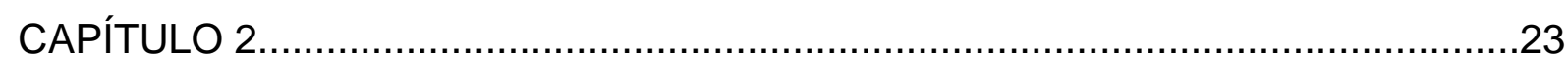

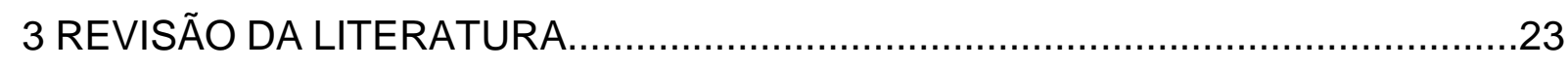

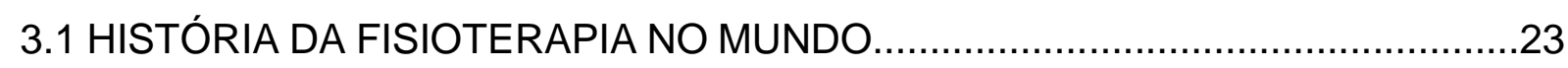

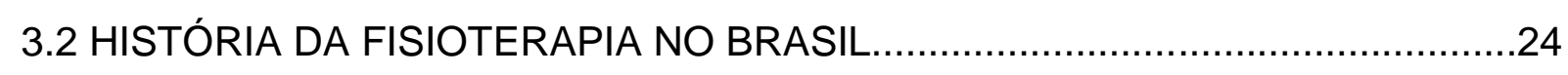

3.3 HISTÓRIA DO CURSO DE FISIOTERAPIA NO BRASIL....................................26

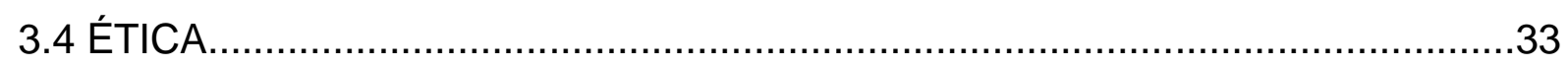

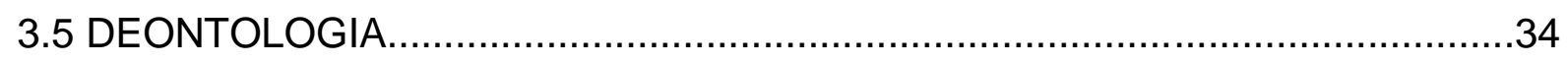

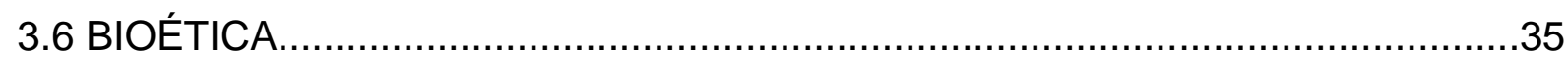

3.7 DIRETRIZES CURRICULARES E A INTRODUÇÃO DA BIOÉTICA NAS MATRIZES CURRICULARES DO CURSO DE FISIOTERAPIA..............................40 3.8 AS DISCIPLINAS DE ÉTICA E OU DEONTOLOGIA E BIOÉTICA NA FORMAÇÃO

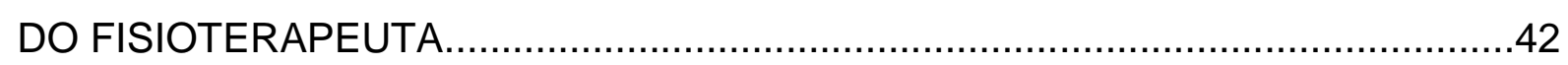

3.9 A IMPORTÂNCIA DA BIOÉTICA NA FORMAÇÃO DO FISIOTERAPEUTA........43

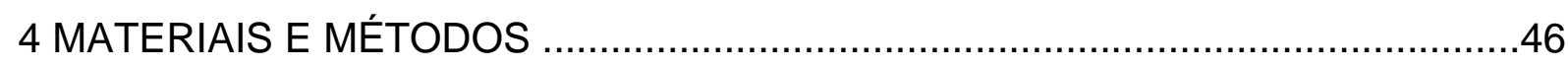

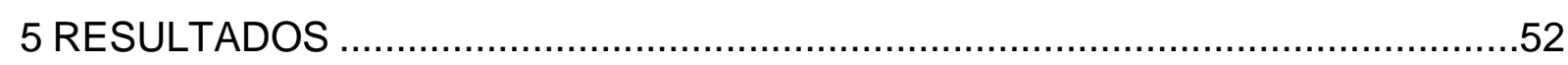

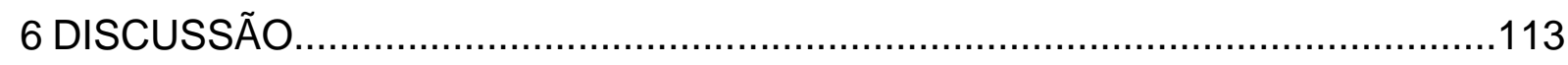

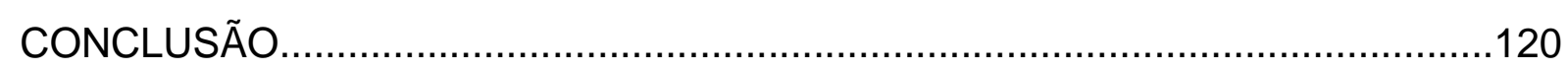

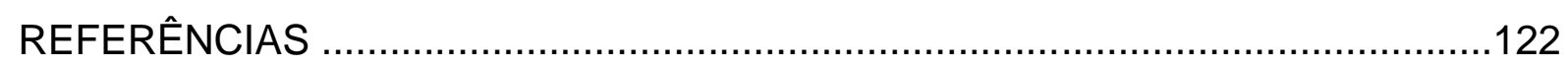

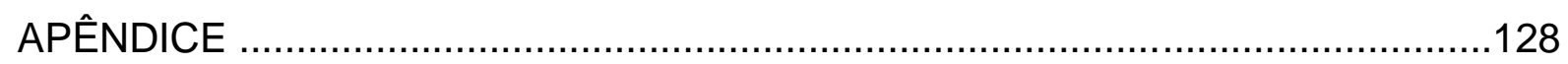




\section{PRÓLOGO}

Há aproximadamente cinco anos, fui convidada para ser coordenadora de um curso de fisioterapia em uma Instituição de Ensino Superior em Goiás. Neste cargo eu teria por obrigatoriedade ministrar uma disciplina chamada "Introdução a Fisioterapia e Bioética" no primeiro período do curso. Na mesma época ocorreu a saída de um professor da instituição e fui indicada para substituí-lo na disciplina de "Bioética" no quarto período do curso de nutrição.

As duas ementas de bioética abordavam apenas temas como fim da vida, eutanásia, aborto, clonagem, religião, transfusão sanguínea, dentre outros temas da atualidade, mas com pouco vínculo com a prática profissional. A disciplina do curso de fisioterapia era ainda mais restrita porque a carga horária era compartilhada por questões vinculadas à fisioterapia e por alguns temas de bioética.

Além disso, com visão de administradora, fui observando dificuldades nos relacionamentos interpessoais entre alunos, aluno-professor e principalmente alunopaciente. Havia neles um medo extremo de lidar com os pacientes. Esse medo não estava relacionado aos tratamentos que deveriam ser ofertados, mas sim à forma como seriam tratados pelos pacientes. Como detectar, por exemplo, atitudes que se caracterizariam como assédio, desrespeito, palavras desnecessárias. O contato físico é inerente ao trabalho do fisioterapeuta e isso também pode trazer questões clínicas e éticas importantes.

Em algumas ocasiões tive que lidar com dificuldades de relacionamentos entre alunos, entre alunos e professores e entre professores. A partir daquele momento e das reflexões sobre o que ocorria que me surgiu a seguinte pergunta: os alunos estão sendo preparados para atuar de forma ética? E como a bioética entra nesse processo? A formação acadêmica tem papel fundamental na construção da identidade e dos comportamentos que serão adotados pelo futuro profissional.

Foi assim que me aproximei da Professora Dirce Guilhem, que havia participado da minha banca de Mestrado, aqui mesmo no Programa de PósGraduação em Ciências da Saúde, e perguntei-lhe se seria interessante desenvolvermos um projeto sobre a disciplina de bioética nos cursos de Graduação de fisioterapia. Ela prontamente aceitou e me estimulou a elaborar o projeto do doutorado e participar da seleção. Sei que estava fugindo da área da minha especialidade e da área do meu mestrado, mas a partir desse momento me vi como 
docente preocupada com as atitudes do profissional que eu estava ajudando a formar. Senti-me responsável por isso.

Inicialmente, tínhamos a proposta de desenvolver um projeto para questionar os alunos sobre possíveis conflitos pessoais e profissionais que os mesmos enfrentavam durante a formação acadêmica e como a disciplina de bioética contribuiria para a vida profissional deles. Entretanto, como o futuro a Deus pertence, o destino me trouxe para Brasília, onde precisei alterar o objeto de estudo para uma análise nacional da disciplina.

Hoje, espero com este estudo, contribuir para que as Instituições de Ensino Superior vejam a necessidade do estudo da bioética de forma independente (ou seja, sem vinculá-lo a outros conteúdos), a necessidade de abordagem direcionada para promoção da reflexão não apenas sobre temas pontuais. É preciso ter olhar atento para as necessidades que emergem da prática clínica cotidiana. Acredito que a bioética é, portanto, fundamental para a formação do estudante, pois fornece base sólida sobre a adoção de atitudes éticas. Nunca esquecendo, porém, que o agir bioético cristaliza o agir mais humano, tornando-nos aptos para o enfrentamento dos conflitos subjacentes ao dia-a-dia da nossa profissão. 


\section{CAPÍTULO 1}

\section{INTRODUÇÃO}

A partir da década de 1980, a atuação do fisioterapeuta sofreu um processo de transformação e os profissionais passaram a incorporar novos campos de trabalho, que incluíam a promoção e a prevenção da saúde. Devido a isso, em 1983, por meio da Resolução ํo 4 do Conselho Federal de Educação, foi criado o currículo mínimo para o curso de graduação em fisioterapia, no qual a disciplina de ética e deontologia era obrigatória ${ }^{1}$.

Historicamente a formação do profissional em fisioterapia não apresentava familiaridade com a Filosofia, que é uma área que permite discussões sobre ética e bioética, tornando essa formação tecnicista e pouco humanista. Portanto, observa-se que há uma maior importância de estabelecer uma reflexão sobre o tema na formação acadêmica, já que a ética está presente na prática profissional².

Durante a formação acadêmica verifica-se a necessidade de compreensão sobre a ética e os princípios de bioética e, ainda, de se conhecer o conceito que está representado na mente do aluno, para avaliar e diagnosticar o nível de compreensão sobre o assunto. A bioética como disciplina também pode auxiliar no enfrentamento de situações de difícil mediação moral como o fim da vida, a morte, a negligência, o aborto, dentre outras. Isso justifica o fato das duas disciplinas serem essenciais em todos os anos da formação acadêmica ${ }^{3,4,5,6}$.

Diante disso, em 2002, foram aprovadas as novas diretrizes curriculares do curso de fisioterapia, por meio do Parecer do Conselho Nacional de Educação no 1.210/2001. Neste novo contexto, o perfil do egresso passou a contemplar uma formação generalista, humanista, crítica e reflexiva, respeitando os princípios éticos/bioéticos, e culturais do indivíduo e da coletividade?

O fisioterapeuta vivencia várias situações que têm implicações éticas e bioéticas e que são muito pouco conhecidas e discutidas. As preocupações incluem a dificuldade de definição do tratamento fisioterapêutico e dos seus resultados, a proximidade na interação entre terapeuta e paciente durante os atendimentos, a relação profissional/paciente quanto ao princípio de autonomia, a falha comum nos 
encaminhamentos dos pacientes para a reabilitação e o conflito ético do atendimento desses $\operatorname{casos}^{8,9,10}$.

Durante a etapa de levantamento bibliográfico para a fundamentação teórica deste estudo, foram encontrados poucos trabalhos relacionados a importância da disciplina de bioética para os graduandos em fisioterapia. Acredita-se que existam muitos outros trabalhos que relacionem a ética e bioética com a fisioterapia, mas que não foram publicados ou encontravam-se em revistas não indexadas. Esta é uma área ainda pouco explorada no Brasil. Entre as profissões de saúde, há pouco ou quase nenhum interesse filosófico. $E$ isso é surpreendente, porque algumas das características marcantes daqueles que lidam com o cuidar humano são exatamente os princípios relacionados à ética e bioética ${ }^{8,11}$.

Entretanto, foi possível observar em estudos já publicados a preocupação com a preparação ética, bioética e moral do fisioterapeuta para o enfrentamento dos conflitos vivenciados no cotidiano da profissão. Essas reflexões apontam para a necessidade de se criar linhas de pesquisa na interseção entre a ética e ou bioética e a fisioterapia. No momento da vivência clínica, questões de caráter ético e ou bioético são comuns entre fisioterapeutas e a possibilidade de disseminar esses conhecimentos pode ajudar no preparo de outros profissionais para uma atuação mais responsável e humanizada.

O Código de Ética Profissional de Fisioterapia e Terapia Ocupacional (RESOLUÇÃO №. 10, DE 03 DE JULHO DE 2013) estabelece responsabilidades fundamentais e normativas com relação ao exercício profissional e a disposições gerais ${ }^{12,13}$. Como agentes morais, os fisioterapeutas são compelidos a tomar suas próprias decisões clínicas e éticas com base em conexões e relações com seus pacientes, outros membros da equipe multiprofissional de saúde, instituições de saúde, em consonância com políticas públicas relacionadas à saúde e aos direitos fundamentais ${ }^{9}$.

Diante do exposto, o Código de Ética Profissional é a base para a boa conduta e o requisito mínimo para incorporação dos valores da profissão, porém acredita-se que ele não seja suficiente para resolver os conflitos éticos. Os Códigos de Ética costumam ser mais deontológicos, normatizadores, servem como norteadores de condutas e não conseguem dar conta de uma série de dilemas éticos que surgem no dia-a-dia. Com o avanço da tecnologia, a bioética então se defronta todos os dias com novos problemas. 
Dessa forma, emergiram, então, as seguintes questões norteadoras: Como se constitui o perfil das disciplinas de ética, deontologia e bioética nas instituições de Ensino Superior que ofertam o curso de fisioterapia no Brasil? Qual o referencial bioético que está sendo majoritariamente incorporado ao ensino? E qual o referencial ético? Esse é um tema pouco explorado e, para responder essas questões, o objetivo desta pesquisa foi o de analisar o perfil das disciplinas de ética, deontologia e bioética ministradas nas Universidades e Centros Universitários no Brasil que possuem o curso de fisioterapia. 


\section{OBJETIVOS}

\subsection{OBJETIVO GERAL}

- Analisar o perfil do ensino das disciplinas de ética, deontologia e bioética nas Universidades e Centros Universitários do Brasil que ofertam o curso de fisioterapia.

\subsection{OBJETIVOS ESPECÍFICOS OU SECUNDÁRIOS}

- Realizar revisão sistematizada sobre o tema da bioética no contexto da formação acadêmica de profissionais da área da saúde e, em especial, da fisioterapia.

- Apresentar o panorama de inserção curricular das disciplinas de ética e ou deontologia e bioética nos cursos de fisioterapia das Universidades e Centros Universitários no Brasil.

- Descrever o perfil das disciplinas de bioética ministradas no curso de fisioterapia pelas Universidades e Centros Universitários no Brasil mediante análise das ementas e identificação das linhas teóricas e temáticas predominantes nessas abordagens.

- Identificar se os docentes que ministram as disciplinas de ética e ou deontologia e bioética no curso de fisioterapia apresentam trajetória acadêmica com os temas em questão.

- Analisar o referencial bibliográfico utilizado para ministrar as disciplinas de ética e ou deontologia e bioética para o curso de fisioterapia. 


\section{CAPÍTULO 2}

\section{REVISÃO DA LITERATURA}

\subsection{HISTÓRIA DA FISIOTERAPIA NO MUNDO}

Na Antiguidade, período entre 4000 a.C. e 395 d.C. havia uma preocupação constante em tratar e curar as enfermidades e aliviar a dor através da utilização de agentes físicos como o sol, o calor, a água e a eletricidade (utilização de choques com peixe elétrico), e massagens e exercícios físicos. Nessa época a utilização da ginástica era somente para fins terapêuticos, ou seja, era utilizada no tratamento de pessoas com disfunções orgânicas já instaladas ${ }^{8,14}$.

$\mathrm{Na}$ Idade Média (período entre os séculos IV e XV) a fisioterapia curativa sofreu uma interrupção no avanço dos estudos e da atuação na área da saúde, pois nessa época havia maior interesse pelo desenvolvimento da capacidade física pelas classes mais privilegiadas. Após esse período de estagnação dos estudos, surge o Renascimento (séculos XV e XVI) onde o interesse não se destina apenas a concepção curativa (preocupação com o tratamento e os cuidados com o organismo lesado), mas também a manutenção do corpo saudável8.

Entre os séculos XVIII e XIX ocorre com a industrialização o desenvolvimento das cidades e assim começaram a surgir condições sanitárias e alimentares insatisfatórias, jornadas de trabalho abusivas de mais de 16 horas, o trabalho infantil e exploração dos operários e camponeses pela classe dominante ${ }^{14}$. Isto predispôs a proliferação de novas doenças, fazendo surgir novas enfermidades e epidemias como a cólera, tuberculose pulmonar, alcoolismo e os acidentes de trabalho que obrigaram a medicina a voltar a sua atenção ao tratamento e sequelas ${ }^{8}$.

Além do aparecimento de novas doenças relativas ao desgaste das estruturas corporais, pelas excessivas exigências do período industrial, as guerras também contribuíram para a consolidação do exercício fisioterapêutico, pois produziram um grande contingente de pessoas que precisavam de tratamento para se recuperar ou reabilitar e readquirir um mínimo de condições para voltar a uma atividade social integrada e produtiva ${ }^{15}$. Dessa forma, a aplicação de recursos elétricos, térmicos e 
hídricos e a aplicação de exercícios físicos sofreram uma evolução totalmente voltada para o atendimento do indivíduo doente ${ }^{8}$.

Foi com a Revolução Industrial que foram desenvolvidos trabalhos para recuperar os trabalhadores acidentados. Outro objetivo, nesta época, foi de criar diferentes tipos de ginástica e exercícios que tinham como finalidade aumentar a produtividade nas indústrias ${ }^{14}$.

Ainda no século XIX, surgem então as especializações médicas, onde a fisioterapia parece ter seguido a mesma direção dividindo-se em diferentes áreas de atuação. No decorrer da história percebe-se que a profissão sofreu todas essas oscilações, passando pela atuação curativa na antiguidade, pela estagnação na ldade Média, pela atenção preventiva concomitante a curativa durante o Renascimento e novamente pelo direcionamento puramente curativo durante a industrialização. $E$ foi durante a Segunda Guerra Mundial que surgiram as escolas de Cinesioterapia para tratar e reabilitar os lesionados ou mutilados que necessitavam readquirir condições para retornar as suas atividades de vida diária ${ }^{8}$.

\subsection{HISTÓRIA DA FISIOTERAPIA NO BRASIL}

A história da fisioterapia no Brasil inicia com a Fuga da Família Real Portuguesa para o Brasil, em 1808, pois junto vieram também recursos humanos e financeiros para atender às necessidades dos nobres e monarcas que se instalaram neste país. Dessa forma, criaram-se duas primeiras escolas de medicina brasileira na Bahia e no Rio de Janeiro (hoje conhecida como Faculdade de Medicina da Universidade Federal do Rio de Janeiro) no mesmo ano. Foi a partir da formação dos primeiros médicos brasileiros que começaram a surgir os primeiros serviços de fisioterapia no Brasil ${ }^{14}$.

Os primeiros serviços de hidroterapia e eletricidade médica surgiram por volta dos anos de 1879 a 1883. Logo após, em 1884 houve a criação do serviço de fisioterapia no Hospital de Misericórdia do Rio de Janeiro. E alguns anos depois, em 1919, em São Paulo, o médico Raphael Penteado de Barros fundou o departamento de eletricidade médica ${ }^{16}$.

O fato mais interessante na história da fisioterapia brasileira, na virada do século XIX para o século $X X$, foi a importância que os profissionais médicos depositavam sobre esta área de conhecimento, o que de fato permitiu verdadeiras disputas pelo conhecimento e domínio da fisioterapia. Isto se comprova nos registros 
médicos do Dr. Álvaro Alvim que se auto intitulava "electrotherapeuta", além do seu livro intitulado "Physicotherapia - A Electricidade perante a medicina" publicado em 1902. O médico Adolpho Gomes Pereira neste mesmo ano defendeu sua tese intitulada "Physiotherapia", apresentada para a obtenção do título de Doutor na cadeira de Therapeutica pela Faculdade de Medicina do Rio de Janeiro ${ }^{14,16}$.

Pode-se observar então que, no Brasil, desde muito cedo, a fisioterapia foi área de interesse de outras categorias profissionais e com a criação das primeiras escolas de formação de fisioterapeutas, na década de 50 , foram surgindo os profissionais que iriam se responsabilizar por tão nobre área de estudo e atuação. No entanto, a maioridade técnico-científica e consequente autonomia do fisioterapeuta tiveram inúmeros obstáculos em seu caminho rumo à consolidação. Mesmo depois do reconhecimento legal do profissional fisioterapeuta, em 13 de outubro de 1969, a fisioterapia foi palco de disputas intensas no chamado "mercado de saúde" brasileiro ${ }^{14}$.

Alguns autores associam a alta incidência da poliomielite com a ascensão da profissão da fisioterapia na década de 50 . Foi assim que surgiram diversos serviços de fisioterapia no Brasil, como a Sociedade Pestalozzi (1945); a APAE carioca (Associação de Pais e Amigos do Excepcional em 1954); o Instituto Baiano de Fisioterapia (1955); o Centro de Reabilitação Sara Kubitschek em 1960; a Associação Beneficente Cearense de Reabilitação (1966). Essa doença trouxe como consequência morte, sofrimento e inúmeros indivíduos portadores de sequelas motoras que necessitavam de reabilitação para retornar as suas atividades diárias ${ }^{14,16}$.

Como os fisioterapeutas ofereceram seus serviços no tratamento e contribuíram para a pesquisa e diminuição da mortalidade nos pacientes de poliomielite, o contato com a doença e suas características clínicas peculiares permitiu grandes avanços clínicos na área da fisioterapia. Esses avanços marcam até hoje a atuação desses profissionais ${ }^{16}$.

A fisioterapia também surgiu como forma de solução para os altos índices de acidentes de trabalho no Brasil que era considerado um dos mais elevados da América do $\mathrm{Sul}^{8}$. Dessa forma, pode-se observar que primeiramente a prática profissional foi instituída, para posteriormente obter-se o reconhecimento dos cursos de formação e o reconhecimento da profissão ${ }^{15}$. 


\subsection{HISTÓRIA DO CURSO DE FISIOTERAPIA NO BRASIL}

A modernização das escolas médicas e o caráter científico e especializado das práticas de saúde talvez tenham constituído os primeiros passos para o reconhecimento legal da fisioterapia, enquanto profissão no Brasil, já que a utilização de recursos físicos na assistência à saúde já era praticada desde 1879. Tal fato implicou no desenvolvimento da formação de recursos humanos, surgindo em 1951 o primeiro curso de formação de técnicos em fisioterapia na Universidade de São Paulo, acessível a alunos com segundo grau completo, que durou até 1956. Estes profissionais eram denominados fisioterapistas ${ }^{15}$.

O surgimento da Associação de Assistência à Criança Defeituosa, do Lar Escola São Francisco e das Casas da Esperança, absorveu esse novo conceito de assistência diferenciada incorporando, em seu meio, os profissionais técnicos formados pelos novos cursos. As primeiras turmas de técnicos de reabilitação formaram profissionais que se inseriram nos consultórios e clínicas auxiliando os médicos, que prescreviam os exercícios, as massagens, o uso do calor, da luz, dos banhos e dos rudimentares recursos eletroterápicos disponíveis para a recuperação do paciente. Diferentemente dos países da Europa, como na França que em 1927 já possuía curso de graduação em fisioterapia, no Brasil o ensino de fisioterapia restringia-se a aprender ligar e desligar aparelhos, reproduzir mecanicamente ${ }^{15}$.

A partir de 1959 houve modificações na realização do curso de formação profissional e o mesmo passou então a formar fisioterapeutas no Instituto Nacional de Reabilitação, anexo à Cadeira de Ortopedia e Traumatologia da Faculdade de Medicina da Universidade de São Paulo. Tal curso teria duração de dois anos para formar fisioterapeutas técnicos que atuassem em reabilitação.

Enquanto isso, em 1954 foi criada a Associação Brasileira Beneficente de Reabilitação (ABBR). E em 1957 foi inaugurado o Centro de Reabilitação da ABBR pelo Presidente da República Juscelino Kubitscheck que teve seu crescimento e desenvolvimento devido ao esforço pessoal e batalhador de Fernando Lemos (fundador da ABBR) que lutou no tratamento do seu único filho de 15 anos, vítima de poliomielite ${ }^{16,18,19}$.

Logo após a cerimônia de fundação da ABBR em 1954, o seu conselho médico decidiu fundar a Escola de Reabilitação do Rio de Janeiro (ERRJ). Essa foi a primeira instituição a formar fisioterapeutas em nível superior no Brasil. No dia 3 de abril de 
1956 foi realizada a cerimônia de abertura do período letivo, com a presença dos primeiros alunos e professores dos cursos de fisioterapia e terapia ocupacional, que iniciavam conjuntamente a sua profissão. Embora a Escola tenha iniciado os trabalhos no ano de 1956, o Ministério da Educação reconheceu os diplomas dos primeiros formados (ao total 16 fisioterapeutas) pela ERRJ somente em 1965 depois de um longo processo ${ }^{16}$.

Em São Paulo, em 1958, foi iniciado um novo curso de formação na área da fisioterapia, no Instituto Nacional de Reabilitação (INAR) ligado à Universidade de São Paulo. A primeira turma, do INAR, formou no final de 1959 após conclusão de um curso regular de dois anos de duração ${ }^{16}$.

Nos anos cinquenta, a atuação profissional estava diretamente ligada a reabilitação com o objetivo de recuperar a função perdida, recuperar o incapacitado, o mutilado, com recursos que na época baseavam-se em massagem, ginástica e eletroterapia. Além disso, o curso era classificado quanto a sua importância social abaixo do nível do curso de medicina e acima dos cursos de enfermagem e educação física. O professor Antônio Caio na época ressaltou que o reabilitador não é um médico e que a Medicina física foi dividida em duas partes: a diagnóstica e a terapêutica. Dessa forma a diagnóstica era exclusiva da atuação médica e os reabilitadores ficariam com a terapêutica ${ }^{16}$.

Havia na época um documento muito importante: o Código de Ética do Técnico em Reabilitação da ABBR. Dos dezoito itens que descreviam os princípios gerais, nove deles expressavam proibições ou relações de dependência com o médico. Também pedia que o profissional esforçasse por sempre aprimorar seus conhecimentos e que teria a obrigação de garantir o maior bem-estar do paciente. Haviam itens muito bem demarcados como aplicar técnicas profissionais somente sob específicas e adequadas orientações médico; em momento algum o técnico deveria assumir responsabilidades de diagnóstico e prescrição do tratamento das lesões; o mesmo só poderia iniciar o tratamento após obter do médico informações precisas sobre o diagnóstico; o técnico não poderia realizar nenhum tratamento além da data marcada pelo médico e receberia do mesmo instruções sobre o término do tratamento; o técnico evitaria atitudes que poderiam ser interpretadas pelo paciente como críticas ao médico; somente o médico poderia informar o prognóstico; a clientela dos técnicos só poderia ser constituída de pacientes encaminhados por médicos, sendo proibida a publicidade; e em hipótese alguma o técnico poderia ministrar o ensino da reabilitação 
individualmente. É possível dessa forma, observar a preocupação em restringir a atuação do fisioterapeuta em relação à atuação dos médicos ${ }^{16}$.

O currículo oferecido para a formação dos fisioterapeutas na ERRJ sofreu diversas alterações desde a sua concepção em 1956 até o reconhecimento do curso em 1965. Em 1957, o Manual do Aluno definia o curso como de nível universitário, com três anos de duração e em horário integral. As disciplinas fundamentais e as clínicas ofertadas no primeiro ano do curso eram: anatomia descritiva, cinesiologia clínica, massoterapia, termoterapia, patologia médica, psicologia aplicada à reabilitação, fundamentos da reabilitação, clínica ortopédica e clínica traumatológica. No segundo ano eram: anatomia descritiva, fisiologia humana, cinesiologia clínica, cinesioterapia, hidrobalneoterapia, crenoclimatoterapia, psicopatologia, clínica médica, clínica neurológica, clínica reumatológica e clínica psicossomática ${ }^{16}$. Dessa forma, pode-se observar que não existia na época uma disciplina específica para o estudo da ética e ou deontologia.

Em 1963, um novo Projeto Lei ( $n^{\circ}$ 1.372) definiu uma carga horária mínima de formação do fisioterapeuta que deveria compor 2500 horas, sendo 1000 horas de aulas teórico-práticas e 1500 horas de estágio, porém, em 1967 este Projeto foi arquivado $^{16}$.

Foi com o Parecer N. 388/63 elaborado pelo Conselho Federal de Educação, aprovado em 1963 pelo Ministério de Educação e Cultura (MEC), que houve o reconhecimento do curso de fisioterapia. Deveria ter a duração de três anos e um currículo mínimo, porém definiu o fisioterapeuta como técnico e auxiliar do médico, limitando sua prática às recomendações médicas ${ }^{20}$.

Em 1964, a atuação dos técnicos em fisioterapia foi ampliada para a função de fisioterapeuta, como profissionais de curso superior, porém suas atividades ainda se limitavam à execução das técnicas de massagens e exercícios e à aplicação de aparelhos, sob prescrição médica. Entretanto, alguns anos depois, em 13 de outubro de 1969, com o Decreto-Lei №. 938/1969, foram oficialmente reconhecidas as profissões de fisioterapia e Terapia Ocupacional como nível superior. A atividade privativa do Fisioterapeuta era a de executar métodos e técnicas fisioterapêuticas com a finalidade de restaurar, desenvolver e conservar a capacidade física do paciente ${ }^{16,21}$.

Até 1969 existiam apenas cinco instituições que formavam fisioterapeutas no país que estavam localizadas nos Estados de São Paulo, Rio de Janeiro, Minas Gerais, Bahia e Pernambuco. Todas estavam ligadas diretamente a centros de 
Reabilitação, porém, do ponto de vista administrativo, eram subordinadas às Faculdades de Medicina (exceto a ERRJ). Quanto ao corpo docente, 95\% pertenciam a classe médica, a direção era de responsabilidade de médicos ortopedistas ou com experiência em reabilitação ${ }^{17}$.

Através da Lei 6.316, de 17 de dezembro de 1975, a profissão estava devidamente regulamentada e a partir desse momento iniciou-se o processo de criação dos Conselhos Federal e Regionais de Fisioterapia e Terapia Ocupacional com a função de normatizar e fiscalizar o exercício profissional da fisioterapia em todo o país. Em 1978 foram criados os três primeiros Conselhos Regionais, com sede em São Paulo, Rio de Janeiro e Recife. Ainda neste mesmo ano o COFFITO (Conselho Federal de Fisioterapia e Terapia Ocupacional) publicou diversas Resoluções como a COFFITO 08 que aprovou as normas para habilitação ao exercício das profissões e a COFFITO 10 que criou o Código de Ética Profissional ${ }^{16}$.

A Resolução COFFITO 8 tornou privativos dos fisioterapeutas a direção e responsabilidade técnica dos serviços e locais destinados a atividades fisioterápicas, assim como supervisão, avaliação, reavaliação, prescrição, indução de tratamento e alta do cliente submetido à fisioterapia. Ampliou a área de atuação profissional para escolas, creches, indústrias, entre outras, tornando também privativos dos fisioterapeutas a elaboração de testes específicos para avaliar níveis de capacidade funcional, prescrição e programação das atividades de vida diária, prescrição e adaptação de órteses e próteses funcionais, orientação familiar referente aos padrões funcionais dentre outros ${ }^{16}$.

O crescimento da profissão aumentou as diferenças entre os fisioterapeutas e os médicos vinculados à reabilitação e acarretou um conflito profissional de grande magnitude. Como consequência, a Associação Médica Brasileira reconheceu a fisiatria como especialidade médica. Um autor que informa que esta especialidade foi reconhecida em 1954, outro em 1972 durante o processo de reconhecimento da profissão de fisioterapia. Nos Estados Unidos, a fisiatria foi criada em 19476,16.

O Código de Ética Profissional de Fisioterapia e Terapia Ocupacional foi então criado em 1978 e aprovado pela Resolução COFFITO 10 de 3 de julho de 1978 no qual estabelecia as responsabilidades e normas para o exercício profissional. Ficou em vigor até 2013 (35 anos), quando foi reestruturado. É importante ressaltar que a Fisioterapia e a Terapia Ocupacional ficaram juntas no mesmo conselho porque o número de fisioterapeutas da época era insuficiente para criar um Conselho, sendo 
necessário a união de ambas as profissões para que o mesmo fosse aprovado. Somente em 12 de agosto de 1980 foi expedida carta sindical, pelo Ministério do Trabalho, reconhecendo o sindicato representante dos fisioterapeutas e terapeutas ocupacionais (SINFITO), que veio para "defender os interesses trabalhistas da classe"21.

Mesmo após o reconhecimento da profissão, ainda era necessário completar a infraestrutura profissional e reavaliar as áreas de ensino ${ }^{6}$. Foi apenas em 1983 que o MEC aprovou um novo currículo mínimo para o curso de fisioterapia, com 3.240 horas com mínimo de quatro anos e máximo de oito de duração (Resolução oㅜ 4, de 28 de fevereiro de 1983)22. Este currículo esteve vigente até o ano de 2001 (embora na prática até hoje matrizes curriculares ainda sejam baseadas neste modelo) quando foi substituído pelas Diretrizes Curriculares Nacionais em Fisioterapia e privilegiou aspectos antes esquecidos, como por exemplo as matérias de formação geral que incluem: Sociologia, Antropologia, Psicologia, Saúde Pública, Metodologia de Pesquisa, além de enfatizar os conteúdos específicos da área e os de fundamentação. Considerando a grande expansão do campo de atuação, muitas escolas já vinham adaptando o seu currículo e a disciplina de ética e deontologia faziam parte do ciclo de matérias essenciais para a formação geral do fisioterapeuta ${ }^{16,17}$.

A fisioterapia brasileira, além de ser uma profissão nova legalmente, é mais nova ainda como conhecimento científico. Somente 14 anos atrás foi inserida na comunidade científica brasileira. Entretanto, nesse pouco tempo já tomou medidas para assegurar a participação contínua no meio científico, a melhor qualificação de profissionais e, fundamentalmente, o reconhecimento da importância da profissão junto ao Estado e a sociedade ${ }^{23}$.

Devido ao modelo curativo de atenção à saúde desenvolvido no país no período militar e à ausência de regulamentação curricular na década de 1970, a fisioterapia consolidou-se como profissão reabilitadora e direcionou-se para o nível terciário. No que diz respeito ao desenvolvimento e reconhecimento pelas demais profissões da área de saúde, esse período constituiu-se como alicerce para valorização e reconhecimento dos benefícios e das potencialidades da profissão junto à equipe de saúde. E foi com o estabelecimento do currículo mínimo para a formação em fisioterapia (Brasil, 28 fev. 1983) que reforçou a posição da profissão de se pautar pelo modelo curativo-reabilitador ${ }^{24}$. 
A década de 1990 se caracterizou principalmente por uma série de resoluções importantes emanadas do COFFITO, legislações oriundas dos governos federal e estaduais, em especial do Ministério da Saúde com relação à fisioterapia. Esta quantidade de resoluções, portarias e decretos vinham consolidando o campo assistencial da fisioterapia, cada vez mais, e em verdade, reconhecendo legalmente, o que o fisioterapeuta já fazia, na prática, há anos atrás. Ideologicamente, a fisioterapia buscava cada vez mais seu afastamento do chamado processo de reabilitação, caminhando em direção ao campo da saúde em toda a sua plenitude ${ }^{14}$.

Nos anos 1990 iniciou-se também a expansão do número de cursos de fisioterapia no Brasil. Quanto ao modelo de formação, entretanto, as instituições de ensino mantiveram e aprofundaram o curativo-reabilitador privatista, formando fisioterapeutas a partir da concepção de profissional liberal. Estimulou-se o aprimoramento tecnicista sob o discurso da crescente concorrência do mercado de trabalho, em que o domínio do conhecimento biológico e das técnicas de reabilitação era requisito suficiente e necessário para o estabelecimento no mercado ${ }^{24}$.

A ampliação do número de cursos e vagas também ocorreu de forma desregulada, desencadeando os problemas referidos. Os cursos de fisioterapia expandiram-se sem planejamento e regulação, em meio à estagnação das instituições de ensino superior públicas e ao incentivo às instituições privadas. A abertura de novos cursos atingiu acelerada expansão a partir de 1997, porém de forma desregulada, com privatização do ensino e concentração geográfica dos cursos na Região Sudeste. Porém, a ampliação do número de cursos e a maior oferta de profissionais não resultaram em maior acesso da população à assistência em fisioterapia. O modelo da formação adotado tem sido o curativo-reabilitador privatista, inadequado à nova realidade epidemiológica e ao atual modelo de atenção à saúde ${ }^{24}$.

Em 1999 devido a necessidade de desenvolvimento e o aprimoramento do ensino/formação em fisioterapia houve a criação da Associação Brasileira de Ensino em Fisioterapia (ABENFISIO). Esta entidade congrega docentes, discentes e coordenadores de cursos de graduação, que se aprofundam em debates sobre a formação em fisioterapia. A entidade, até hoje, promove semestralmente fóruns nacionais de discussão a respeito do ensino da fisioterapia, nos quais se realizam avaliações e se discutem a qualidade do ensino e o modelo de formação. Também são estruturadas novas propostas e abordagens de ensino, com formação 
fundamentada nos princípios do SUS (Sistema Único de Saúde) e articulada com os saberes da saúde coletiva ${ }^{24}$.

Com relação à natureza administrativa das instituições de ensino, verifica-se que a expansão da fisioterapia ocorreu majoritariamente a partir da iniciativa privada. Em 1995, dos 63 cursos existentes, 46 (73\%) eram da rede privada e 17 (27\%), da rede pública. Em 2003, esses números eram 263 (88,2\%) e 35 (11,8\%), respectivamente, demonstrando a tendência à privatização do ensino da fisioterapia ${ }^{25}$. Embora se deva destacar que a rede pública ampliou o número de cursos em mais de $100 \%$ no período observado, o aumento se apresenta de forma muito mais expressiva na rede privada ${ }^{24}$.

Em 2003, a distribuição de cursos era de 181 (60,7\%) na região Sudeste; 57 $(19,1 \%)$ na região Sul; $17(5,8 \%)$ na região Centro-Oeste; $35(11,7 \%)$ na região Nordeste; e oito $(2,7 \%)$ na região Norte ${ }^{25}$. Comparando-se as distribuições de cursos e populações, evidenciam-se grandes discrepâncias entre as regiões: enquanto Sul e Sudeste concentravam $80 \%$ dos cursos e $57,31 \%$ da população, Norte e Nordeste, com $35,69 \%$ da população do país, possuíam $14,4 \%$ dos cursos. A desigualdade na distribuição dos cursos é algo preocupante, com reflexos na assistência prestada à população, em virtude tanto da carência de profissionais em algumas localidades, a exemplo da região Norte, quanto de divergências corporativas nas regiões de maior concentração profissional, a exemplo do Sudeste ${ }^{24}$.

A Carta de Vitória (2004), documento-síntese do 1ํㅡㄹ Congresso Nacional do Ensino da fisioterapia, constitui referencial para a qualidade da formação na área. $O$ documento sublinha os principais problemas do ensino da fisioterapia e propõe algumas medidas de referência para a qualidade do ensino: carga de 4.500 horas; adequação dos currículos às necessidades regionais; incorporação de princípios e diretrizes do SUS no processo de formação; e desenvolvimento de práticas comunitárias. Ainda como parte integrante do processo de mudança na formação profissional em fisioterapia, destacam-se as contribuições da Rede Unida (Associação que reúne projetos, instituições e pessoas interessadas na mudança da formação dos profissionais de saúde) na mobilização, aglutinação, discussão, crítica e proposição de novos modelos de formação em saúde no país, em que a formação em fisioterapia tem obtido crescente destaque ${ }^{24}$. 


\section{4 ÉTICA}

Segundo Ferreira (2005), a ética pode ser definida como "O estudo dos juízos de apreciação referentes à conduta humana, do ponto de vista do bem e do mal". Ou ainda, segundo o mesmo autor, a ética compreenderia um "Conjunto de normas e princípios que norteiam a boa conduta do ser humano" 26 . A ética estabelece o que é correto, errado, permitido ou desejado relativamente a uma ação ou decisão. Dessa forma, ela define a forma como os integrantes da sociedade devem agir.

A palavra ética vem do grego ethos que significa "caráter", "modo de ser" que se vai adquirindo durante a vida. $O$ termo moral procede do latim, mores significa "modo de ser", "caráter". Portanto, as duas palavras têm um sentido quase idêntico, porém as diferenças se deram devido a aculturação da ética no mundo romano. Não obstante, no contexto acadêmico, o termo "ética" refere-se à filosofia moral, isto é, ao saber que reflete sobre a dimensão da ação humana, enquanto "moral" denota os diferentes códigos morais concretos. A moral responde à pergunta "O que devemos fazer?" E a ética, "Por que devemos?"27.

A ética ou a filosofia moral tem como objetivo explicar o fenômeno moral, dar conta racionalmente da dimensão moral humana. A ética é indiretamente normativa. A moral é um saber que oferece orientações para ações em casos concretos, enquanto que a ética é normativa em sentido indireto, pois não tem uma incidência direta na vida cotidiana, quer apenas esclarecer reflexivamente o campo da moral ${ }^{27}$.

A ética não se identifica com nenhum código moral, mas isso não significa que ela seja neutra diante dos diferentes códigos, pois ela é crítica dos costumes morais. Sendo assim a ética tem uma tripla função: 1) esclarecer o que é a moral, quais são seus traços específicos; 2) fundamentar a moralidade, ou seja, procurar averiguar quais são as razões que conferem sentido ao esforço dos seres humanos de viver moralmente; 3 ) aplicar aos diferentes âmbitos da vida social os resultados obtidos nas duas primeiras funções, de maneira que se adote uma moral crítica em vez da subserviência a um código 27 .

A reflexão ética traz à luz a discussão sobre a liberdade de escolha. A ética interroga sobre a legitimidade de práticas e valores consagrados pela tradição e pelo costume. Abrange tanto a crítica das relações entre os grupos, dos grupos nas instituições e perante elas, quanto a dimensão das ações pessoais. Trata-se, portanto, 
de discutir o sentido ético da convivência humana nas suas relações com várias dimensões da vida social: o ambiente, a cultura, a sexualidade e a saúde ${ }^{28}$.

Atualmente, a ética passou a fazer parte do discurso da população, dos meios de comunicação, de profissionais de várias áreas, com seu significado nem sempre utilizado de forma correta. Talvez devido ao pouco conhecimento formal que a maioria das pessoas tem da ética, muitas não sabem propriamente o que é a ética, qual a sua finalidade e como ela atua ${ }^{29}$.

Muitas vezes, a palavra ética é utilizada também como adjetivo, com a finalidade de qualificar uma pessoa ou uma instituição como sendo boa, adequada ou correta. O ideal é sempre utilizá-la na forma adverbial, ou seja, ela própria merecendo ser qualificada - eticamente adequada ou eticamente inadequada -, mas não pressupondo que a ética, no seu sentido substantivo, sempre se associe ao bom, ao adequado e ao correto $^{29}$.

A ética propõe-se a compreender os critérios e os valores que orientam 0 julgamento da ação humana em suas múltiplas atividades, principalmente aquelas que dizem respeito ao trabalho e à vida humana associada, isso como disciplina ${ }^{30}$. Dessa forma, ela permite uma reflexão crítica sobre o comportamento humano, reflexão que interpreta, discute e problematiza, investiga os valores, princípios e o comportamento moral ${ }^{31}$.

A tarefa atual da ética é a procura e o estabelecimento das razões que justificam o que "deve ser feito", e não o "que pode ser feito", ou seja, as razões para fazer ou deixar de fazer algo, aprovar ou desaprovar algo, definir o que é bom e o que é mal, o justo e o injusto ${ }^{32}$. Assim, a ética envolve motivação, resultados, ações, ideais e valores, princípios e objetivos e pode ser considerada como uma questão de indagações e não de normatização do que é certo e do que é errado ${ }^{33}$.

\subsection{DEONTOLOGIA}

A deontologia deriva-se do grego déon ou deontos/logos e significa o estudo dos deveres ou obrigação ${ }^{27,32}$. Emerge da necessidade de um grupo profissional de autorregular, ou seja, os membros do grupo devem cumprir as regras estabelecidas num código e fiscalizadas por uma instância superior. O objetivo da deontologia é reger os comportamentos dos membros de uma profissão para alcançar a excelência 
no trabalho, tendo em vista o reconhecimento pelos pares, garantir a confiança do público e proteger a reputação da profissão ${ }^{32}$.

Dessa forma, a ética deontológica caracteriza-se por normas a serem seguidas. Essas normas são provisórias, orientam comportamentos cotidianos e atitudes práticas para atender a determinadas situações e delimitar o caminho das pessoas inseridas em um grupo ${ }^{6}$. A análise das consequências de um ato ou comportamento não deve influir no julgamento moral sobre as ações das pessoas ${ }^{30}$.

Muitas vezes utiliza-se a expressão anglosaxónica professional ethics para designar a deontologia. Mas a ética não se reduz à deontologia. Alguns autores alertam para a necessidade de ir além do mero cumprimento das normas deontológicas. Seguir os princípios éticos vertidos nos códigos deontológicos porque o seu incumprimento tem consequências sociais. As ações são apenas conformes à norma e não conformes ao valor. Se o valor não é assumido pelo agente, este não age racionalmente, de forma livre e responsável, de acordo com aquilo que, interiormente, sabe que deve fazer ${ }^{32}$.

A deontologia trata do estudo do conjunto dos deveres profissionais estabelecidos num código específico que, muitas vezes, propõe sanções para os infratores. Neste sentido, a deontologia é uma disciplina da ética especialmente adaptada ao exercício de uma profissão. Em regra, os códigos de deontologia têm por base grandes declarações universais e esforçam-se por traduzir o sentimento ético expresso nestas, adaptando-o às particularidades de cada profissão e de cada país ${ }^{32}$.

Em resumo, a deontologia determina o dever que regula uma dada situação ${ }^{34}$; o sujeito apenas reflete sobre o melhor meio de agir em conformidade com ele: utilizase o raciocínio "normativo", que identifica e aplica uma norma que corporiza um dado valor; é, por isso, uma forma de hetero-regulação: o bom comportamento decorre da execução de uma norma, de uma obrigação imposta do exterior ${ }^{32}$.

\subsection{BIOÉTICA}

O nascimento da bioética tem suas raízes ideológicas nas ruínas da Segunda Guerra Mundial quando se estimulou a consciência dos homens a uma profunda reflexão devido as atrocidades cometidas em nome da ciência, com o intuito de se estabelecer uma fronteira entre a ética e o comportamento. A partir desse marco, a exigência de uma ética no campo biomédico fundamentada na razão e nos valores 
objetivos da vida e da pessoa estimulou a consciência crítica para uma profunda reflexão com o intuito de estabelecer a fronteira entre a ética e o comportamento ${ }^{35}$.

A Encyclopedia of bioethics, editada por Reich em 1978, define a bioética como o estudo sistemático das dimensões morais, incluindo visão, decisões e normas morais que envolvam as ciências da vida e o cuidado com a saúde, com a utilização de uma variedade de metodologias éticas num contexto multidisciplinar, marcado por temas direta ou indiretamente ligados à qualidade de vida no seu sentido mais amplo ${ }^{31}$.

A palavra "bioética", ética da vida, é uma reflexão necessariamente multiprofissional, relacionada aos diversos campos que atuam na saúde, na vida, nela participando ativamente filósofos, teólogos, sociólogos, antropólogos, juristas, religiosos, médicos, biólogos, políticos, economistas, dentre outros. Sua perspectiva é autônoma e humanista, tende a ver a pessoa humana em sua globalidade ${ }^{36,37}$.

Dessa forma, o senso de humanidade é inerente e fundamental à bioética. Pensar bioética é pensar de forma solidária, é assumir uma postura íntegra frente ao outro e, consequentemente, frente à sociedade e à natureza. Com base nestas colocações é possível afirmar que a bioética é uma reflexão compartilhada, complexa e interdisciplinar sobre a adequação das ações que envolvem a vida e o viver ${ }^{29}$.

Os temas abordados dentro da bioética são variados: vão desde os dilemas éticos enfrentados pelo profissional de saúde, até problemas gerados pelas tecnologias de ponta que em poucos anos de existência, ampliou substancialmente seu campo de estudo, ação e influência. Dessa forma, a discussão da bioética surge para contribuir na procura por respostas equilibradas frente aos conflitos atuais e aos das próximas décadas ${ }^{35}$.

De acordo com esse contexto e objetivando melhor sistematização e compreensão de sua área de estudo e abrangência, a bioética pode ser classificada em dois grandes campos de atuação, de acordo com sua historicidade: a bioética das situações emergentes que trata das situações que emergiram historicamente nas últimas décadas, como produto do desenvolvimento científico e tecnológico, como projeto genoma; e a bioética de situações persistentes que trata das situações historicamente persistentes no processo evolutivo da humanidade e que continuam se repetindo, apesar do atual estágio de desenvolvimento do mundo como a exclusão social, as discriminações de gênero, raça, sexualidade e outras, temas da equidade, 
da universalidade e da alocação, distribuição e controle de recursos econômicos, dentre outros ${ }^{35}$.

Observa-se diante disso, que a bioética, em seu início, defrontou-se com dilemas éticos criados pelo desenvolvimento da medicina. As pesquisas em seres humanos, uso humano da tecnologia, perguntas sobre a morte e o morrer são algumas áreas sensíveis dos anos 1990. As questões originais da bioética se expandiram para problemas relacionados com os valores nas diversas profissões. Grande número de temas sociais foi introduzido na abrangência da temática da bioética, tais como a saúde pública, alocação dos recursos em saúde, saúde da mulher, questão populacional e ecologia 38 .

Diante do exposto, o termo bioética designa um conjunto de práticas pluridisciplinares e pesquisas que objetivam conter os conflitos e as contestações morais aplicadas principalmente pelo avanço das ciências biomédicas ${ }^{39}$. De acordo com o objetivo deste estudo, a bioética, apesar de apresentar suas vertentes, será abordada quanto a sua relação e importância na formação e na prática profissional, pois os princípios que a norteiam são fundamentais para estimular uma reflexão sobre o tema.

A bioética como disciplina, estimula o desenvolvimento moral e ético na formação pessoal e profissional do indivíduo. Auxilia também na preparação dos futuros profissionais ou até mesmo graduados a enfrentar as diversas situações com as quais vão se deparar ao longo da experiência profissional ${ }^{40}$. Esses conflitos bioéticos ficam mais claros quando discutidos dentro de uma perspectiva interdisciplinar. Muitas das ferramentas apresentadas - convergência, divergência, realimentação positiva e negativa, homeostase, homeorrese, processos de tomada de decisão - podem facilitar a compreensão e auxiliar na busca de possíveis soluções ${ }^{29}$.

Observa-se a preocupação em buscar soluções para os dilemas éticos baseados em uma perspectiva aceitável para as pessoas envolvidas, por meio de dois princípios de caráter deontológico: do grego deon, obrigação, dever (não maleficência e justiça) e dois de caráter teleológico: do grego telos, fim, finalidade (beneficência e

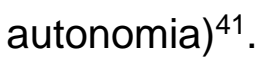

Diante dessa visão, cria-se o Relatório de Belmont nos Estados Unidos em 1979, destacando os princípios fundamentais da bioética: não maleficência, beneficência, respeito à autonomia e justiça - que, a partir de então, tornar-se-ia fundamental para o desenvolvimento da bioética e ditaria uma forma peculiar de definir 
e manejar os valores envolvidos nas relações dos profissionais de saúde e seus pacientes.

Esses princípios foram descritos e discutidos no livro "Principles of Biomedical Ethics" dos norte-americanos Tom L. Beauchamp e James F. Childress ${ }^{31,42}$. Estes não possuem caráter absoluto, nem têm prioridade um sobre o outro, servem como regras gerais para orientar a tomada de decisão frente aos problemas éticos e para ordenar os argumentos nas discussões de $\operatorname{casos}^{43}$. A Não maleficência, Beneficência, Respeito a Autonomia e Justiça são obrigações que devem ser cumpridas, a não ser que entrem em conflito com outro dever igual ou mais forte. Segue abaixo o quadro sobre os princípios e seus conceitos (Quadro 1) de acordo com Beauchamp \& Childress $(1994)^{43}$ e Santos, Leon \& Funghetto $(2011)^{44}$. 
Quadro 1 - Princípios da bioética e seus conceitos.

\begin{tabular}{|c|c|}
\hline Princípio & Conceito \\
\hline Não maleficência & $\begin{array}{l}\text { O profissional de saúde tem o dever de, intencionalmente, não } \\
\text { causar mal e ou danos a seu paciente. }\end{array}$ \\
\hline Beneficência & $\begin{array}{l}\text { Significa fazer o bem. O profissional de saúde tem a obrigação } \\
\text { moral de agir para o benefício do outro. Significa fazer o que é } \\
\text { melhor para o paciente, não só do ponto de vista técnico- } \\
\text { assistencial, mas também do ponto de vista ético. É usar todos } \\
\text { os conhecimentos e habilidades profissionais a serviço do } \\
\text { paciente, considerando, na tomada de decisão, a minimização } \\
\text { dos riscos e a maximização dos benefícios do procedimento a } \\
\text { realizar. }\end{array}$ \\
\hline Autonomia & $\begin{array}{l}\text { É a capacidade de uma pessoa para decidir fazer ou buscar } \\
\text { aquilo que ela julga ser o melhor para si mesma. Já o respeito à } \\
\text { autonomia significa ter consciência deste direito da pessoa de } \\
\text { possuir um projeto de vida próprio, de ter seus pontos de vista } \\
\text { e opiniões, de fazer escolhas autônomas, de agir segundo seus } \\
\text { valores e convicções. Este princípio está eticamente } \\
\text { fundamentado na dignidade da pessoa humana. }\end{array}$ \\
\hline Justiça & $\begin{array}{l}\text { Justiça está associada preferencialmente com as relações entre } \\
\text { grupos sociais, preocupando-se com a equidade na distribuição } \\
\text { de bens e recursos considerados comuns, numa tentativa de } \\
\text { igualar as oportunidades de acesso a estes bens. }\end{array}$ \\
\hline
\end{tabular}

Beauchamp TL, Childress JF. Principles of Biomedical Ethics. $4^{\mathrm{a}}$ Ed. New York: Oxford University Press, 1994; Santos LR, Leon CGRMP, Funghetto SS. Princípios éticos como norteadores no cuidado domiciliar. Cien Saude Colet. 2011; 16(Supl. 1):855-863.

Acredita-se que, no contexto da assistência à saúde, é essencial considerar os princípios de beneficência e não-maleficência em conjunto, na medida em que nem sempre o que é considerado um benefício do ponto de vista do profissional da área da saúde, também o é do ponto de vista do paciente. Esta atitude é conhecida como "atitude paternalista" que consiste em negligenciar a "vontade" do paciente, representada pelo aforisma de que é o profissional que sabe o que é melhor para o 
seu paciente ${ }^{43}$. E o princípio da beneficência regula as instâncias éticas das profissões da saúde e estrutura a deontologia profissional ${ }^{6}$.

Então, pode-se redefinir que, bioética se refere a um estudo sistemático da conduta humana examinada à luz dos valores e dos princípios morais. Trata-se de um "braço" da ética geral. Sua tarefa não é elaborar novos princípios éticos gerais, mas aplicar esses princípios ao âmbito das ciências da vida e do cuidado da saúde, em especial aos novos problemas que estão surgindo.

\subsection{DIRETRIZES CURRICULARES E A INTRODUÇÃO DA BIOÉTICA NAS MATRIZES CURRICULARES DO CURSO DE FISIOTERAPIA}

O Conselho Nacional de Educação instituiu, em 19 de fevereiro de 2002, as Diretrizes Curriculares Nacionais do Curso de Graduação em fisioterapia por meio da resolução CNE/CES nำ 45 . Foi um marco importante na orientação e transformação do ensino em que são definidos princípios, fundamentos e condições para a formação em todas as instituições nacionais de ensino. O perfil do profissional egresso passou a ser generalista com formação crítica, humanista e reflexiva, e com capacitação para atuar em todos os níveis de atenção ${ }^{4}$.

Embora o Conselho Nacional de Educação (CNE) propor, através das diretrizes curriculares, maior flexibilidade na organização de cursos com ampla liberdade na composição da carga horária e unidades de estudos a serem ministradas e redução da duração dos cursos, as mesmas foram muito criticadas por não estabelecer essa a carga horária mínima e por permitir a excessiva flexibilização na formação universitária ${ }^{6,47}$. Por outro lado, as diretrizes configuram instrumento imprescindível para a garantia da qualidade do ensino, pois estabelecem padrões mínimos nacionais e direcionam a formação de acordo com realidade epidemiológica e com os novos modelos de atenção à saúde ${ }^{24}$.

Os cursos de fisioterapia, conforme instituído nas diretrizes curriculares nacionais, deveriam estruturar-se a partir dos princípios do SUS e adequar a formação dos profissionais ao perfil epidemiológico da população. Mas o objeto de trabalho da profissão continuaria sendo o movimento humano. A responsabilidade profissional, no entanto, não se restringiria ao nível terciário da reabilitação, mas deveria ampliar-se para os níveis primário e secundário. A formação, portanto, deveria aproximar-se do paradigma da promoção da saúde e do campo da saúde coletiva, alargando as 
possibilidades de atuação, direcionadas, prioritariamente, para os determinantes e condicionantes do processo saúde/doença ${ }^{24}$.

Entre as recomendações, as Diretrizes dão ênfase à formação ética dos fisioterapeutas no que se refere aos princípios necessários à sua formação e atuação. As questões éticas perpassam o exercício profissional, com concepções advindas da formação moral, da deontologia, acrescidas de reflexões conceituais e de desafios provenientes da experiência profissional. Esses conhecimentos não fazem parte de um saber formal e requerem avaliação e acompanhamento constantes para o desenvolvimento ético dos fisioterapeutas ${ }^{8}$.

E foi a partir de 2001, com as Diretrizes Curriculares Nacionais dos Cursos de Graduação da Saúde que a disciplina bioética apareceu como um dos conhecimentos a serem adquiridos durante a graduação ${ }^{48}$. Dentre os diversos aspectos que sinalizavam para a mudança da trajetória curricular do curso de fisioterapia, indicados pela Comissão de Especialistas (responsável pela realização das Diretrizes), destacavam-se os aspectos ligados ao perfil que o formando deveria ter e os conhecimentos necessários para o desenvolvimento de certas competências e habilidades gerais essenciais para atuar na área da saúde ${ }^{8,49}$.

Este fato comprova-se nas Diretrizes Curriculares que diz que o curso de fisioterapia tem como perfil do formando egresso/profissional o fisioterapeuta, com formação generalista, humanista, crítica e reflexiva, capacitado a atuar em todos os níveis de atuação em saúde. E que o mesmo detém visão ampla e global, respeitando os princípios éticos/bioéticos, e culturais do indivíduo e da coletividade ${ }^{46}$.

Como o próprio texto das diretrizes sinaliza os profissionais devem realizar seus serviços dentro dos mais altos padrões de qualidade e dos princípios da ética/bioética, tendo em conta que a responsabilidade da atenção à saúde não se encerra com o ato técnico, mas sim, com a resolução do problema de saúde, tanto em nível individual como coletivo (Art.4ํㅜ - inciso I) ${ }^{46}$.

Dessa forma, a implantação das Diretrizes Curriculares Nacionais (DCN) das profissões da saúde que indicaram a necessidade de inclusão da bioética nas matrizes curriculares e difusão dos princípios bioéticos por meio da implantação do Sistema Brasileiro de Revisão Ética das Pesquisas (Sistema CEP/CONEP) ${ }^{50}$.

Outro fato que configura a presença da bioética na formação do fisioterapeuta é que as Diretrizes Curriculares deixam exposto que o profissional deve ter como competências e habilidades a tomada de decisões, ou seja, o seu trabalho deve estar 
fundamentado na capacidade de tomar decisões visando o uso apropriado, eficácia e custo-efetividade, da força de trabalho, de medicamentos, de equipamentos, de procedimentos e de práticas. Para este fim, os mesmos devem possuir competências e habilidades para avaliar, sistematizar e decidir as condutas mais adequadas, baseadas em evidências científicas (Art.4 $4^{\circ}$ - inciso II) ${ }^{46}$.

O Fisioterapeuta, como profissional pleno da área de saúde, não abre mão de seus direitos e responsabilidades profissionais, devendo ampliar suas áreas de atuação no campo da saúde funcional através da constante capacitação ética, técnicocientífica e política, contribuindo decisivamente para a melhoria das condições de vida e saúde da população brasileira. No aspecto referente à autonomia técnica profissional, o fisioterapeuta vem buscando há anos seu aprimoramento científico por meio de uma nova concepção que inclui a consulta diagnóstica própria, com a competência para solicitar exames complementares e executar exames e testes específicos, realizar encaminhamentos criteriosos a outros profissionais de saúde, quando necessários, e prescrever, ministrar, reavaliar e dar alta nos serviços de fisioterapia ${ }^{14}$.

Porém, um grande conflito que se enfrenta na prática profissional advém da influência mecanicista e diz respeito a trabalhar com o toque sobre o corpo do outro de forma próxima e incisiva. Seria possível tocar uma pessoa, de forma terapêutica, sem se estabelecer alguma noção de vínculo? Acredita-se que os profissionais da fisioterapia são graduados para lidarem não apenas com as doenças, mas também com suas sequelas, sejam elas de ordem física, psíquica ou social ${ }^{51}$. E qual seria a disciplina base na formação do fisioterapeuta para trabalhar com o discente sobre tal tema de forma reflexiva e voltada para a prática profissional?

\subsection{AS DISCIPLINA DE ÉTICA E OU DEONTOLOGIA E BIOÉTICA NA FORMAÇÃO DO FISIOTERAPEUTA}

No ensino da graduação em fisioterapia a ética faz parte da matriz curricular como disciplina. $\mathrm{O}$ conteúdo programático deve ter um espaço para que o aluno estimule a reflexão sobre o saber ético, fazendo com que ele raciocine

adequadamente para conduzir com comprometimento, conhecimento, atitude e responsabilidade a sua profissão. Entretanto, o saber em ética deve agregar e integrar grande parte das disciplinas do currículo de fisioterapia, principalmente o estágio 
supervisionado, para que todos tenham uma linguagem comum, relacionada aos princípios éticos que norteiam a profissão.

A bioética é uma disciplina jovem no Brasil e os primeiros passos para seu fortalecimento acadêmico foram dados, ainda no início dos anos 1990, com a criação dos Comitês de Ética em Pesquisa que tiveram um papel importante na institucionalização da disciplina bioética ${ }^{8,52}$. A mesma pode auxiliar no enfrentamento de situações de difícil mediação moral como o fim da vida, a morte, a negligência, tomada de decisões, dentre outras. O campo de influência da bioética perpassa praticamente todas as áreas acadêmicas, inserindo-se no contexto internacional como referencial teórico que instiga à análise e discussão de dilemas morais de amplo espectro ${ }^{40}$.

O vínculo entre ética e bioética e a profissão fisioterapia também é uma realidade recente e em caminho de consolidação. Esse conhecimento incorpora saberes multidisciplinares e interdisciplinares considerados essenciais para todas as carreiras da área da saúde. Inclui contínuo e crescente processo de evolução de suas concepções, fundamentadas em conhecimentos da antiguidade adaptados aos contextos atuais ${ }^{7,8}$.

A disciplina ética e deontologia hoje é obrigatória nos cursos de fisioterapia e está inserida no currículo mínimo proposto pelo MEC, mas a abordagem desse conteúdo difere entre as instituições. É provável que o enfoque didático dado ao Código tenha pontos falhos, que precisam ser identificados. Sugere-se que ministrar uma disciplina que discute os dilemas éticos da profissão e a bioética e possa permitir aos alunos estabelecer melhor relação entre os problemas enfrentados e o que é estabelecido pelo Código ${ }^{52}$.

\subsection{A IMPORTÂNCIA DA BIOÉTICA NA FORMAÇÃO DO FISIOTERAPEUTA}

Para a fisioterapia, reabilitar implica restaurar movimentos ou funções comprometidas, capacitar mediante evolução das potencialidades para consequente interação social e autonomia ${ }^{53}$. A formação e a prática da fisioterapia, atualmente, estão direcionadas para uma atuação generalista, ou seja, o fisioterapeuta forma-se capaz de atuar em todas as áreas que lhe são de direito. Porém, há uma tendência no ensino superior de fisioterapia em valorizar o individual, a terapêutica, a especialidade e a utilização de métodos e técnicas sofisticadas ${ }^{46,54}$. 
Nos tempos de hoje a fisioterapia ainda é fortemente influenciada pela visão cartesiana de homem que é caracterizada pela separação entre corpo e alma e pelo modelo biologicista que combate os sintomas e as causas das doenças, sem se preocupar com outros determinantes, como o emocional, psicológico e social que interferem no estado de saúde e doença das pessoas ${ }^{55}$.

Para que o fisioterapeuta preserve essa autonomia profissional, é fundamental que ele atenda as expectativas da sociedade e as demandas de competência profissional, bem como a competência ética ${ }^{56}$. É importante ressaltar que hoje no Código de Ética da Fisioterapia e Terapia Ocupacional a autonomia agrega conteúdos bioéticos, dessa forma a autonomia profissional torna-se mais prevalente que a do cliente, caracterizando o fisioterapeuta como o lado mais forte da relação terapeutapaciente ${ }^{57}$. Pode-se considerar que essa evolução quanto a preocupação com a autonomia profissional é um marco profissional, porém trará também mais dilemas e responsabilidades éticas mais complexas.

O conhecimento sobre ética e bioética representa requisito fundamental para o desenvolvimento profissional, especialmente nesse momento de consolidação profissional e avanço científico e tecnológico acelerado. No entanto, a forma como o vínculo sobre estes temas e a fisioterapia vem sendo tratado na produção científica brasileira e internacional é objeto de consideração, pois o processo de tomada de decisão parece ainda ser restrito à relação entre o terapeuta e seu paciente ${ }^{58}$.

O desenvolvimento da fisioterapia, aliado às mudanças na educação e na saúde, faz com que a autonomia e os dilemas éticos do fisioterapeuta sejam maiores a cada dia, expandindo seu papel no cuidado do paciente. Para além do Código de Ética, as noções de bioética são centrais no preparo de graduandos para os desafios profissionais. A capacidade de tomar decisões éticas de alunos no último ano de fisioterapia de universidade que oferece bioética tem resultados significantemente melhores nos quesitos referentes à relação com outros profissionais da saúde ${ }^{52}$.

Como boa parte dos alunos optam pela conduta bioética, pode-se ponderar que o Código não parece ser suficiente para guiar os fisioterapeutas na complexidade dos dilemas sugeridos, mas que os graduandos incorporam valores fundamentais ao relacionamento com os colegas de profissão e de outras áreas da saúde. Acredita-se que a disciplina bioética funcione como um aprimoramento para enfrentar dilemas éticos mais complexos, que o Código de Ética não aborda. Entretanto, vale lembrar que, além dos valores adquiridos ao longo do curso, os alunos guardam suas 
características individuais no que se refere a princípios éticos, valores humanos, caráter moral e índole 52 .

Sugere-se que essa disciplina ofereça melhores condições para desenvolver os valores e virtudes requeridas na profissão, além de estabelecer bases mais adequadas para o relacionamento interprofissional, fator importante para a elevação do status da fisioterapia. No entanto ainda persiste a carência de conhecimento do Código de Ética, bem como dificuldade para a tomada de decisões frente aos dilemas éticos da prática clínica ${ }^{52}$.

Em termos pedagógicos, como disciplina, o ensino da bioética abre caminhos para discussões críticas e análises que ajudam a discernir o que é bom e correto com base nos valores morais vigentes. Segundo Heck (2005), "são os princípios bioéticos que estabelecem padrões que orientam, guiam e avaliam condutas" 59,60 .

Dessa forma, a principal indagação que se coloca aqui é: como os fisioterapeutas têm sido preparados, para o pleno exercício da sua função? Será que há, na trajetória de formação, espaço garantido para as abordagens bioéticas? Ao atentar para a necessidade de garantir aos fisioterapeutas o acesso aos fundamentos éticos, é cabível investigar se a Bioética tem sido incluída no currículo dos cursos de fisioterapia. 


\section{MATERIAIS E MÉTODOS}

Esta pesquisa caracteriza-se por ser um estudo descritivo desenvolvido por meio de abordagem mista (utilizando-se o método quantitativo e qualitativo) associada à revisão sistematizada da literatura. Foi efetuada, ainda, uma análise reflexiva sobre o perfil das disciplinas de ética (associada ou não a deontologia) e bioética ministradas nos cursos de fisioterapia das Universidades e Centros Universitários, públicos e privados, no Brasil.

O período da realização do estudo ocorreu de maio de 2013 a janeiro de 2015 e foi dividida em quatro etapas (Figura 01):

- Etapa I: Realização de uma revisão sistemática sobre o tema da bioética no contexto da formação acadêmica de profissionais da área da saúde.

- Etapa II: Realização de uma revisão sistemática sobre a disciplina de bioética no contexto da formação acadêmica do fisioterapeuta.

- Etapa III: Pesquisa através da identificação das Universidades e Centros Universitários que ofertam o curso de fisioterapia no Brasil (APÊNDICE).

- Etapa IV: Análise das matrizes curriculares e ou Projeto Pedagógico do curso de fisioterapia para identificar a presença das disciplinas de ética e ou deontologia e bioética (APÊNDICE).

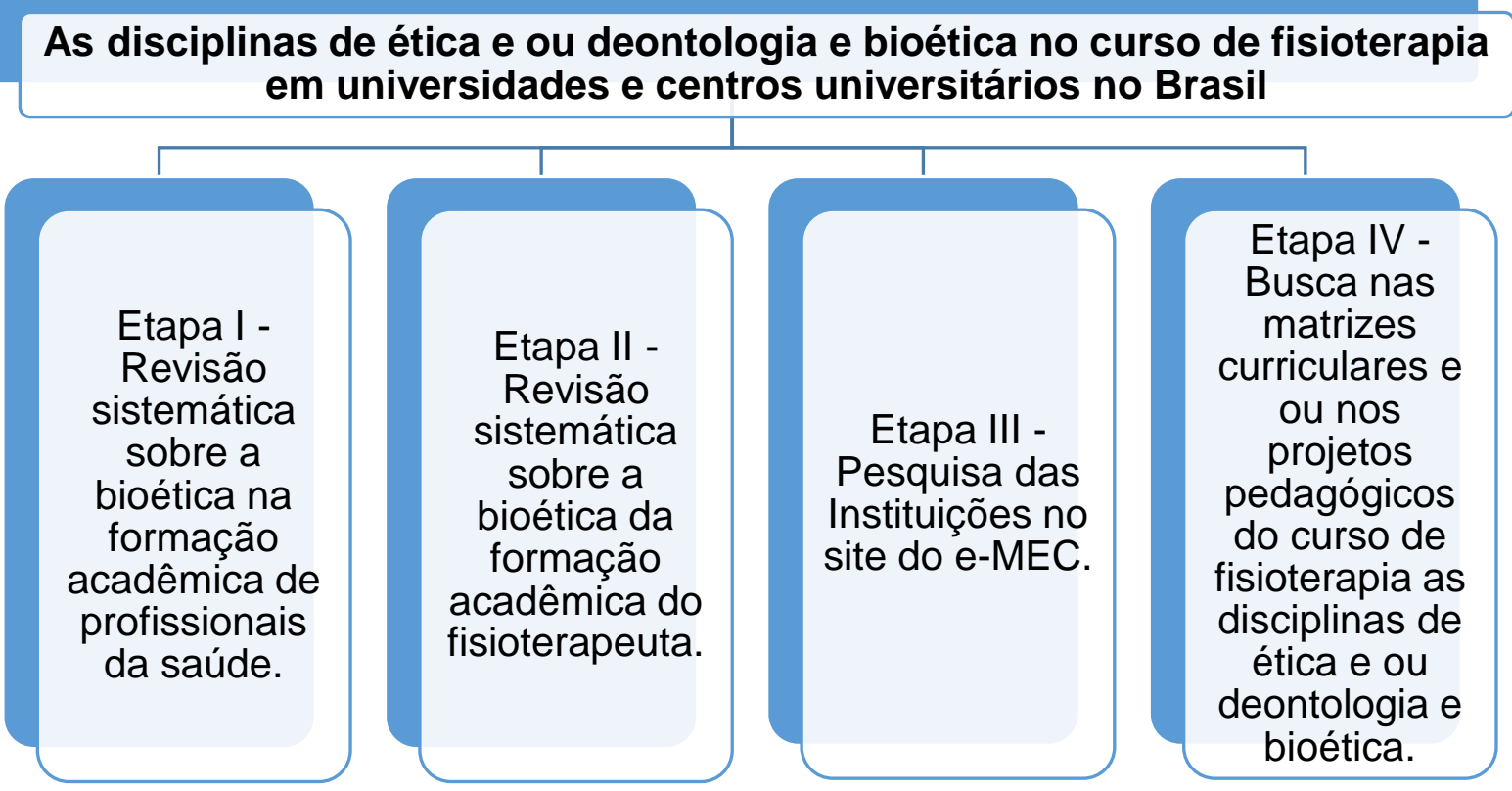

Figura 01 - Fluxograma dos Métodos do Estudo 
4.1. Etapa I: Revisão sistemática sobre a bioética na formação do profissional de saúde.

A etapa I deste estudo consistiu em realizar uma revisão sistematizada através da busca de artigos nas bases de dados para identificar como os mesmos abordam a bioética na formação acadêmica do profissional de saúde de forma geral e a importância que os autores dão à disciplina.

4.2. Etapa II: Revisão sistemática sobre a disciplina de bioética na formação profissional do fisioterapeuta.

Esta etapa consistiu em analisar o que os estudos dizem sobre a importância da disciplina de bioética na formação acadêmica do fisioterapeuta. Foi também realizada uma revisão sistematizada, através de uma pesquisa nas bases de dados nacionais e internacionais, para melhor aprofundamento do tema e análise dos resultados.

\subsection{Etapa III: Instituições: pesquisa eletrônica.}

A terceira etapa consistiu na coleta, durante o mês janeiro de 2015, de informações sobre as instituições de ensino superior no Brasil que oferecem o curso de fisioterapia, tendo como referência a lista de cursos cadastrados disponibilizada pelo Ministério de Educação e Cultura (MEC) em seu endereço eletrônico na rede nacional de computadores (http://emec.mec.gov.br/) (Figura 02).

A partir da relação dessas Instituições, foram selecionadas somente as Universidades e Centros Universitários, pois somente estes possuem autonomia para criarem seus cursos. Todos os outros tipos de instituição precisam de uma autorização do poder público. Essas instituições compuseram a amostra do estudo que foi de 234 instituições, sendo 145 universidades e 89 centros universitários. 
Etapa III

Pesquisa das instiuições que possurem o curso de fisioterapia no Brasil pelo site do E-mec.

Seleção das universidades e centros universitários que possurem o curso de fisioterapia.

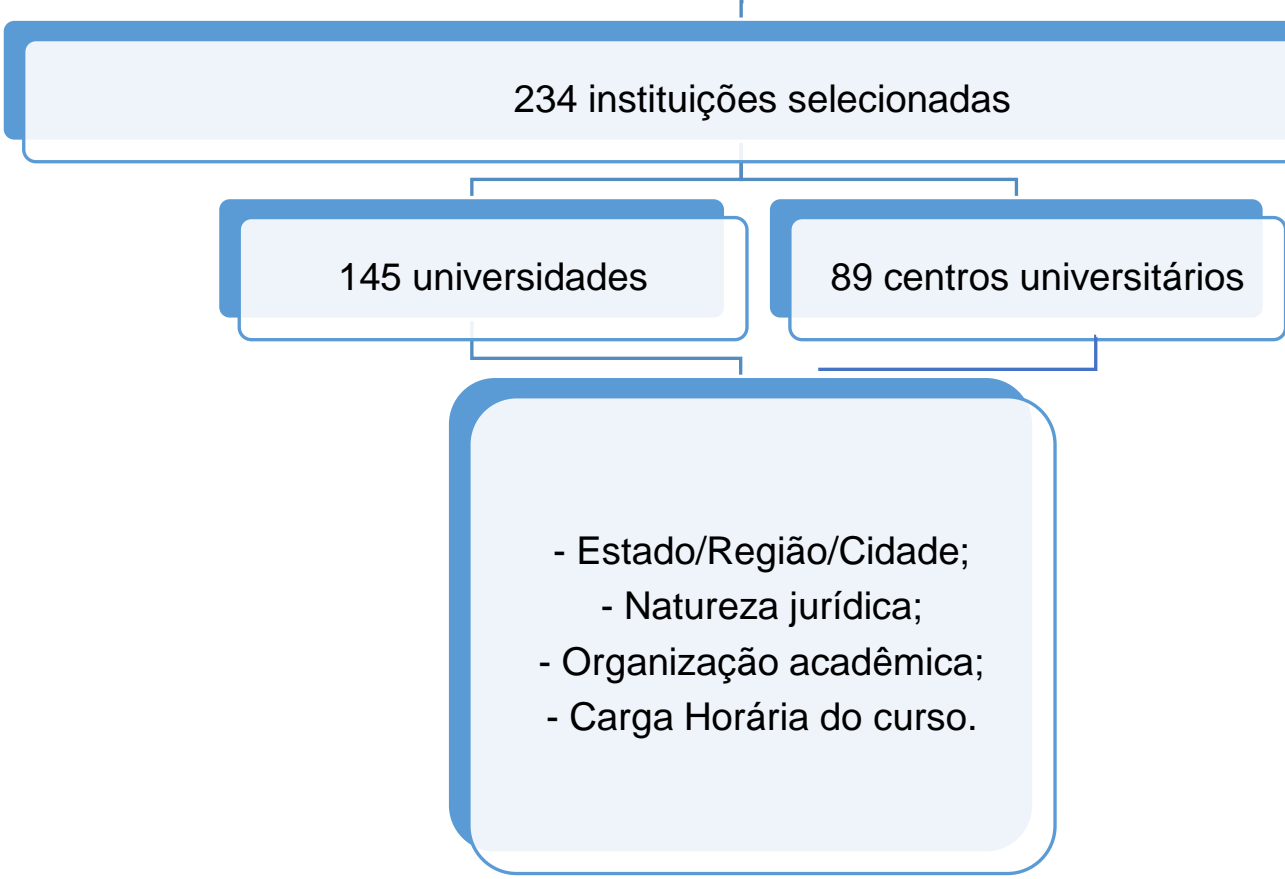

Figura 02 - Fluxograma da Etapa I

No site do E-mec também foi possível identificar seus endereços eletrônicos o estado a qual pertenciam, a quantidade de Instituições por estado/região, a natureza jurídica - pública ou privada - e a organização acadêmica de cada uma - universidade ou centro universitário (Figura 02) (APÊNDICE).

Após a coleta destes dados, os endereços eletrônicos das universidades e centros universitários foram acessados para identificar a cidade que a Instituição de Ensino pertencia, a carga horária total do curso de fisioterapia e o número de semestres. A Instituição que apresentava o formato do curso anual, o mesmo foi convertido em semestres para permitir uma melhor análise dos dados (Figura 02) (APÊNDICE).

Para as instituições que não apresentavam a carga horária total do curso de fisioterapia, porém apresentavam a matriz curricular e a carga horária de todas as 
disciplinas e estágios, foi realizada a soma das mesmas para assim chegar ao valor aproximado e possibilitar a inclusão da instituição (Figura 02) (APÊNDICE).

4.4. Etapa IV: Análise das matrizes curriculares e ou Projeto Pedagógico do curso de Fisioterapia

Neste momento buscou-se encontrar as matrizes curriculares do curso de fisioterapia e analisar se foram incluídas as disciplinas de ética e ou deontologia e bioética. Em caso positivo, em qual momento (semestre) do curso a mesma foi ministrada e com que carga horária. Caso a instituição apresentasse o formato da disciplina em caráter anual, o mesmo foi convertido em semestre no processo de análise dos dados (APÊNDICE).

Para as Instituições que apresentavam mais de uma matriz curricular, optou-se por analisar a mais atualizada.

As universidades e centros universitários que apresentavam em domínio público o Projeto Pedagógico do Curso, o mesmo também foi coletado com o objetivo de encontrar e analisar as ementas das disciplinas, o conteúdo programático e o referencial bibliográfico.

Durante esta etapa também foi observado se as disciplinas de ética e ou deontologia e bioética eram ministradas isoladamente ou associadas a outros conteúdos, como por exemplo, Filosofia, Introdução a Fisioterapia, Sociologia, Antropologia, dentre outros. Em caso positivo, também se buscou o período ministrado assim como carga horária, ementa, programa de ensino e referências bibliográficas.

Caso a matriz curricular não apresentasse as disciplinas de ética e ou deontologia e bioética, foi identificado, se possível através das ementas disponíveis ou do Projeto Pedagógico do Curso, a oferta de outras disciplinas que contemplavam o conteúdo de ética e ou Deontologia e bioética, assim como o semestre, carga horária, ementa e referências bibliográficas.

Após a identificação dos ementários da bioética, a abordagem desta disciplina foi classificada de acordo com o estabelecido por Costa e Diniz (2001) que categorizaram as possíveis abordagens em: historicista, filosófica e a temática ${ }^{61}$. Segundo os mesmos autores e Diniz e Guilhem (2002) a historicista remete o nascimento da bioética aos fatos e eventos passados que contribuíram para o seu 
surgimento. A filosófica exige certo domínio da história da filosofia, sendo considerada uma corrente teórica para subsidiar a reflexão sobre os conflitos éticos. E a abordagem temática permite a compreensão do fazer bioético a partir de casos e ou situações da vida que, nos últimos tempos, foram considerados típicos de dilemas da bioética. Dentre os exemplos mais citados estão as situações que envolvem: aborto, alocação de recursos, clonagem, engenharia genética, eutanásia, justiça social, projeto genoma humano e transplante e doação de órgãos. Em geral, essa abordagem refere-se a situações concretas de vida como recurso argumentativo de suporte às suas ideias morais e éticas ${ }^{62}$.

É válido ressaltar que pode haver a integração entre duas ou mais abordagens em uma mesma ementa, dessa forma, a classificação do ementário em uma categoria não exclui a possibilidade de os temas da disciplina de bioética serem trabalhados contemplando as outras duas abordagens supracitadas.

Durante a busca dos dados procurou-se também se havia disponível em domínio público a formação acadêmica do professor que ministrava a disciplina encontrada. Caso houvesse o nome do professor, foi realizada uma busca no diretório do CNPq (http://lattes.cnpq.br) para analisar se no currículo lattes havia alguma trajetória acadêmica do docente relacionadas com a ética, deontologia e bioética.

\subsection{Critérios de Inclusão}

Neste estudo foram incluídas todas as universidades e centros universitários, públicos e privados, que apresentavam os dados disponíveis em seus sites, existentes no Brasil que ofertavam o curso de fisioterapia.

As universidades são instituições de ensino superior que devem oferecer, obrigatoriamente, atividades de ensino, de pesquisa e de extensão em várias áreas do saber. Além do que, elas também têm autonomia e podem criar seus cursos sem permitir permissão ao MEC.

Os requisitos mínimos para ser uma universidade são: um terço do corpo docente deve ter título de mestrado ou doutorado; um terço dos professores devem ter contrato em regime de tempo integral; e desenvolver, pelo menos, quatro programas de pós-graduação stricto sensu (mestrado e doutorado). 
Os centros universitários, assim como as universidades, têm graduações em vários campos do saber e autonomia para criar os cursos de ensino superior. Em geral, são menores e têm menor exigência de programas de pós-graduação.

Também existem algumas regras que os centros universitários precisam cumprir como ter, no mínimo, um terço do corpo docente com mestrado ou doutorado e ter, pelo menos, um quinto dos professores contratados em regime de tempo integral.

\subsection{Critérios de Exclusão}

Foram excluídos deste estudo as faculdades e institutos federais listados pelo site do Ministério da Educação e Cultura (e-MEC), as universidades e centros universitários que, apesar de estarem no site, não ofertavam o curso de fisioterapia, as universidades e centros universitários cujo endereço eletrônico estava indisponível e as instituições para as quais não foi possível obter os dados completos como a matriz curricular, o número de semestres e a carga horária do curso e da disciplina.

As instituições que se encontravam repetidas, ou seja, possuíam várias unidades em diferentes regiões do país, porém com a mesma matriz curricular, também foram excluídas e contabilizadas apenas uma vez.

\subsection{Análise dos dados}

Foi efetuada a análise descritiva dos dados, utilizando-se o Software estatístico Epi-info, versão 7.0. As variáveis quantitativas foram apresentadas em seus valores máximo e mínimo, média, mediana e desvio padrão e as variáveis qualitativas foram expressas através da frequência absoluta e relativa.

Este estudo também utilizou a técnica de análise de conteúdo, em sua vertente qualitativa, para averiguar as ementas e ou programas das disciplinas encontrados. Para a realização desta análise foi utilizado como referência o livro Análise de Conteúdo de Laurence Bardin (2009). Fez-se o levantamento dos dados, a categorização analítica e a transformação dos dados em tabelas para uma melhor visualização ${ }^{63}$. 
5 RESULTADOS 
Artigo 1 - O Ensino da Bioética na Graduação do Profissional de Saúde Paiva LM, Guilhem D, Sousa ALL. O Ensino da Bioética na Graduação do Profissional de Saúde. Medicina (Riberão Preto) 2014;47(4):357-69.

Este artigo está em acordo com o objetivo específico desta tese em realizar revisão sistematizada sobre o tema da bioética no contexto da formação acadêmica de profissionais da área da saúde. 


\title{
O Ensino da bioética na graduação do profissional de saúde
}

\author{
Teaching bioethics in undergraduate of health professionals \\ Letícia M. Paiva', Dirce Guilhem², Ana Luiza L. Sousa ${ }^{3}$
}

\begin{abstract}
RESUMO
Modelo do estudo: Revisāo sistemática da literatura. Objetivo: Conhecer a produçāo científica que explora sobre o ensino da Bioética no processo ensino-aprendizagem dos profissionais de saúde. Metodologia: Estudo exploratório que identificou artigos sobre o ensino da Bioética na graduaçāo do profissional de saúde, publicados no período de 2005 a julho de 2013, publicados nas línguas português, inglês e espanhol. Resultados: Foram selecionados 38 artigos, com o maior número de publicaçōes en 2009 , na área de medicina, com predom ínio de artigo original/em pírico $(50 \%)$. A maioria dos artigos encontrados abrangeu o ensino da Bioética na graduaçāo ( $n=14 ; 36,84 \%)$. Conclusāo: De acordo com os resultados obtidos na presente pesquisa, há uma unanimidade entre os autores quanto a im portância da introduçāo da disciplina de Bioética nas matrizes curriculares dos cursos de graduaçāo en saúde.
\end{abstract}

Palavras-chave: Bioética. Currículo. Ensino. Instituiçōes Acadêmicas. Tomada De Decisōes.

\section{Introdução}

O estudo dos aspectos éticos que envolvem o exercício das profissões de saúde tem merecido crescente atenção nas últimas décadas, em todo o mundo ${ }^{1}$ Diante dos inúmeros acontecimentos e fatos que atentam contra a vida e a dignidade humana, fica cada vez mais evidente que o ensino das disciplinas de ética e bioética de forma isolada e sem comunicação entre si não é suficiente para que os acadêmicos e os profissionais consigam solucionar os dilemas que acometem a todos os seres humanos ${ }^{2}$.

A bioética é uma disciplina jovem no Brasil e os primeiros passos para seu fortalecimento acadê- mico foram dados, ainda no início dos an os 1990, com a criação dos Comitês de Ética em Pesquisa que tiveram um papel importante na institucionalização da disciplina Bioética. ${ }^{3,4} \mathrm{E}$ foi a partir de 2001 , com as Diretrizes Curriculares Nacionais dos Cursos de Građuação da Saúde que a disciplina Bioética apareceu como um dos conhecimentos a serem adquiridos durante a građuação. ${ }^{5}$

Mas a introđução da Bioética nas matrizes curriculares ainda tem sido lenta. $\mathrm{O}$ ensino dessa disciplina é uma tarefa que exige mobilidade e criatividade e também a modificação dos moldes tradicionais adotados na maioria das universidades. Além disso, a organização da ementa da disciplina implica, também,
1. Aluna de Doutorado do Programa de Pós-Graduaçāo em Ciências da Saúde da Universidade de Brasília.

2. Professora da Faculdade de Ciências da Saúde da Universidade de Brasília.

3. Professora do Curso de Enfermagem da Universidade Federal de Goiás.
Correspondencla:

Universidade de Brasília - Faculdade de Ciências da Saúde. Laboratório de Bioética e Ética em Pesquisa
Caixa Postal: 4554
Campus Universitário Darcy Ribeiro - Asa Norte Campus Universitário Darcy Ribeiro - Asa Norte
70910-900 - Brasília-DF Artigo recebido em 29/08/2013 Aprovado para publicaçāo em 24/03/2014 
em cuidado especial para que não seja apenas o novo nome das antigas disciplinas encarregadas dos aspectos disciplinares e legais das práticas profissionais. $\mathrm{O}$ processo ensino-aprendizagem da Bioética deve estar pautado na orientação para a tomada de decisões frente aos conflitos que se apresentam, tendo-se como preocupação a formação de profissionais éticos. ${ }^{6,7}$

No entanto, não existe nenhuma garantia de que o ensino da ética e da Bioética resultará em um comportamento mais ético por parte dos profissionais da área da saúde. Espera-se que o seu ensino durante a građuação amplie o raciocínio ético-moral por meio da reflexão de conflitos morais e clínicos presentes no cotidiano.

Após pouco mais de 40 anos do surgimento do termo bioética até o modo como o conhecemos nos dias atuais - que conta com uma rede global de pesquisadores, institucionali-zada e formalizada em matérias curriculares - é necessário questionar se esse conhecimento transmitido à nova geração de profissionais e pensadores tem sido eficaz no sentido de causar-lhes reflexão ou de impactar em suas tomadas de decisão. 8

A percepção das emoções dos estudantes diante dos conflitos vivenciados representa, também, fator importante no ensino da Bioética. Muitos profissionais da saúde ainda acreditam que para a escolha de uma decisão clínica ou ética, basta apenas o raciocínio lógico e que as emoções e sentimentos, nessas situações, demonstram uma atitude de fraqueza que não cabe no contexto profissional. Para a elaboração de opiniões, tanto morais e éticas quanto clínicas, sensações positivas ou negativas são afloradas e incorporam este processo. ${ }^{9}$

Diante do exposto, o objetivo deste estudo foi conhecer a prođução científica que explora sobre o ensino da Bioética no processo ensino-aprendizagem dos profissionais de saúde. $\mathrm{E}$ os objetivos secundários visa identificar as pesquisas mais recentes sobre a inclusão e a importância dessa disciplina nos cursos de graduação, quantificar a frequência dessas publicações e as revistas que mais publicam sobre o pelo tema.

\section{Motodologla}

Trata-se de um estudo exploratório, descritivo, no qual se utilizou a técnica de revisão sistemática para a coleta dos dados con duzida de maio a jultho de 2013.
Foram utilizadas bases de dados Medical Literature Analysis and Retrieval System Online (MEDLINE), Scientific Eletronic Library Online (SciELO), Literatura Latino-Americana e do Caribe em Ciências da Saúde (LILACS) e SciVerse Scopus (E1sevier). Em todas essas se usam descritores em saúde para realizar as pesquisas, sendo que na MEDLINE e Scopus usam-se os Medical Subject Headings (Mesh terms) e no Scielo e Lilacs os Descritores em Ciências da Saúde (Decs). Ambos permitem combiná-1os através de operadores boleanos OR, AND ou NOT, entretanto para este estudo foi utilizado o AND que seleciona artigos que contenham ambos os descritores.

A busca na base de dados MEDLINE utilizou as expressões "Bioethics" [Mesh] AND "Schools" [Mesh] e "Bioethics" [Mesh] AND "Teaching" [Mesh]. Essa busca ficou restrita aos artigos publicados no período de 2005 a 2013 e que permitissem o acesso livre ao texto completo.

$\mathrm{Na}$ base de dados SciELO e LILACS foram utilizadas as expressões: "Bioética" [Decs] AND "Instituições Acadêmicas" [Decs] e "Bioética" [Decs] AND "Ensino" [Decs]. A busca nessa base ficou restrita aos artigos publicados entre 2005 e 2013 e que também permitissem o acesso livre ao texto completo.

$\mathrm{Na}$ base de dados Scopus foram utilizadas as expressões "Bioethics" [Mesh] AND "Schools" [Mesch] e "Bioethics" [Mesh] AND "Teaching" $[M e s h]$. E a busca foi restrita aos artigos ou revisões publicados entre 2005 e 2013 com o filtro de subárea "Life Science" e "Health Science".

Esses temas foram pesquisados nos resumos de estudos nos idiomas espanhol, inglês e português e selecionados de acordo com os critérios de inclusão e exclusão.

Associando-se os descritores Bioética e Instituições Acadêmicas, foram encontrados 71 referências, sendo 9 (nove) na base de dados MEDLINE, 0 (zero) na SciELO, 0 (zero) na LILACS, 62 (sessenta e dois) na Scopus. Com a associação de descritores Bioética e Ensino foram encontradas 204 referências, sendo na MEDLINE 18 (dezoito), na SciELO 36 (trinta e cinco), na LIL.ACS 65 (sessenta e cinco) e na Scopus 86 (oitenta e seis).

Na primeira fase da pesquisa, realizou-se a leitura dos títulos dos artigos e dos resumos localizados. As publicações selecionadas obedeceram aos seguintes critérios de inclusão: trabalhos originais publicados em revistas e livros que contivessem dados sobre 
o ensino da disciplina de bioética durante a formação acadêmica do profissional de saúde; datados entre os anos de 2005 a 2013; e de domínio público (disponibilidade on-line). Foram também incluídos estudos publicados associados aos temas ensino de Bioética com a Ética, Deontologia e Ética Profissional.

Foram excluídos os artigos que não preencheram tais critérios, bem como textos repetidos (algumas revistas estão in dexadas em mais de uma base de dados); artigos in disponíveis na íntegra; estudos que não estivessem de acordo com os objetivos desta revisão, artigos de opinião e publicados em revista não indexada, dissertações, teses e livros-textos também foram excluídos da análise. Estudos com dados sobre o ensino de ética no ensino fundamental, médio e pósgrađuação também foram excluídos.

Os artigos foram classificados e analisados em relação ao título do artigo, curso de građuação, periódico de publicação e o ano de publicação. Foram utilizados também os critérios adaptados de Figueiredo, Garrafa \& Portillo $0^{5}$ e Baradó \& Guilhem ${ }^{11}$ para a análise do conteúdo: a) artigo original que se reserva à apresentação de resultado de pesquisas inéditas; foram incluídos as pesquisa de campo, estudos de caso e relato de experiência; b) artigo de revisão que incluem publicações que abordam, compilam, comparam ou analisam dados com base em estudos já existentes, sendo considerados os artigos de revisão sistemática e revisão de literatura; c) artigos de reflexão ou análises críticas, onde 0 autor apresenta seus pareceres sobre 0 assunto abordado $0^{5,11}$. Relatos de experiência no qual o autor expõe reflexão sobre o ensino da Ética e/ou Bioética também foram classificados como artigos de reflexão.

Os artigos originais, também considerados neste estudo como descritivos ou empíricos, foram apresentados quanto ao objetivo primário e os principais resultados, assim como os artigos de revisão sistemática. As análises dos artigos de revisão de literatura e reflexão foram expostos o objetivo primário e a conclusão.

Quanto à abordagem do estudo publicado, utilizou-se a seguinte categorização: a) Ensino da Bioética nos cursos de građuação em saúde; b) Ensino da Ética e/ou Deontologia e Ética profissional nos cursos de građuação em saúde; c) Ensino da Ética e Bioética nos cursos de građuação em saúde; d) Análise curricular da disciplina de Ética e/ou Bioética na formação em saúde, assim como sugestões para melhorias no ensino-aprendizagem de ambas; e) Atuação docente no ensino da Ética e/ou Bioética.

\section{Resultados}

De acordo com os critérios de busca, foram encontrados 276 (duzentos e setenta e seis) artigos científicos, onde inicialmente 157 (cento e cinquenta e sete) foram excluídos conforme ofluxograma abaixo (Figura 1). Foi então realizada uma leitura inicial dos títulos com o intuito de atender os objetivos da pesquisa e 71 (setenta e um) artigos foram excluídos. Após a leitura dos resumos e do texto, foram selecionados 38 (trinta e oito) artigos para análise (Figura 1).

A área com o maior número de publicações foi o curso de medicina com 16 (dezesseis) artigos $(42,10 \%)$, seguida pela enfermagem com 6 (seis) artigos $(15,78 \%)$ e Odontologia com 4 (quatro) publicações $(10,5 \%)$. Os cursos Ciências Biomédicas, Fonoaudiologia, Naturologia, Fisioterapia e Biologia apresentaram 1 (um) artigo cada (2,63\% cada). E 6 (seis) publicações $(15,78 \%)$ abrangeram todos os cursos de graduação em saúde ou somente dois ou três cursos com caráter multidisciplinar.

$O$ periódico com maior número de artigos selecionados foi Revista Brasileira de Educação Médica com 8 (oito) publicações $(21,05 \%)$. As revistas Bioética e $O$ Mundo da Saúde São Paulo apresentaram 3 (três) artigos cada (7,89\% cada). As demais revistas tiveram uma frequência de dois ou um artigo cada. A Tabela 1 apresenta a quantidade de artigos publicados por cada periódico.

O período de publicações variou de 2005 a jutho de 2013. 0 ano de 2009 apresentou o maior número de publicações, 9 (nove $-23,68 \%$ ). Seguida do ano de $2010 \operatorname{com} 8$ (oito-21,05\%). A Tabela 2 apresenta 0 ano de publicação dos artigos.

Quanto ao tipo de estudo, houve predomínio dos artigos originais, que apresentaram pesquisas de campo, estudos de caso ou relato de experiência, representando um total de 19 (dezenove) artigos (50\%). Foram encontrados também 13 (treze) artigos de reflexão/análise crítica $(34,21 \%)$ e 6 (seis) de revisão (15,78\%) (Tabela 2).

Quanto às categorias de abordagem, metade dos artigos analisou sobre o ensino da Bioética na građuação on đe enfatizaram sobre como a disciplina é abordada em cada curso ( $n=14 ; 36,84 \%$ ). Também foram encontrados artigos que analisaram sobre 0 ensino da Ética na graduação ( $\mathrm{n}=5 ; 13,15 \%)$ e artigos que analisaram tanto o ensino da Ética quanto o ensino da Bioética na formação acadêmica $(\mathrm{n}=9 ; 23,68 \%)$ (Tabela 2). 


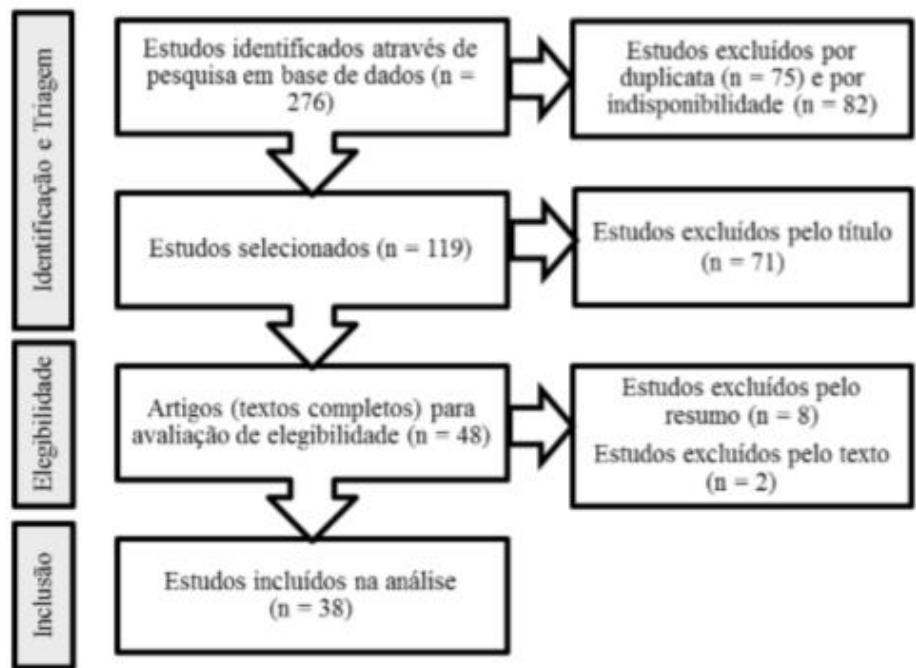

Figura 1: Fluxograma da Seleção de Artigos.

Tabela 1 - Relação dos Artigos Encontrados por Periódico de 2005 a julho de 2013.

\begin{tabular}{ll}
\hline Periódico & Quantidade de Artigos \\
\hline Revista Brasileira de Educação Médica & 8 \\
Revista Bioética & 3 \\
O Mundo da Saúde São Paulo & 3 \\
Acta Bioethica & 2 \\
Arquivos de Ciências da Saúde & 2 \\
Acta Paulista de Enfermagem & 2 \\
Revista Latino-americana de Bioética & 2 \\
Odontologia Clínico-Científica & 1 \\
Cogitare Enfermagem - UFPR & 1 \\
Revista Brasileira de Enfermagem & 1 \\
Revista Trabalho, Educação e Saúde & 1 \\
Revista Texto \& Contexto Enfermagem & 1 \\
Avances em Enfermaría & 1 \\
Revista Brasileira de Saúde Materno Infantil & 1 \\
Fisioterapia e Pesquisa & 1 \\
Cadernos Saúde Coletiva & 1 \\
Revista Ciência \& Saúde Coletiva & 1 \\
Interface & 1 \\
Journal of Medical Ethics & 1 \\
Journal of Evoluation in Clinical Practice & 1 \\
Psychosomatics & 1 \\
Cell Biology Education & 1 \\
Biotechnology \& Biotechnological Equipment & 1 \\
Total & 1 \\
\hline
\end{tabular}


Tabela 2 - Relação dos artigos encontrados segundo ano, autores, tipo de estudo e categorização - 2005 a julho 2013.

\begin{tabular}{|c|c|c|c|}
\hline Ano & Autoria & Estudo & Categoria \\
\hline \multirow[t]{2}{*}{2005} & Turrens, J. F. ${ }^{12}$ & Original & Bioética na Graduação \\
\hline & Roberts LW, et al. ${ }^{13}$ & Original & Análise Curricular \\
\hline \multirow[t]{2}{*}{2006} & Itai $\mathrm{K}$, et al. ${ }^{14}$ & Original & Atuação Docente \\
\hline & Ferreira HM, Ramos LH. ${ }^{15}$ & Reflexão & Ética e Bioética na Graduação \\
\hline \multirow[t]{2}{*}{2007} & Ramos FRS. ${ }^{16}$ & Revisão & Bioética na Graduação \\
\hline & Musse $\mathrm{JM}$, et al. ${ }^{17}$ & Original & Análise Curricular \\
\hline \multirow[t]{5}{*}{2008} & Oliveira GB, Guaiumi TJ, Cipullo JP. ${ }^{18}$ & Original & Bioética na Graduação \\
\hline & Badar6 AFV, Guilhem D. ${ }^{11}$ & Revisão & Ética e Bioética na Graduação \\
\hline & Correa FJL. ${ }^{19}$ & Reflexão & Atuação docente \\
\hline & Almeida AM, et al. ${ }^{20}$ & Original & Ética e Bioética na Graduação \\
\hline & Dantas F, Sousa EG ${ }^{1}$ & Revisão & Ética na Graduação \\
\hline \multirow[t]{9}{*}{2009} & Schuh CM, Albuquerque IM. ${ }^{21}$ & Reflexão & Ética na Graduação \\
\hline & Vieira PSPG Neves NMBC. ${ }^{22}$ & Original & Ética e Bioética na Graduação \\
\hline & Araújo $\mathrm{JL}$, et al. ${ }^{23}$ & Revisão & Ética e Bioética na Graduação \\
\hline & Siqueira JE. ${ }^{24}$ & Reflexão & Ética e Bioética na Graduação \\
\hline & Arakawa $\mathrm{AM}$, et al. ${ }^{25}$ & Original & Análise Curricular \\
\hline & Rupaya CRG ${ }^{26}$ & Original & Atuação docente \\
\hline & Kottow $\mathrm{MH}^{27}$ & Revisão & Bioética na Graduação \\
\hline & Silva RP, Ribeiro $\mathrm{VMB}^{28}$ & Reflexão & Bioética na Graduação \\
\hline & Novaes MRCG et al. ${ }^{29}$ & Original & Análise curricular \\
\hline \multirow[t]{8}{*}{2010} & D'Avila RL. ${ }^{30}$ & Reflexão & Ética e Bioética na Graduação \\
\hline & Costa SM, et al. ${ }^{31}$ & Original & Bioética na Graduação \\
\hline & Puplaksis NV, et al. ${ }^{32}$ & Original & Bioética na Graduação \\
\hline & Ramos FRS, et al. ${ }^{33}$ & Original & Atuação docente \\
\hline & Carneiro LAC, et al. ${ }^{34}$ & Revisão & Ética na Graduação \\
\hline & Mascarenhas NB, Rosa DOS. ${ }^{35}$ & Reflexão & Ética e Bioética na Graduação \\
\hline & Mascarenhas NB, Rosa DOS. ${ }^{36}$ & Original & Atuação docente \\
\hline & Oliveira AM. ${ }^{37}$ & Reflexão & Análise curricular \\
\hline \multirow[t]{4}{*}{2011} & Dantas AA, Martins CH, Militão MSR. ${ }^{38}$ & Reflexão & Bioética na Graduação \\
\hline & Cezar PHN, Gomes AP, Siqueira-Batista R. ${ }^{39}$ & Reflexão & Bioética na Graduação \\
\hline & Finkler M, Caetano JC, Ramos FRS. ${ }^{40}$ & Original & Bioética na Graduação \\
\hline & Pessalacia JDR, et a1 ${ }^{41}$ & Reflexão & Bioética na Graduação \\
\hline \multirow[t]{4}{*}{2012} & Gonzalez RF, Branco R. ${ }^{42}$ & Reflexão & Bioética na Graduação \\
\hline & Hellmann F, Verdi MIM. ${ }^{43}$ & Original & Bioética na Graduação \\
\hline & Kolarova TA, Denev ID. ${ }^{44}$ & Reflexão & Ética e Bioética na Graduação \\
\hline & Lipworth W, et al. ${ }^{45}$ & Original & Ética na Graduação \\
\hline \multirow[t]{2}{*}{2013} & Amorim KPC, Araujo EM. ${ }^{2}$ & Original & Ética na Graduação \\
\hline & Fernandes EF, Priel MR. ${ }^{7}$ & Original & Bioética na Graduação \\
\hline
\end{tabular}


Somente 5 (cinco) artigos analisaram como a disciplina de Bioética está inserida na matrizcurricular de cada instituição $(13,15 \%)$. E sobre a atuação docente no ensino da Bioética também foram encontrados 5 (cinco-13,15\%) os artigos (Tabela 2).
As tabelas abaixo apresentam os achados dos artigos originais (Tabela 3), revisão sistemática (Tabela 4), revisão da literatura (Tabela 5) e reflexão (Tabela 6).

Tabela 3: Relação dos artigos originais.

\begin{tabular}{lll}
\hline Autoria & Objetivo Primário & Resultados \\
\hline Turrens, J. F. ${ }^{12}$ & Descrever um curso de Bioética. & $\begin{array}{l}\text { Curso ajudou julgar e interpretar problemas } \\
\text { bioéticos e alunos estão menos propensos a }\end{array}$ \\
& $\begin{array}{l}\text { conclusões precipitadas. 40\%, depois do curso, } \\
\text { mais dificil tomar decisões éticas. }\end{array}$
\end{tabular}

Roberts LW, et al. ${ }^{13}$

Preparar os estudantes de medicina para questões éticas.

Itai $\mathrm{K}$, et al. ${ }^{14}$

Musse JM, et al ${ }^{17}$

Oliveira GB, Guaiumi TJ, Cipullo JP. ${ }^{18}$

Almeida AM, et al. ${ }^{20}$

Vieira PSPG, Neves NMBC. 22

Arakawa AM, et al. ${ }^{25}$

Rupaya CRG ${ }^{26}$

Novaes MRCG et al. ${ }^{29}$

Costa SM, et al. ${ }^{31}$
Demonstrar como docentes de bioética enfrentam discordância ética.

Identificar cursos de Odontologia com Bioética.

Caracterizar como é realizado o ensino da Bioética.

Avaliar o interesse e o conhecimento sobre ética médica e Bioética na graduação médica.

Panorama do interesse e do conhecimento sobre Ética Médica e Bioética.

Identificar cursos de Fonoaudiologia que apresentam a disciplina de bioética, ética e/ou deontologia.

Avaliar a formação ética e bioética do docente de uma Faculdade de Odontologia.

Analisar a inserção da ética e humanidades no currículo de Medicina.

Conhecer as percepções dos graduandos em relação aos conflitos bioéticos.
Interesse em domínios dos princípios da bioética, consentimento informado e cuidado de populações especiais.

A discordância ética na sala de aula depende do temae independe de origens sociais e individuais.

Dos 47 cursos, em São Paulo, 4 possuem

Bioética e é ministrada por docentes da área.

$92,7 \%$ respondeu que a Bioética estava no currículo e predomina aulas téricas $(72,3 \%)$.

O CEM foi lido por $86,2 \%$ dos professores,

$100 \%$ dos alunos. A importância dada à disciplina foi igual nos grupos.

O CEM foi lido por $97 \%$ dos professores e $96 \%$ dos alunos. A importância da disciplina foi 4.6 (professores) e 4,3 (alunos).

De 90 instituições, 60 possuíam endereço eletrônico, 9 não tinha o currículo, 9 não puderam ser acessadas, 5 não tinham o curso e 7 não constavam as disciplinas.

Amostra: 45 docentes de diversas áreas. Idade média 51 anos. A média de antiguidade na docência foi 15 anos e a maioria tinham crença religiosa $(97,8 \%)$.

Nas quatro primeiras séries, a inserção da temática humanização é superior.

Amostra: 60 alunos. Decisões do tratamento não é responsabilidade exclusiva do profissional; não deve ocultar diagnóstico do paciente. Não apóiam atestado falso e não respeitariam a vontade dos "Testemunha de Jeová". 
Puplaksis NV, et al.27

Verificar a contribuiçào da Bioética para a forna ação hunaanística do alunos.

Ramos FRS, et al. ${ }^{39}$

Caracterizar professores quanto a experiências e motivações para o ensino da ética e bioética na enfermagem.

Mascarenhas NB, Rosa $\operatorname{Dos}^{36}$

Identificar e descrever fontes bibliograficas usadas por docentes de Ética/Bioética em Enfermagem.

Finkler M, Caetano JC, Ramos FRS 40

Delinear um panorama đa formaçào ftica nos cursos de Odontologia brasileiros.

Discutir temas e referenciais de Bioética em Naturologia no Brasil
Identificar questồes éticas e profissio nais que não aparecent em curriculos padrão.

Identificar e analisar contéódos relacionados à inserçân da ética bioética na Medicina.

Compreender os impactos do ensino da Bioética em estudantes de Medicina.
Alunos: dificuldade nos primeiros atendimentos; despreparo na relação profissional-paciente, mas houve melhora após curso. Pacientes: aluno preocupado con seu bem estar; relacionamento aluno-professor bom.

A maioria possuia vinculo com instituiçẩ privada, dedicação exclusiva ou duplo vínculo. Onze querem contribuir com mudança e desenvolvimento da profissào.

Dos cinco cursos, os docentes adotam obras que contemplam a deontologia, exercicio profissional, fundamentos da Bioética e da Ética.

Há compronetimento com formaçào ética, capacitacioio docente, perfil do egresso $e$ integraçầo curricular. Deficiências de conteudos com formação cultural, humanistica e política, orientaçầo didática e ensino-aprendizagem.

Tenas: relaçåo terapêutica e orden ecol6gica. Quanto ans referenciais: cuidado, naturalista, virtudes, principialista, deontol6gica e social.

32 curriculos identificados e analisados. $O$ significado, valor da ética e profissionalismo coincidem nos curriculos, portem há aspectos do prática clínica săo ignoradas.

Releçào médico-paciente e exurrcício ilegal da medicina: temas mais frequentes.

O impacto đa Bioética na formsção đa nova geraçầ de nédicos ainda é baixo.

$\mathrm{MR}^{7}$

Tabela 4: Relação dos artiges de revisão sistemática.

\begin{tabular}{|c|c|c|}
\hline Autoria & Objetivo Primário & Resultados \\
\hline $\begin{array}{l}\text { Badar6 AFV, Grilhem } \\
\text { D. }{ }^{11}\end{array}$ & $\begin{array}{l}\text { Identificar temas relativos à Ética } \\
\text { e Biótica discutidos na } \\
\text { Fisioterapia. }\end{array}$ & $\begin{array}{l}23 \text { artigos, uma seção de revista e } 2 \text { editoriais. Predomi- } \\
\text { nou publicaçòes dos EUA e pesquisas de campo. } 16 \\
\text { artigns discutiram código de ética ou compartamentros } \\
\text { eticos. }\end{array}$ \\
\hline Dantas F, Sousa EG ${ }^{1}$ & $\begin{array}{l}\text { Avaliar a evoluçìo do ensino da } \\
\text { etica em escolas médicas brasilei- } \\
\text { ras. }\end{array}$ & $\begin{array}{l}\text { Estagnaçäo de disciplinas de ética nuédica, baixa carga } \\
\text { horária e número de docentes exclusivos. Responsabili- } \\
\text { dade e segredo profissional: temas abondados. Ensino: } \\
\text { aulas expositivas e điscussào de casos. }\end{array}$ \\
\hline Cameiro LAC, et al. ${ }^{34}$ & $\begin{array}{l}\text { Analisar o ensino da f́tica nos } \\
\text { cursos de graduagion cn saúde. }\end{array}$ & $\begin{array}{l}26 \text { artigos: predomina a Medicina. Conté6do: reflexb̉es } \\
\text { té6ricas e filos6ficas; aspectos pedag6́gicos e metodol6- } \\
\text { gicos; avaliação da aprendizagem da ética. }\end{array}$ \\
\hline
\end{tabular}


Tabela 5: Relação dos artigos de revisão da literatura.

\begin{tabular}{lll}
\hline Autoria & Objetivo Primário & Conclusão \\
\hline Ramos FRS. $^{16}$ & $\begin{array}{l}\text { Analisar a constituição histórica } \\
\text { do discurso da bioética. }\end{array}$ & $\begin{array}{l}\text { ABioética gera determinados modos de conceber e inter- } \\
\text { vir do sujeito trabalhador em saúde. }\end{array}$ \\
${\text { Araújo JL, et al. }{ }^{23}}^{23}$ & $\begin{array}{l}\text { Refletir sobre ensino da ética/ } \\
\text { bioética e as Diretrizes Curricula- } \\
\text { res em Enfermagem. }\end{array}$ & $\begin{array}{l}\text { Desafios: formação e capacitação docente; transversalidade } \\
\text { da ética; definição do marco térico-conceitual; articula- } \\
\text { ção do conteúdo com a prática; adoção de metodologia } \\
\text { problematizadora. }\end{array}$ \\
Kottow MH. ${ }^{27}$ & $\begin{array}{l}\text { Elaborar oferta didática com bases } \\
\text { bioéticas aconselháveis para curso } \\
\text { de medicina. }\end{array}$ & $\begin{array}{l}\text { Programas variam de 5-10 aulas, máximo 200 horas em } \\
\text { semestres básicos ou clínicos. Métodos de ensino diver- } \\
\text { sos, quase todos aula magistral e discussão. Preferência } \\
\text { por docência interativa, não há professores suficientes. Na } \\
\text { avaliação, maioria ensaio breve e casos esquemáticos. }\end{array}$ \\
\hline
\end{tabular}

Tabela 6: Relação dos artigos de reflexão.

\begin{tabular}{lll} 
Autoria & Objetivo Primário & Conclusão \\
\hline Ferreira HM, & Elaborar propostas para a educação & $\begin{array}{l}\text { Necessidade de planejar e sistematizar o ensino da éti- } \\
\text { ca/bioética para que o aluno tome decisões autônomas }\end{array}$ \\
Ramos LH. ${ }^{15}$ & e reflexivas.
\end{tabular}

Correa FJL. ${ }^{19} \quad$ Apresentar experiências docentes e reflexões sobre como ensinar Bioética.

$\begin{array}{ll}\text { Schuh CM, } & \text { Apontar razões para sustentar a } \\ \text { Albuquerque IM } 21 & \text { necessidade do ensino da ética }\end{array}$ saúde.

Siqueira JE. ${ }^{24}$

Discutir as alternativas de ensino de ética e bioética na medicina.

Silva RP, Ribeiro

$\mathrm{VMB}^{28}$

Sistematizar o estado da arte do ensino da bioética na graduação médica.

D'Avila RL. ${ }^{30}$

Estimular o debate sobre possibilidades e limites do ensino da moral.

Mascarenhas NB, Reunir conceitos da bioética e refletir Rosa DOS. ${ }^{35}$
Necessita-se participação ativa e reflexiva sobre comportamento estudantil, conforme regulamentos, Declaração de Direitos Humanos, Constitucionais e Pedagógicos e princípios éticos.

Instituições de ensino superior são importantes na disseminação de conteúdos éticos pertinentes a cada profissão. O ensino da ética visa humanização da prática médica.

O modelo atual de ensino deve mudar. Mas, não somente alterações programáticas, e sim mudanças de professores e alunos sobre conhecimento e transmissão de valores.

Educação e trabalho médico devem estar associados. Isso justifica a inserção da bioética nos cursos de Medicina, como inovação curricular.

Necessidade da formação moral, embora há limitação em alcança-1a, incapaz de transformar determinadas mentes.

O ensino requer associar a vivência prática. Para formar enfermeiros reflexivos devem-se usar metodologias ativas. Docentes necessitam ampliar conhecimentos filosoficos. 
Oliveira $\mathrm{AM}^{37}$

Analisar aspectos bioéticos contidos nas Diretrizes Curriculares da Medici-

Dantas AA,

Martins $\mathrm{CH}$

Militão MSR. ${ }^{38}$

Inserir disciplinas de humanidades com abordagem de tema bioético usando o cinema.

Pessalacia JDR, et al $4^{41}$

Relatar experiência sobre inserção da ética e bioética no currículo de enfermagem.

Gonzalez RF, Branco R ${ }^{42}$

Abordar o processo ensino-aprendizagem da relação médico-paciente.

Kolarova TA, Denev ID. ${ }^{44}$
Justificar a inclusão da Bioética na Biologia.
A bioética está nas diretrizes curriculares. Resta ao aparelho formador garantir que a bioética se consolide na academia.

O cinema pode ser uma ferramenta educacional, pois ao desvelar experiências vividas por personagens, motiva o aluno acompanhar histórias que não experimentaram (ou irão experimentar).

O conteúdo de Bioética encontra-se em todas as unidades curriculares e abrange situações dilemáticas do cuidar. Propicia desenvolver atitudes autônomas e re flexivas.

A relação exige conhecimentos, habilidades e atitudes que devem ser desenvolvidas durante o curso. A Bioética pode colaborar nisso.

$\mathrm{O}$ aluno torna consciente da importância da biologia para a sociedade e aplica princípios éticos. ABioética o forma com competências e habilidades.

\section{Discussão}

Os resultados encontrados demonstram que existe uma diversidade de publicações científicas re lacionadas com o ensino e a Bioética. Entretanto, no que diz respeito às pesquisas sobre o processo-aprendizagem da Bioética como disciplina fundamental para a formação do profissional da saúde verifica-se que os estudos são limitados. Tal fato se constatou pela quantidade de artigos excluídos por não apresentarem relação direta com o objetivo deste estudo. Nestes, verificou-se que a temática era abordada sem um aprofundamento do tema. E em alguns, o título do texto parecia pertinente ao estudo, porém o enfoque de abordagem dos resumos e do texto era outro.

Entretanto, a preocupação com a Bioética e seu fortalecimento como disciplina nos cursos de graduação na área da saúde é facilmente percebida devido ao número de artigos publicados que faz referência à disciplina emseu contexto curricular ou mesmo a forma como é tratada durante os cursos de formação profissional. Há uma preocupação aparente em que o tema seja abordado para além dos códigos de deontologia/ética de cada profissão, e que auxilie em uma formação mais ampla, contemplando aspectos do comportamento ético e a tomada de decisão.

Constatou-se também que apesar da existência de uma quantidade relativa de periódicos relaciona- dos com a Bioética, ainda são restritas as revistas indexadas nos principais bancos de dados nacionais internacionais que priorizam a publicação de artigos que apresentam sobre a temática. De acordo com a Tabela 1, verifica-se que as publicações resumiramse a vinte e três tipos de periódicos, entretanto, a grande maioria delas só foi encontrado um artigo sobre o ensino da Bioética.

Quanto ao número de prođução científica, um dos pontos relevantes a ser discutido é o fato de que entre os 38 artigos selecionados, mais da metade foram publicados durante o período de 2009 a 2010 Embora o Código de Nuremberg (1947), a Declaração dos Direitos Humanos (1948) e a Declaração de Helsinque (1964) ser considerados balizas do nascimento da bioética como disciplina, no Brasil a normatização da Bioética no sentido disciplinar se dev com o desenvolvimento científico e tecnológico do país na década de 80 e sofreu um incremento acelerado nos anos de 1990 com a criação dos Comitês de Ética e Pesquisa. ${ }^{3,4,46}$ Dessa forma, os resultados da pesquisa revelaram que a discussão sobre o ensino em Bioética na građuação é recente.

Outro fator que também pode justificar os anos de 2009 e 2010 apresentarem o maior número de publicações é a crescente preocupação de estudantes e professores da área da saúde quanto à formação profissional, assim como no julgamento e interpretação 
dos problemas bioéticos. ${ }^{12} \mathrm{E}$ torna-se relevante ressaltar que alguns artigos colocam como desafios éticos atuais, além da necessidade de construção de artigos específicos, a escassa formação de docentes na área de Bioética e a forma como a disciplina é ministrada $1,18,27,35,40$

Ao relacionar as áreas acadêmicas com o número de artigos publicados, verifica-se que essa preocupação permanece na área médica, pois a soma dos estudos identificados ultrapassa o total dos artigos publicados por outros profissionais da área da saúde.

Entretanto, isso não implica em dizer que não há preocupação com Bioética nos demais cursos, mas que o debate deve ser sustentado na transdisciplinariedade, trazendo todos para uma construção coletiva que permita a construção de comportamentos éticos in dependente das circunstâncias encontradas emnossas práticas profissionais, que jamais são isoladas e fragmentadas.

Observa-se também que o maior número de publicações é de estudos originais, sendo consideradas, neste estudo, as pesquisas de campo, estudos de casos e relatos de experiência. Ao analisar estes estudos pode-se observar uma maior concentração de publicações de texto onde houve a aplicação de questionários e entrevistas.

A atuação docente no ensino da Bioética foi abordada em cinco artigos encontrados. Pode-se considerar que são poucos estudos sobre aqueles que se dispõe a atuar nesse campo. Este fato pode estar associado há uma necessidade de atualização mensal sobre 0 tema. Entretanto, grande parte dos professores, raramente ou no mínimo anualmente, se atualiza sobre o assunto. Este é um dado de grande importância, visto que os professores devem estar a par das novidades referentes à Ética e Bioética, porque, de um modo geral, eles são tidos como modelos para seus alunos. ${ }^{22}$

O maior desafio, hoje, é vencer a carência de profissionais qualificados para os ensinamentos em Bioética. Lidar com todos os temas que envolvem valores, costumes, direitos, limites, responsabilidade social, nos quais a ciência, a vida e a ética interagem entre si, é in đispensável uma qualificação e formação multidisciplinar, assim como a experiência prática em Comitês de Ética. ${ }^{47}$

Diante dos dados analisados, acredita-se que existam artigos não publicados ou em revistas não indexadas relacionadas ao tema da Bioética como disciplina. Talvez uma metodologia de busca mais ampla, em um período mais prolongado, com palavraschaves diferenciadas, poderia aumentar o número de artigos selecionados. Essa foi uma limitação deste estudo que foi considerada ao discutir tais resultados. No primeiro estudo encontrado Turrens ${ }^{12}(2005)$ apresentou dados em que $80 \%$ dos alunos que cursaram a disciplina de Bioética afirmaram que a mesma ajudou a aprender como julgar e interpretar alguns problemas do dia-a-dia e que eles estariam menos propensos a tirar conclusões precipitadas. $\mathrm{E}$ ao mesmo tempo, cerca de $40 \%$ dos estudantes indicou que, depois de fazer este curso, era mais difícil para eles a tomar decisões éticas. $\mathbf{O}$ autor justifica que uma das razões para esta dificuldade é que o curso ensinou-os a avaliar e tentar identificar algo positivo em todas as situações clínicas evidenciadas, e que eles não estavam acostumados a fazer isso antes do curso.

Musse $^{17}(2007)$ afirma que um curso teórico de introdução a Bioética deveria ser iniciado ainda no ciclo básico da formação de nível superior. Mas de acordo com seu estudo, de âmbito regional, pôde observar que nos 47 cursos de Odontologia das faculdades pesquisadas, somente quatro apresentavam a disciplina na grade curricular. E a mesma era oferecida apenas na metade final do curso, momento no qual esses conhecimentos deveriam estar solificados, uma vez que influenciarão a conduta dos futuros profíssionais durante toda sua vida. $\mathbf{O}$ autor ain da complementa que o ensino da Bioética de forma isolada, por meio de metodologia convencional de transmissão passiva do conhecimento é inviável e que deve ocupar todos os momentos possiveis da formação profissional.

A bioética como disciplina pode auxiliar no enfrentamento de situações de difícil mediação moral como o fim da vida, a morte, a negligência, dentre outras. O campo de influência da Bioética perpassa praticamente todas as áreas acadêmicas, inserindo-se no contexto internacional como referencial teórico que instiga à análise e discussão de dilemas morais de amplo espectro. Como não poderia deixar de ser, ela emerge também no panorama eđucacional, contribuindo para a compreensão dos problemas éticos historicamente persistentes, que ainda não foram solucionados, e emergentes, que fazem parte dos novos desafios do século XXI. ${ }^{18}$

No mesmo sentido, Novaes et $\mathrm{al}^{29}(2010)$ analisou a importância da inserção curricular das temáticas da ética, bioética e humanização na formação médica nas séries iniciais do cursos. $\mathrm{E}$ concluiv que tal fato foi essencial para garantir as competências necessárias ao exercício profissional, facilitada mediante aplicação de estratégias metodológicas ativas que buscam a reflexão sobre o tema. 
Puplaksis et al ${ }^{32}$ (2010) diz que o processo do apren dizado da bioética parece estar truncado se não há uma continuidade de reflexão e do exercício de aplicação dos valores em questão a casos concretos, sendo necessário envolver o ensino da bioética numa forma transversal em todos os níveis de formação da građuação, tanto do pessoal médico, como dos profissionais de saúde.

Ferreira \& $\operatorname{Ramos}^{15}$ (2006) em seu artigo de reflexão diz que todos os profissionais da área da saúde vivenciam constantemente desafios e conflitos éticos em sua prática cotidiana e a reflexão sobre essas situações carecem de uma discussão mais aprofundada que thes permita esse enfrentamento, bem como o desenvolvimento de atitudes e posturas éticas a partir do referencial fornecido pelas teorias bioéticas. Autilização desse conhecimento, a fun đamentação requerida e sua aplicação estão bem mais evidenciadas nos cursos de medicina e de enfermagem.

A formação dos profissionais da saúde ainda carece de maior investimento sobre a utilização dos fundamentos da Bioética, principalmente no que diz respeito à relação com o paciente. Para alcançar esses objetivos torna-se in dispensável que as instituições adequem os programas curriculares de graduação, com vistas a proporcionar conhecimento e reflexão sobre o tema de forma contínua. Diante disso, Badaró \& Guilhem ${ }^{11}$ (2008), em um artigo de revisão, afirma que os educadores precisam se preparar para enfrentar esse desafio.

O ensino da Bioética trata de uma área de discussão, reflexão e interação entre pessoas que estejam interessadas em debater e estabelecer hierarquias de valores, incluindo a visão moral, as decisões, as condutas e as políticas. ${ }^{5,17} \mathrm{~A}$ Bioética vem sendo cada vez mais importante na formação moral e na tomada de decisões do profissional de saúde, pois há uma necessidade de prepará-lo para o enfrentamento de conflitos éticos que as mudanças no perfil epidemiológico da saúde estão provocando, bem como aos avanços provenientes do desenvolvimento científico e tecnológico. ${ }^{11}$

Dantas, Martins \& Militão $0^{38}$ (2011), em um artigo de reflexão, sugerem que o cinema pode contribuir para uma ferramenta educacional importante, pois, ao desvelar experiências vividas por personagens, motiva os estudantes a acompanhar histórias de vida que ainda não experimentaram ou que irão experimentar.
Todos os profissionais de saúde devemser sensíveis às questões éticas. $\mathrm{O}$ ensino da bioética, de acordo com Kolarova \& Denev ${ }^{44}$ (2012) deve ser baseado em abordagem reflexiva constante sobre questões éticas, a fim de desenvolver nos futuros profissionais a competência para agir moralmente e socialmente de forma responsável em situações ađversas. Dessa forma, é importante a elaboração de estratégias de intervenção e reflexão a partir da prática docente. ${ }^{2}$

\section{Conclusão}

Pôde-se observar que existe unanimidade entre os autores quanto à importância da disciplina de Bioética o desenvolvimento moral e ético do estudante. Isso ocorre devido à necessidade de preparar os futuros profissionais para enfrentar as diversas situações com os quais vão se deparar ao longo da experiência profissional.

Como forma de minimizar conflitos éticos durante a atuação profissional - seja nos estágios supervisionados ou mesmo após a formação superior - os educadores podem incluir durante suas exposições, debates e seminários em sala de aula, estudos de caso baseados em situações concretas e persistentes encontradas nas práticas clínicas da profissão, filmes que evidenciam situações conflitu osas e com isso estimular o aluno a julgar, raciocinar e tomar a decisão que ele considerar mais acertadas sem excluir o valor sentimental.

Para alcançar esse objetivo é essencial que as instituições que oferecem os cursos dasaúde adequem as ementas da disciplina Bioética e estimulem uma aproximação precoce dos estudantes com esses temas por meio de cursos, jornadas, congressos e pesquisas durante toda a sua formação acadêmica. Por outro lado, é de fundamental importância incitar os professores a buscar capacitação técnica, teórica e vivência clínica uma vez que os educadores serão os espelhos e exemplos dos futuros profissionais de saúde.

No entanto, persiste a necessidade de maior discussão sobre a importância da Bioética na formação acadêmica, pois a identificação e 0 enfrentamento dos conflitos éticos são distintos a depender de cada profissão. Dessa forma, torna-se imperativo o desenvolvimento de estudos mais amplos sobre reflexões bioéticas específicas para a formação dos profissionais de cada área da saúde, promovendo a eđucação permanente, resguardando o lócus da construção transdisciplinar. 


\begin{abstract}
Study Design: Sistem atic Review of literature. Aims: To know the scientific production that explore on the teaching of Bioethics in the teaching learning for health professionals. Metho dology: Exploratory study to identify article on the teaching of bioethics in undergraduate health professional, published from 2005 to July 2013, published in Portuguese, English and Spanish languages. Results: 38 articles had been selected, with the biggest publication number in 2009, in the area of medicine, with a predominance of original/em pirical articles $(50 \%)$. The majority of selected articles pointed out the teaching of bioethics for undergraduate courses in the health area $(n=14 ; 36.84 \%)$. Conclusion: In accordance with the results obtained by this research, it was found an agreement between authors related to the in portance to introduce the discipline Bioethics in the curriculum matrix for the undergraduate courses on the health area.
\end{abstract}

Key-Words: Bioethics. Curriculum. Teaching. Schools. Decision Making.

\section{Rofor\&nclas Blbilografilcas}

1. Dantas F, Sousa EG. Ensino da Deontologia, Ética Médica e Bioética nas Escolas Médicas Brasileiras: uma revisão sistemática. Rev Bras Educ Med. 2008; 32: 507-17.

2. Amorim KPC, Araújo EM. Formaçāo ética e humana no curso de medicina da UFRN: uma Análise Crítica. Rev Bras Educ Med. 2013; 37: 138-48.

3. Diniz D. Sugai A, Guilhem D, Squinca F. Ética em pesquisa: tem as globais. $1^{\text {nd }}$. ed. Brasília: Editora UnB; 2008 .

4. Badaró AFV. Ética e Bioética na Práxis da Fisioterapia: Des vendando comportamentos. [Tese de Doutorado]. Brasília: Faculdade de Saúde - UnB; 2008.

5. Figueiredo AM, Garrafa V. Portillo JAC. Ensino da Bioética na área das Ciências da Saúde no Brasil: Estudo de Revisấo Sistemática. Rev INTER thes is 2008; 5; 47-72.

6. Carvalho FT, Muller MC, Ramos MC. Ensino à distância: uma proposta de ampliaçāo do estudo em bioética. DST-J Bras Doenças Sex. Trasm 2005; 17: 211-4.

7. Anjos MF. Introduçāo. In: Anjos MF, Siqueira JE. Bioética no Brasil tendências e perspectivas. $1^{\text {na }}$. ed. São Paulo: Idéias \& letras; 2007

8. Fernandes EF, Priel MR. O ensino da Bioética e a tomada de decisōes: impacto em estudantes de medicina. O Mundo da Saúde Sāo Paulo 2013; 37: 9-15.

9. Greenfiel BH. The meaning of caring in five experience physical therapists. Physiother Theory Pract 2006; 22: 17587.

10. Badaró AFV Guilhem D. Bioética e pesquisa na Fisioter apia: aproximação e vínculos. Fisioterapia e Pesquisa 2008; 15 : 402-7.

11. Turrens $\mathrm{JF}$. Teaching research integrity and bioethics to Science undergraduates. Cell Biology Education 2005; 4: 330-4.

12. Roberts LWR, Geppert CMA Warner TD, Hammond KAG Lamberton $\sqcup$. Bioethics principles, informed consent, and Ethical care for special populacions: Curricular needs expressed by Men and Wom an Physicians-in-Thaining. Psychosomatics 2005; 46: 440-50.

13. ItaiK Asai A Tsuchiya Y OnishiM KosugiS. How do bioethics teachers in Japan cope with ethical disagreement among healthcare university students in the classroom? A survey on educators in charge. J Med Ethics 2006; 32: 303-8.

14. Ferreira HM, Ramos $\sqcup H$. Diret izes curriculares para o ensino da ética na graduação em enfermagem. Acta Paul Enferm 2006; 19: 328-31.
15. Ramos, FRS. O discurso da Bioética na formaçẫo do sujeito trabalhador da saúde. Trabalho, Educação e Saúde 2007; 5 : 51-77.

16. Musse JO, Boing AF, Martino FS, Silva RHA, Vaccarezza GF, Ramos DiP. O ensino da bioética nos cursos de graduaçāo em odontologia do estado de São Paulo. Arq Ciênc Saúde 2007; 14: 13-6.

17. Oliveira GB, Guaiumi TJ, Cipullo JP. Avaliaçāo do ensino de Bioética nas faculdades de medicina do estado de São Paulo. Arq Ciênc Saúde 2008; 15: 125-31.

18. Correa FJL. Enseñar bioética: como transmitir conocim ientos, actitudes y valores. Acta Bioeth 2008; 14: 11-8.

19. Almeida AM, Bitencourt AGV, Neves NMBC, Lordelo MR, Lemos KM, Nuñez GR, et al. Conhecimento e Interesse em ética médica e bioética na graduação médica. RevBras Educ Med 2008; 32: 437-44

20. Schuh CM. Albuquerque IM. A ética na formação dos profissionais da saúde: algum as reflexōes. Rev bioét 2009 ; 17: $55-60$.

21. Vieira PSPG, Neves NMBC. Ética médica e bioética no curso médico sob o olhar dos docentes e discentes. 0 mundo da Saúde Sāo Paulo 2009; 33: 21-5.

22. Araújo JL, Jorge MSB, Freitas CHA, Moreira TMM. O ensino da ética e da bioética no processo de form açāo do enfermeiro frente às diretrizes curriculares nacionais. Cogitare Enferm 2009; $14: 559-63$

23. Siqueira JE. O ensino da ética no curso de medicina. O mundo da Saúde São Paulo 2009; 33: 8-20.

24. Arakawa AM, Santos CC. Carleto NG, Sales-Peres A, SalesPeres SHC. O ensino da Ética, Bioética e Deontologia na graduaçāo de Fonoaudiologia. Cad Saúde Colet 2009; 17 : 529-44.

25. Rupaya CRG Conocimientos de ética y bioética del odontólogo en el ámbito de la actividad docente. Revista Latinoamericana de Bioética 2009; 9: 70-5.

26. KottowMH. Enseñanza de la Bioética: una sínteses. RevBras Educ Méd 2009; 33: 658-63.

27. Silva RP, Ribeiro MMB. Inovaçãa curricular nos cursos de graduação em Medicina: 0 ensino da bioética como uma possibilidade. Rev Bras Educ Med 2009; 33: 134-43.

28. Novaes MRCG, Novaes LCG Guilhem D, Lolas F, Silveira C, Guiotti M. Inserção dos temas de humanidades e ética em currículo médico integrado em Escola Pública no Distrito Federal, Brasil. Acta Bioeth 2009; 15: 202-11. 
29. D'Ávila RL. A ética médica e a bioética como requisitos do ser moral: ensinando habilidades humanitárias em medicina. Rev bioét 2010; 18: 311-27.

30. Costa SM, Canela JR, Drumond JGF, Dias OV, Santa TTA. Implicaçōes bioétic as na relação profissional de saúde e usuários: estudo junto aos acadêmicos dos cursos de saúde na Unimontes. Odontol Clin-Cient 2010; 9: 263-7.

31. Puplaksis NV, Silva MMP, Nobile R, Ramos DLP. A disciplina de Bioética na Faculdade de Odontologia da Universidade de São Paulo. Revista Latinoamericana de Bioética 2010; 10: $68-75$.

32. Ramos FRS, Schoeller SD, Brehmer LCF, Am aral RFC, Melo TAP. Motivaçōes e experiências do ensino da ética/bioética em enfermagem. Av Enferm 2010; XXVIII: 40-7.

33. Carneiro LA, Porto CC, Duarte SBR, Chaveiro N. Barbosa MA. O ensino da ética nos cursos de graduação da área de saúde. Rev Bras Educ Med 2010; 34: 412-21.

34. Mascarenhas NB, Rosa DOS. Bioética e Formaçāo do Enfermeiro: Uma interface necessária. Texto Contexto Enferm 2010; 19: 366-71

35. Mascarenhas NB, Rosa DOS. Ensino da Bioética na formaçāo do enfermeiro: interface com a bibliografia adotada. Acta P̧ầo do enfermeiro: interface conferm 2010; 23: 392-8.

36. Oliveira AM. Bioética e as diretrizes curriculares nacionais do curso de medicina. Rev Bras Saúde Matern Infant 2010; 10 : S303-9.

37. Dantas AA, Martins CH, Militāo MSR. O cinema como instrumento didático para a abordagem de problemas bioéticos: uma reflexāo sobre a eutanásia. Rev Bras Edu Med 2011; 35: 69-76.
38. Cezar PHN Gomes AP Siqueira-Batista R. O cinema e a educaçāo bioética no curso de graduaçāo em medicina. Rev Bras Educ Med 2011; 35: 93-101.

39. Finkler M, Verdi MIM, Caetano JC, Ramos FRS. Formaçāo profissional ética: um compromisso a partir das diretrizes curriculares. Trab Educ Saúde 2011; 8: 449-62.

40. Pessalacia JDR, Oliveira VC, Rennó HMS, Guim arāes EAA. Perspectivas do ensino de bioética na graduação em enfermagem. Rev Bras Enferm 2011;64: 393-8.

41. Gonzalez RF, Branco R. Reflexōes sobre o processo ensinoaprendizagem da relaçāo médico-paciente. Rev bioét 2012;20: 244-54

42. Hellmann F, Verdi MIM. Temas e referenciais de análise em Bioética no ensino da graduaçãa em Naturologia no Brasil à luz da Bioética social. Interface - Comunic., Saude, Educ 2012; 16: 733-47.

43. Kolarova TA, Denev ID. Integrating a Bioethics course into undergr aduate biology education. Biothechnol. \& Biotechnol. Eq 2012; 26: 2801-10

44. Lipworth W, Kerridge I, Little M, Gordon J, Markham P. Meaning and value in medical school curricula J Eval Clin Pract 2012 18: $1027-35$

45. Guerriero ICZ, Schmidt MLS. Zicker F. Ética nas Pesquisas em Ciências Humanas e Sociais na Saúde. $2^{\text {nde }}$.ed. São Paulo: Hucitec, 2008

46. Caicedo CB. Necessidad de la Bioética em la Educación superior. Acta Bioeth 2006; 12: 35-40. 


\section{Artigo 2 - Ética e Bioética no Contexto da Fisioterapia}

Artigo aceito para publicação pela Revista Fisioterapia e Pesquisa.

Este artigo que está em acordo com o objetivo específico deste estudo que foi realizar uma revisão sistematizada sobre a disciplina de bioética no contexto da formação acadêmica do fisioterapeuta. 


\section{ÉTICA E BIOÉTICA NO CONTEXTO DA FISIOTERAPIA}

Leticia Martins Paiva, Dirce Guilhem, Maria Rita Carvalho Garbi Novaes

\section{RESUMO}

O objetivo deste estudo foi analisar as publicações sobre ética e bioética considerando sua importância para a prática, ensino e pesquisa em fisioterapia. Trata-se de um estudo exploratório, utilizando-se técnica de revisão sistemática da literatura, realizado entre junho e novembro de 2014. Foram incluídos artigos sobre o tema que estivessem disponíveis eletronicamente, excluindo-se textos duplicados, indisponíveis e que se desviavam do assunto. Foram selecionados 23 artigos. O periódico com maior número de publicações foi a revista Physical Therapy. Os anos 2010, 2011 e 2013 registraram maior número de publicações. As modalidades de artigos mais frequentes foram artigos originais. Os dados demonstraram número reduzido de publicações associando ética e bioética à fisioterapia. Evidencia-se a necessidade de aprofundar a discussão e criar linhas específicas de investigação sobre esta temática.

Palavras-chave: Ética; Bioética; Fisioterapia; Prática profissional; Reabilitação.

\section{ABSTRACT}

The objective was to analyze the publications on ethics and bioethics considering their importance for practice, teaching and research in the context of physical therapy. It is exploratory study, using the technique of systematic review of the literature, conducted in June and November of 2014. The articles on the subject that were available electronically, discarding duplicates, unavailable texts and deviants of the matter were included. There were selected 25 articles. The academic journal with the highest number of publications was the Physical Therapy. The years 2010, 2011 and 2013 registered the largest number of publications. Modalities of articles more prevalent were originals article. The data pointed out reduced number of publications linking ethics and bioethics to physiotherapy. This evidence confirms the need to deepen the discussion and create specific lines of research on this topic.

Keywords. Ethics; Bioethics; Physical therapy specialties; Professional practice; Rehabilitation. 
A ética na saúde é ciência que favorece o respeito aos direitos dos pacientes e contribui para o desenvolvimento de habilidades e atitudes para a mediação de conflitos que emergem da prática profissional cotidiana ${ }^{1,2}$. A Bioética, conceituada como estudo da conduta humana na área das ciências da vida, as relações do homem com os outros seres vivos e os cuidados à saúde, é fruto da preocupação com o destino da humanidade e às gerações futuras ${ }^{3,4,5}$.

O vínculo entre ética, bioética e Fisioterapia é recente e em caminho de consolidação. Esse conhecimento incorpora saberes multidisciplinares e interdisciplinares essenciais para todas as carreiras da saúde. Inclui contínuo e crescente processo de evolução fundamentadas em conhecimentos da antiguidade adaptados aos contextos atuais ${ }^{6,7}$.

A Fisioterapia e a prática do fisioterapeuta objetivam preservar, manter, desenvolver, restaurar ou reabilitar a integridade da pessoa considerando seu entorno e rede de apoio social ${ }^{8}$. Nas últimas quatro décadas a profissão ampliou progressivamente suas responsabilidades e seu foco na autonomia profissional e na prática clínica baseada em evidências ${ }^{9}$.

Esta autonomia é fundamental para 0 atendimento das expectativas da sociedade e das exigências de competência profissional e ética ${ }^{9}$. No Código de Ética da Fisioterapia e Terapia Ocupacional a autonomia agrega conteúdos bioéticos, está centrada no profissional, caracterizando o fisioterapeuta como o lado mais forte da relação terapeuta-paciente ${ }^{10}$.

O exercício da autonomia é um marco na evolução da profissão. Trouxe dilemas e responsabilidades éticas mais complexas considerando-se as tensões vivenciadas no cenário das práticas de saúde, ainda hoje pouco conhecidas e discutidas. Incluem descompasso entre tratamentos propostos e resultados alcançados, proximidade física na interação terapeuta-paciente, falhas nos encaminhamentos dos pacientes para a reabilitação e conflitos éticos durante os atendimentos ${ }^{6,11,12}$.

O conhecimento sobre ética e bioética representa requisito fundamental para 0 desenvolvimento profissional. Vincula-se à consolidação da profissão e o avanço científico e tecnológico. A produção científica brasileira e internacional aborda esses temas, mas trata de forma incipiente o processo de tomada de decisão, restringindoo à relação terapeuta- ${ }^{13}$. 
O objetivo deste artigo foi analisar as publicações sobre ética e bioética considerando sua importância para a prática, ensino e pesquisa no contexto da fisioterapia.

\section{Material e Métodos}

Estudo exploratório, efetuado por meio de revisão sistemática realizada de junho a novembro de 2014. Foi efetuada pesquisa em bases de dados eletrônicas, selecionando-se artigos publicados entre 2004 a novembro de 2014.

Definiram-se como critérios de inclusão: artigos com temas relacionados ao vínculo entre ética, bioética e Fisioterapia, de domínio público e disponíveis em formato eletrônico. Foram excluídos livros-textos, artigos em revistas não indexadas, editoriais e artigos de opinião.

A busca eletrônica foi efetuada nas bases de dados MEDLINE, SciELO, Lilacs, BVS - Biblioteca Virtual em Saúde e BVSMS - Biblioteca Virtual em Saúde do Ministério da Saúde. Foram utilizadas associações de descritores do DECS (Descritores em Ciências da Saúde da Biblioteca Virtual em Saúde), em português, inglês e espanhol: ética e fisioterapia; bioética e fisioterapia; ética e reabilitação; bioética e reabilitação, definidos para alcançar o objetivo proposto. Foi efetuada busca desses temas nos títulos e/ou resumos e examinados de acordo com os critérios de inclusão e exclusão.

Inicialmente, os artigos selecionados foram organizados de acordo com o ano de publicação, base de dados, revista indexada, título e tipo de pesquisa. Após, foi realizada análise descritiva e categorização de cada estudo de acordo com o tipo de pesquisa e abordagem do tema.

Foram classificados utilizando-se critérios adaptados de Badaró \& Guilhem ${ }^{14}$ para a análise do conteúdo: a) artigo de revisão: revisão sistemática e de literatura que analisaram dados de estudos existentes; b) artigo original: pesquisa de campo, estudos de caso e relato de experiência apresentando resultados de pesquisas inéditas; c) artigos de reflexão ou análises críticas: posição dos autores sobre a ética/bioética na fisioterapia, associado ou não à revisão de literatura.

Os artigos originais foram apresentados quanto ao objetivo primário e principais resultados. E quanto à abordagem do estudo, utilizou-se a seguinte categorização: a) teoria ética e/ou bioética na fisioterapia: abordagem de conceitos éticos, morais e de justiça; b) ética profissional: análise de atitudes éticas, como tomada de decisão, 
responsabilidade e conflitos éticos; c) ética no cuidado: análise do fisioterapeuta como cuidador; d) código de ética: análise do código de ética profissional ou atitudes profissionais de acordo com o código; e) pesquisa e Fisioterapia: importância da ética em pesquisa na Fisioterapia ${ }^{14}$.

\section{Resultados}

Identificaram-se inicialmente 155 publicações. Após a análise dos títulos, excluíram-se 108 artigos: 7 indexados em mais de uma base de dados; 9 repetidos; 24 indisponíveis; 27 relacionaram a fisioterapia clínica e 49 os títulos não relacionavam a fisioterapia à ética e/ou bioética. Após a aplicação dos critérios de inclusão e exclusão, 33 artigos foram selecionados para leitura e análise dos resumos. Nessa fase, excluíram-se 12 que não atendiam aos critérios de inclusão. Após a análise dos artigos completos, excluíram-se 4 publicações, sendo selecionados 23 artigos.

Os artigos foram publicados em periódicos de seis países, com maior concentração de textos do Brasil (11) e Estados Unidos (5) e Austrália (3). Reino Unido, África do Sul, Suécia e Canadá contribuíram com um artigo cada. A Revista Physical Therapy teve o maior número de publicações (6). As outras tiveram a frequência de um a três artigos cada uma. Os anos de 2010 e 2011 apresentaram o maior número de publicações, 6 (seis $-26,08 \%$ ) cada um. A Tabela 1 apresenta os dados gerais dos artigos.

Quanto ao tipo de estudo, houve predominância de artigos originais (12) sobre ética, bioética, atitudes morais, código de ética da Fisioterapia e cuidar em fisioterapia. Encontraram-se quatro revisões sistemáticas e seis artigos de reflexão e/ou análise crítica (Tabela 1).

Quanto à categorização dos estudos, observou-se que alguns artigos abordaram mais de um tema. Predominou a fundamentação e exploração de teorias e conceitos éticos utilizados na fisioterapia (4), sua correlação com a prática profissional (5) ou com o código de ética (1). Cinco artigos analisaram a importância da pesquisa na fisioterapia (Tabela 1). A tabela abaixo apresenta os achados dos artigos originais (Tabela 2).

Em 2004 e 2005 não encontraram-se publicações que abordassem o tema deste estudo. Em 2006 e 2007, foram encontrados quatro artigos que abordaram temas diferenciados. O mais relevante foi o de Linda Scheirton e cols que refletiu sobre 
negligências durante $\mathrm{o}$ tratamento fisioterapêutico. Apontaram a pequena quantidade de estudos sobre esse tema e indicam a necessidade de priorizar estratégias para promover a segurança do paciente durante a terapia para evitar negligências. Esses eventos afetam moralmente o fisioterapeuta envolvido ${ }^{18}$.

Em 2008 e 2009, foram identificados dois artigos, sendo um deles uma revisão sistemática. Pesquisas sobre bioética e fisioterapia estão em crescimento no âmbito mundial representando fator importante para o fortalecimento da identidade profissional ${ }^{14}$. A outra publicação focalizou a preocupação sobre irregularidades éticas em relação à divulgação de serviços e publicidade profissional ${ }^{19}$.

Em 2010 e 2011 houve aumento significativo dos temas deste estudo. As abordagens foram mais diversificadas, incluindo preocupação com conhecimentos e atitudes éticas e/ou bioéticas dos profissionais, pesquisa, análise do código de ética e autonomia profissional.

Não houve publicação em 2012. E em 2013 observou-se a retomada da preocupação na abordagem da autonomia profissional. Figueiredo, Gratão e Martins destacaram que a análise da autonomia apenas sob a ótica do Código de Ética profissional foge dos textos bioéticos que valorizam a autonomia do paciente ${ }^{10}$. Lorenzo e Bueno ${ }^{13}$ reiteram que o princípio da autonomia se caracteriza pela busca do equilíbrio entre direitos dos pacientes em favor das suas escolhas e obrigações do fisioterapeuta em respeitá-las ${ }^{13}$.

\section{Discussão}

Os anos de 2010, 2011 e 2013 foram os mais importantes para o crescimento das reflexões éticas e bioéticas na fisioterapia. Diante dos inúmeros conflitos éticos vivenciados pelo fisioterapeuta, acredita-se que o número de publicações ainda é pequeno $(n=17)$ e baseia-se em abordagens predominantemente filosóficas. A fisioterapia carece de estudos sobre a bioética na prática profissional ${ }^{12,14,15,17,24}$.

O aumento das publicações no Brasil relaciona-se à implantação das Diretrizes Curriculares Nacionais das profissões da saúde que preconiza a inclusão da Bioética nas matrizes curriculares, à difusão dos princípios bioéticos pela consolidação do Sistema Brasileiro de Revisão Ética das Pesquisas (CEP/CONEP), à introdução da disciplina Bioética em programas de pós-graduação, e à criação de programas de pósgraduação em Bioética em São Paulo e Brasília33. 
Há escassez de pesquisas sobre o raciocínio moral empregado na prática profissional e no processo de tomada de decisão, elemento essencial para o cumprimento de obrigações éticas e legais ${ }^{22,24}$. Delany e colaboradores ${ }^{12}$ argumentam $^{2}$ que o fisioterapeuta é um agente moral. A tomada de decisões éticas e clínicas requer a ponderação nas relações com os pacientes, outros membros da equipe de saúde, instituições e políticas de saúde.

A importância do vínculo entre ética, bioética e fisioterapia exige maior discussão e reflexão. Especialistas em bioética que abordem questões específicas da fisioterapia e de fisioterapeutas contribuirá para melhor compreensão dos problemas éticos que emergem da prática clínica. É importante apresentar novos argumentos e concepções pela divulgação de relatos de experiências da prática cotidiana. As publicações poderiam ser incluídas em periódicos específicos de bioética e da fisioterapia, que deveriam estar mais sensíveis à divulgação desses temas ${ }^{11}$. As revistas precisam criar normas claras, consistentes e adequadas para proteção ética dos autores e participantes dos estudos ${ }^{17}$.

Dois artigos tomaram como referência o código de ética enfatizando a importância de seu conhecimento. O código define obrigações, deveres e delimita comportamentos a serem adotados, indicando os princípios morais em que estão fundamentados. A apropriação dessas informações contribui para eticidade das ações. Porém, código tem limites significativos quando o assunto é o processo de tomada de decisão na presença dos conflitos éticos ${ }^{24,26}$. Esta lacuna pode ser preenchida se o fisioterapeuta adotar e aplicar conhecimentos bioéticos no contexto do cuidar em saúde suprindo, assim, as necessidades de cada paciente ${ }^{12,16,20,24}$.

$O$ artigo de revisão de Lorenzo e Bueno ${ }^{13}$ não encontrou estudos que analisassem problemas envolvendo a autonomia do paciente ocasionados por limites legais ou da capacidade física para decidir. Mas, houve relatos de influência sobre sua voluntariedade provocadas por situações de vulnerabilidade social: baixo nível de instrução, dificuldades de acesso a bens e serviços de saúde, condições de submissão social ou diversidade etnocultural. Os autores não notaram distinção clara entre proteção à vulnerabilidade e paternalismo.

Observou-se aceitação frequente de que a bioética e/ou a ética devem fazer parte da formação dos fisioterapeutas. A dimensão ética nos cuidados em saúde e na prática profissional é imensurável. Conhecimentos éticos e bioéticos favorecem a 
obtenção de habilidades para atuar nos conflitos éticos que surgem no cotidiano clínico, analisar criticamente as situações e tomar decisões consistentes ${ }^{34,35}$.

\section{Conclusão}

Os resultados apontaram para número reduzido de publicações sobre o vínculo ética, bioética e fisioterapia, comparando-se ao volume de publicações existentes na área da saúde. Pode-se considerar que as reflexões sobre estes temas não estão acompanhando as necessidades da sociedade e da profissão, tornando-se necessário superar essa carência de publicações e relatos de vivências clínicas.

Observou-se que os autores se preocupam com a preparação ética, bioética e moral do fisioterapeuta para o enfrentamento dos conflitos vivenciados no cotidiano da profissão. As reflexões apontaram para a necessidade de se criar linhas de pesquisa na interseção entre ética e/ou bioética, fisioterapia e autonomia profissional. Vivências clínicas e questões de caráter ético são comuns entre fisioterapeutas e a possibilidade de divulgar esses fatos pode ajudar no preparo de outros profissionais objetivando atuação mais responsável e humanizada.

\section{Referências}

1. Marques WL. Ética no trabalho. 1a ed. Paraná: Gráfica Vera Cruz; 2010.

2. Novaes MRCG, Guilhem D, Novaes LCG, Lolas F. Diagnóstico de la inserción de la ética en la carrera de medicina en Brasil. Educ méd. 2010;13(4):239-46.

3. Kipper DJ. Ética teoria e prática: uma visão multidisciplinar. 1a ed. Porto alegre: Edipucrs; 2006.

4. Machado D, Carvalho M, Machado B, Pacheco F. A formação ética do fisioterapeuta. Fisioter Mov. 2007;20(3):101-5.

5. Lolas F. Bioética: o que é, como se faz. 2a ed. São Paulo: Edições Loyola; 2005.

6. Badaró AFV. Ética e bioética na práxis da Fisioterapia: Desvelando comportamentos [tese]. Brasília (DF): Universidade de Brasília, 2008.

7. Mellado SR. Universidades Y Docencia en Bioética. 1a ed. Alicante: Editorial Clube Universitario; 2004.

8. Rebelatto JR, Botomé SP. Fisioterapia no Brasil: fundamentos para uma ação preventiva e perspectivas profissionais. 2a ed. São Paulo: Manole; 2011. 
9. Praestegaard J, Gard G. The perceptions of Danish physiotherapists on the ethical issues related to the physiotherapist-patient relationship during the first session: phenomenological approach. BMC Medical Ethics. 2011;12(21):1-11.

10. Figueiredo LC, Gratão ACM, Martins EF. Código de ética para fisioterapeutas e terapeutas ocupacionais revela conteúdos relacionados à autonomia profissional. Fisioter Pesq. 2013;20(4):394-400.

11. Poulis I. Bioethics and physiotherapy. J Med Ethics. 2007(8);33:435-6.

12. Delany CM, Edwards I, Jensen GM, Skinner E. Closing the Gap Between Ethics Knowledge and Practice Through Active Engagement: An Applied Model of Physical Therapy Ethics. Phys Ther. 2010;90(7):1068-78.

13. Lorenzo CFG, Bueno GTA. A interface entre bioética e fisioterapia nos artigos brasileiros indexados. Fisioter Mov. 2013;26(4):763-75.

14. Badaró AFV, Guilhem D. Bioética e pesquisa na Fisioterapia: aproximação e vínculos. Fisioter e Pesq. 2008;15(4):402-7.

15. Hossne WS, Zaher VL. Bioética e reabilitação. O mundo da saúde, São Paulo. 2006;30(1):11-9.

16. Greenfield $\mathrm{BH}$. The meaning of caring in five expericenced physical therapists. Physiother Theory and Pract. 2006;22(4):175-87.

17. Henley LD, Frank DM. Reporting ethical protections in Physical Therapy Research. Phys Ther. 2006;86(4):499-509.

18. Scheirton LS, Um K, Lohman H, Cochran TM. Error and patient safety: Ethical analysis of cases occupational and physical therapy practice. Med Health Care Philos. 2007;10(10):301-11.

19. Schnaider J, Pereira Júnior AA, Lima WC. Publicidade e ética na fisioterapia. Fisioter Bras. 2009;10(2):139-143.

20. Greenfiel B, Jensen GM. Beyond a Code of Ethics for every day. Physiother Res Int. 2010(2);15:88-95.

21. Townsend A, Cox SM, Li LC. Qualitative Research Ethics: Enhancing evidencebased practice in physical therapy. Phys Ther. 2010;90(4)615-28.

22. Carpenter $\mathrm{C}$. Moral distress in physical therapy practice. Physiother Theory Pract. 2010;26(2):69-78.

23. Swisher LL. Moral Reasoning among physical therapists: Results of the defining issues test. Physiother Res Int. 2010;15(2):69-79. 
24. Swisher LL, Hiller P. The revised APTA Code of Ethics for the physical therapist and Standards of Ethical Conduct for the Physical Therapist Assistant: Theory, Purpose, Process, and Significance. Phys Ther. 2010;90(5):803-24.

25. Martini A. Reabilitação, ética e técnica. Ciênc. Saúde Coletiva. 2011;16(4):22639.

26. Edwards I, Delany CM, Townsend AF, Swisher LL. Moral agency as enacted justice: a clinical and ethical decision-making framework for responding to health inquities and social injustice. Phys Ther. 2011;91(11):1653-63.

27. Edwards I, Delany CM, Townsend AF, Swisher LL. New perspectives on the theory of Justice: Implications for physical therapy ethics and clinical practice. Phys Ther. $2011 ; 91(11): 1642-52$.

28. Silva ID, Silveira MFA. A humanização e a formação do professional em fisioterapia. Ciênc. Saúde Coletiva. 2011;16(Supl.1):1535-46.

29. Badaró AFV, Guilhem D. Perfil sociodemográfico e profissional de fisioterapeutas e origem das suas concepções sobre ética. Fisioter Mov. 2011;24(3):445-54.

30. Santuzzi CH, Scardua MJ, Reetz JB, Firme KS, Lira NO, Gonçalves WLS. Aspectos éticos e humanizados da fisioterapia na UTI: uma revisão sistemática. Fisioter Mov. 2013;26(2):415-22.

31. Masson IFB, Baldan CS, Ramalho VR, Junior IE, Masson DF, Peixoto BO, et al. Conhecimento e envolvimento de graduandos em fisioterapia acerca dos preceitos éticos da experimentação animal. Rev bioét. 2013;21(1):136-41.

32. Versiani AHV, Martimbianco AC, Peccin MS. Mapping of the evidence from systematic reviews of the Cochrane Collaboration for decision-making within physiotherapy. Sao Paulo Med J. 2013;131(1):39-45.

33. Haddad AE, Pierantoni CR, Ristoff D, Xavier IM, Giolo J, Silva LB. A trajetória dos cursos de graduação na Saúde: 1991-2004. 15 v. Brasília: Instituto Nacional de Estudos e Pesquisas Educacionais Anísio Teixeira, 2006.

34. Couceiro-Vidal A. Enseñanza de la bioética y planes de estudios basados en competencias. Educ méd. 2008;11(2):69-76.

35. Trota RA. Experiencias metodológicas ante el reto de la enseñanza de la ética. Educ méd. 2006;9(1):49-50. 
Tabela 1 - Artigos segundo ano, autor principal, título, tipo de estudo e categorização, 2004 a novembro de 2014.

\begin{tabular}{|c|c|c|c|c|}
\hline Ano & Autoria & Título & Estudo & Categoria \\
\hline 2006 & Hossne WS $\mathrm{W}^{15}$ & Bioética e reabilitação & Revisão & $\begin{array}{c}\text { Teoria ética e } \\
\text { bioética }\end{array}$ \\
\hline 2006 & $\begin{array}{c}\text { Greenfiel } \\
\mathrm{BH}^{16}\end{array}$ & The meaning of caring in five expericenced physical therapists & Original & Ética no cuidado \\
\hline 2006 & Henley LD ${ }^{17}$ & Reporting ethical protections in Physical Therapy Research & Original & $\begin{array}{l}\text { Pesquisa e } \\
\text { Fisioterapia }\end{array}$ \\
\hline 2007 & Scheirton $\mathrm{L}^{18}$ & $\begin{array}{l}\text { Error and patient safety: Ethical analysis of cases occupational and } \\
\text { physical therapy practice }\end{array}$ & Original & $\begin{array}{c}\text { Teoria ética/ética } \\
\text { profissional/ética no } \\
\text { cuidado }\end{array}$ \\
\hline 2008 & Badaró AFV ${ }^{14}$ & Bioética e pesquisa na Fisioterapia: aproximação e vínculos & Revisão & $\begin{array}{l}\text { Pesquisa e } \\
\text { fisioterapia }\end{array}$ \\
\hline 2009 & $\begin{array}{l}\text { Schnaider } \\
\text { JS }^{19}\end{array}$ & Publicidade e ética na fisioterapia & Reflexão & Código de ética \\
\hline 2010 & Greenfield B20 & Beyond a Code of Ethics for every day & Reflexão & $\begin{array}{l}\text { Teoria ética/código } \\
\text { de ética }\end{array}$ \\
\hline 2010 & $\begin{array}{l}\text { Delany } \\
\text { ESCM }^{12}\end{array}$ & $\begin{array}{l}\text { Closing the Gap Between Ethics Knowledge and Practice Through } \\
\text { Active Engagement: An Applied Model of Physical Therapy Ethics }\end{array}$ & Original & $\begin{array}{l}\text { Teoria ética/ética } \\
\text { profissional }\end{array}$ \\
\hline
\end{tabular}




\begin{tabular}{|c|c|c|c|c|}
\hline 2010 & Townsend $A^{21}$ & $\begin{array}{l}\text { Qualitative Research Ethics: Enhancing evidence-based practice in } \\
\text { physical therapy }\end{array}$ & Original & $\begin{array}{l}\text { Pesquisa e } \\
\text { fisioterapia }\end{array}$ \\
\hline 2010 & Carpenter $\mathrm{C}^{22}$ & Moral distress in physical therapy practice & Reflexão & $\begin{array}{c}\text { Teoria ética/ética } \\
\text { profissional }\end{array}$ \\
\hline 2010 & Swisher LL ${ }^{23}$ & $\begin{array}{l}\text { Moral Reasoning among physical therapists: Results of the defining } \\
\text { issues test }\end{array}$ & Original & Teoria ética \\
\hline 2011 & Martini $A^{25}$ & Reabilitação, ética e técnica & Reflexão & Teoria ética \\
\hline 2011 & Edward $I^{26}$ & $\begin{array}{l}\text { Moral agency as enacted justice: a clinical and ethical decision-making } \\
\text { framework for responding to health inequities and social injustice }\end{array}$ & Reflexão & Teoria ética \\
\hline 2011 & $\begin{array}{l}\text { Praestegaard } \\
\mathrm{J}^{9}\end{array}$ & $\begin{array}{l}\text { The perceptions of Danish physiotherapists on the ethical issues related } \\
\text { to the physiotherapist-patient relationship during the first session: } \\
\text { phenomenological approach }\end{array}$ & Original & $\begin{array}{c}\text { Teoria ética/ética } \\
\text { profissional }\end{array}$ \\
\hline 2011 & Silva ID ${ }^{28}$ & A humanização e a formação do professional em fisioterapia & Original & Ética no cuidado \\
\hline 2011 & Badaró AFV 29 & $\begin{array}{l}\text { Perfil sociodemográfico e profissional de fisioterapeutas e origem das } \\
\text { suas concepções sobre ética }\end{array}$ & Original & Ética profissional \\
\hline
\end{tabular}




\begin{tabular}{|c|c|c|c|c|}
\hline 2013 & $\begin{array}{l}\text { Lorenzo } \\
\text { CFG }^{13}\end{array}$ & A interface entre bioética e fisioterapia nos artigos brasileiros indexados & Revisão & $\begin{array}{l}\text { Pesquisa e } \\
\text { Fisioterapia }\end{array}$ \\
\hline 2013 & Santuzzi $\mathrm{CH}^{30}$ & $\begin{array}{l}\text { Aspectos éticos e humanizados da fisioterapia na UTI: uma revisão } \\
\text { sistemática }\end{array}$ & Revisão & $\begin{array}{c}\text { Ética } \\
\text { profissional/ética no } \\
\text { cuidado }\end{array}$ \\
\hline 2013 & $\begin{array}{l}\text { Figueiredo } \\
\qquad \text { LC }^{10}\end{array}$ & $\begin{array}{l}\text { Código de ética para fisioterapeutas e terapeutas ocupacionais revela } \\
\text { conteúdos relacionados à autonomia profissional }\end{array}$ & Original & Código de ética \\
\hline 2013 & Masson IFB ${ }^{31}$ & $\begin{array}{l}\text { Conhecimento e envolvimento de graduandos em fisioterapia acerca } \\
\text { dos preceitos éticos da experimentação animal }\end{array}$ & Original & $\begin{array}{l}\text { Pesquisa e } \\
\text { Fisioterapia }\end{array}$ \\
\hline 2013 & $\begin{array}{l}\text { Versiani } \\
\mathrm{AHV}^{32}\end{array}$ & $\begin{array}{l}\text { Mapping of the evidence from systematic reviews of the Cochrane } \\
\text { Collaboration for decision-making within physiotherapy }\end{array}$ & Revisão & Ética profissional \\
\hline
\end{tabular}

Tabela 2 - Artigos originais, objetivos e resultados

\begin{tabular}{|c|c|c|}
\hline Autor & Objetivo & Resultados \\
\hline \multicolumn{3}{|l|}{ Principal } \\
\hline $\begin{array}{l}\text { Greenfiel, } \\
\qquad \mathrm{BH}^{16}\end{array}$ & $\begin{array}{l}\text { Descrever o cuidar na prática clínica de } \\
\text { cinco fisioterapeutas experientes }\end{array}$ & $\begin{array}{l}\text { Quatro relataram que cuidar constitui uma prática da ética ou } \\
\text { orientação moral. Há dificuldade de cuidar em ambiente de atenção } \\
\text { gerenciada, onde o sistema valoriza o controle de custos e lucro }\end{array}$ \\
\hline Henley LD' & $\begin{array}{l}\text { Examinar com que frequência os artigos } \\
\text { em revistas de fisioterapia relatam sobre } \\
\text { proteções éticas básicas }\end{array}$ & $\begin{array}{l}806 \text { artigos: } 48 \% \text { documentavam a aprovação do Comitê de Ética e } \\
\text { consentimento informado. Artigos sobre intervenções clínicas tiveram } \\
\text { a maior taxa (64\%). Artigos com métodos qualitativos e relatos de }\end{array}$ \\
\hline
\end{tabular}


casos apresentaram os menores índices. 26\% garantiram

confidencialidade

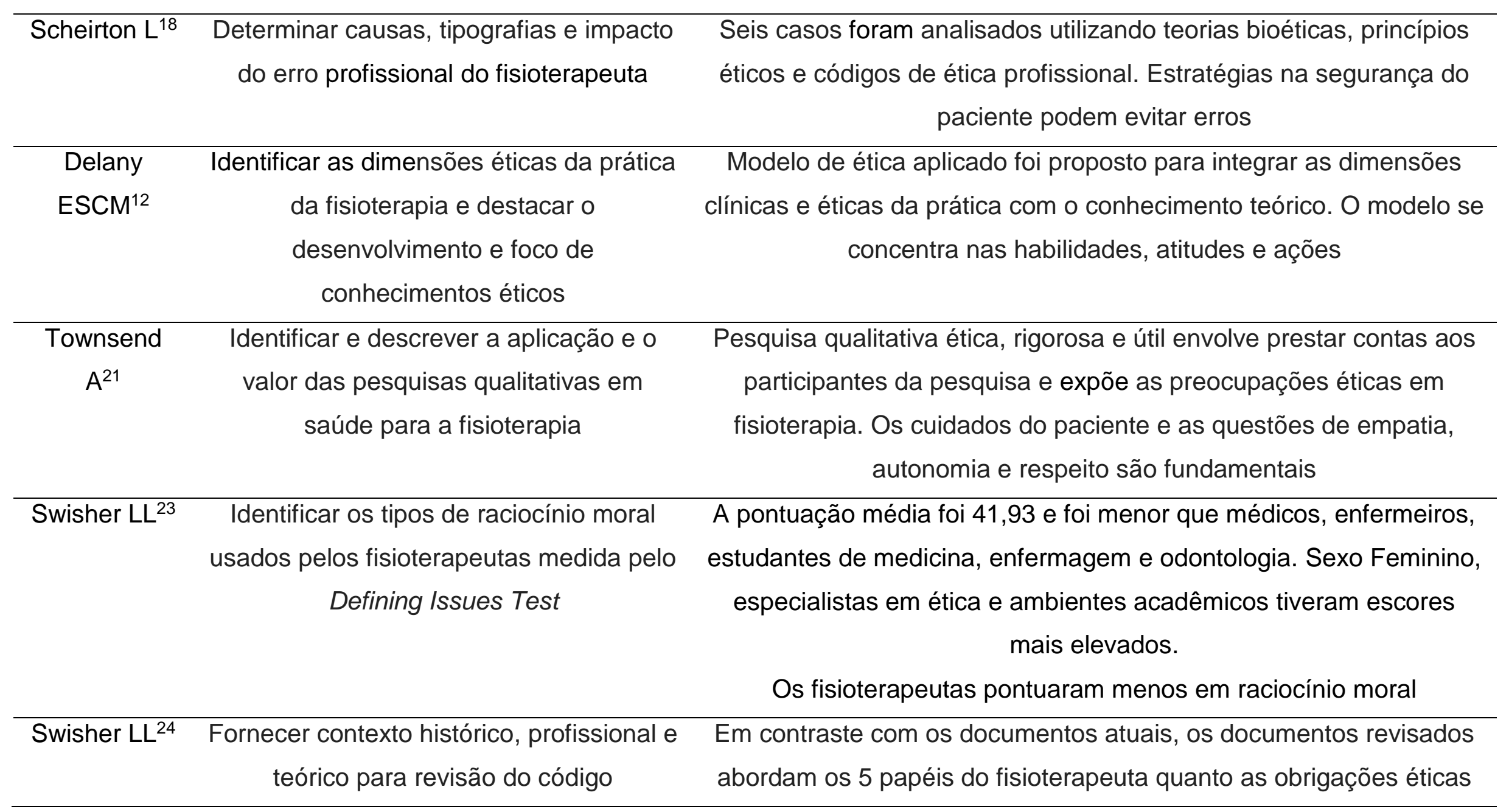




\begin{tabular}{|c|c|c|}
\hline $\begin{array}{c}\text { Praestegaard } \\
\mathrm{J}^{9}\end{array}$ & $\begin{array}{l}\text { Analisar se as questões éticas durante a } \\
\text { primeira sessão de fisioterapia são } \\
\text { discutidas na prática privada }\end{array}$ & $\begin{array}{l}\text { A primeira sessão e o contexto clínico (influência do ambiente } \\
\text { clínico) em consultório particular são essenciais do ponto de vista } \\
\text { ético }\end{array}$ \\
\hline Masson IFB ${ }^{31}$ & $\begin{array}{l}\text { Analisar universitários de fisioterapia } \\
\text { sobre o uso de animais na pesquisa e no } \\
\text { ensino e o nível de conhecimento e } \\
\text { interesse sobre o tema }\end{array}$ & $\begin{array}{l}193 \text { alunos: maioria conhecia sobre ética animal, mas nunca } \\
\text { participaram de aulas práticas com animais e afirmam nunca ter } \\
\text { pensado sobre substituir animais por métodos alternativos. Se } \\
\text { sensibilizaram quanto ao número de animais utilizados e } \\
\text { demonstraram conhecimento e respeito }\end{array}$ \\
\hline
\end{tabular}




\section{Resultados da pesquisa relacionada às Instituições de Ensino}

Esta parte do estudo está em acordo aos objetivos específicos desta tese em apresentar o panorama de inserção curricular das disciplinas de ética e ou deontologia e bioética nos cursos de fisioterapia das Universidades e Centros Universitários no Brasil; descrever o perfil das disciplinas de bioética ministradas no curso de fisioterapia pelas Universidades e Centros Universitários no Brasil mediante análise das ementas e identificação das linhas teóricas e temáticas predominantes nessas abordagens; identificar se os docentes que ministram as disciplinas de ética e ou deontologia e bioética no curso de fisioterapia apresentam trajetória acadêmica com os temas em questão; e analisar o referencial bibliográfico utilizado para ministrar as disciplinas de ética e ou deontologia e bioética para o curso de fisioterapia. 


\subsection{Caracterização da Amostra}

A amostra deste estudo foi composta por 234 Instituições de Ensino Superior que ofereciam o curso de fisioterapia, sendo destas 145 Universidades e 89 Centros Universitários.

De acordo com a Região, no site do e-MEC a região Sudeste apresentou o maior número de Universidades e Centros Universitários que ofertavam o curso de fisioterapia ( $n=120 ; 51,28 \%$ ), seguindo pela região Sul com 48 Instituições $(20,51 \%)$. Demais dados estão representados na Tabela 1 abaixo.

Tabela 1 - Número por região de Universidades e Centros Universitários no Brasil que ofertam o curso de fisioterapia.

\begin{tabular}{c|c|c} 
REGIÃO & N & Porcentagem \\
\hline Norte & 13 & 5,56 \\
\hline Nordeste & 34 & 14,53 \\
\hline Centro-Oeste & 19 & 8,12 \\
\hline Sudeste & 120 & 51,28 \\
\hline Sul & 48 & 20,51 \\
\hline Total & 234 & 100,00 \\
\hline
\end{tabular}

Fonte: Ministério da Educação e Cultura (http://emec.mec.gov.br/).

O Estado de São Paulo foi o que apresentou o maior número de Instituições que ofertam o curso de fisioterapia ( $n=66 ; 28,21 \%)$, seguida por Minas Gerais ( $n=29$; 12,39\%). Os Estados do Acre e Roraima não apresentaram nenhuma Universidade ou Centro Universitário com o curso conforme Tabela 2. 
Tabela 2 - Número por Estado de Universidades e Centros Universitários no Brasil que ofertam o curso de fisioterapia.

\begin{tabular}{|c|c|c|}
\hline ESTADO & $n$ & Porcentagem \\
\hline Alagoas & 1 & 0,43 \\
\hline Amapá & 1 & 0,43 \\
\hline Amazonas & 5 & 2,14 \\
\hline Bahia & 8 & 3,42 \\
\hline Ceará & 4 & 1,71 \\
\hline Distrito Federal & 6 & 2,56 \\
\hline Espírito Santo & 4 & 1,71 \\
\hline Goiás & 7 & 2,99 \\
\hline Maranhão & 1 & 0,43 \\
\hline Mato Grosso & 2 & 0,85 \\
\hline Mato Grosso do Sul & 4 & 1,71 \\
\hline Minas Gerais & 29 & 12,39 \\
\hline Pará & 4 & 1,71 \\
\hline Paraíba & 3 & 1,28 \\
\hline Paraná & 14 & 5,98 \\
\hline Pernambuco & 8 & 3,42 \\
\hline Piauí & 3 & 1,28 \\
\hline Rio de Janeiro & 21 & 8,97 \\
\hline Rio Grande do Norte & 3 & 1,28 \\
\hline Rio Grande do Sul & 21 & 8,97 \\
\hline Rondônia & 1 & 0,43 \\
\hline
\end{tabular}




\begin{tabular}{c|c|c}
\hline Santa Catarina & 13 & 5,56 \\
\hline São Paulo & 66 & 28,21 \\
\hline Sergipe & 3 & 1,28 \\
\hline Tocantins & 2 & 0,85 \\
\hline Total & 234 & 100,00 \\
\hline
\end{tabular}

Fonte: Ministério da Educação e Cultura (http://emec.mec.gov.br/).

Após os critérios de inclusão e exclusão, foram excluídas 111 Instituições (47,43\%), sendo que: 47 universidades $(20,08 \%)$ e 26 centros universitários $(11,11 \%)$ não apresentavam todos os dados necessários para o desenvolvimento e análise deste estudo; 24 instituições (10,25\%) por apresentarem mais de uma filial no Brasil com a mesma matriz curricular; $11(4,7 \%)$ onde apesar do site do e-MEC identificar o curso de fisioterapia, as instituições não o ofertavam; 2 (0,85\%) foram descredenciadas pelo MEC e somente uma $(0,42 \%)$ o site estava indisponível.

Foram incluídas então neste estudo 123 Instituições (52,56\%) que apresentavam o curso de fisioterapia no Brasil, onde 77 eram Universidades (62,60\%) e 46 Centros Universitários (37,40\%).

Quanto a natureza jurídica, houve predomínio de Instituições Privadas ( $n=93$; $75,61 \%$ ) seguidas por Públicas Federais ( $n=19 ; 15,45 \%$ ) conforme Tabela 3 abaixo.

Tabela 3 - Natureza Jurídica da Universidades e Centros Universitários no Brasil que ofertam o curso de fisioterapia.

\begin{tabular}{c|c|c}
\hline NATUREZA JURIDICA & Frequência & Porcentagem \\
\hline Pública Federal & 19 & 15,45 \\
\hline Pública Estadual & 9 & 7,32 \\
\hline Privada & 93 & 75,61 \\
\hline Pública Municipal & 2 & 1,63 \\
\hline Total & 123 & 100,00 \\
\hline
\end{tabular}

Fonte: Ministério da Educação e Cultura (http://emec.mec.gov.br/). 
A média da carga horária do curso de fisioterapia das 123 Universidades e Centros Universitários analisados neste estudo foi de 4235,94 variando de 3230 a 5980 horas/aulas $(\mathrm{DP}=371,39)$ e mediana de 4060. Somente 3 instituições apresentaram a carga horária inferior a 4000 horas/aulas (2,44\%).

Quanto ao número de períodos, encontrou-se que em a grande maioria dos cursos de fisioterapia estão sendo ofertados em 10 períodos $(n=88 ; 71,54 \%)$ conforme Tabela 4.

Tabela 4 - Total de períodos dos cursos de fisioterapia das Universidades e Centros Universitários no Brasil.

\begin{tabular}{c|c|c}
\hline PERIODOS DO CURSO & Frequência & Porcentagem \\
\hline $\mathbf{8}$ & 21 & 17,07 \\
\hline $\mathbf{9}$ & 14 & 11,38 \\
\hline $\mathbf{1 0}$ & 88 & 71,54 \\
\hline Total & 123 & 100,00 \\
\hline
\end{tabular}

Fonte: Sites das Universidades e Centros Universitários selecionados para o estudo.

\subsection{A disciplina de Bioética}

Após a análise curricular, pode-se observar que 106 instituições (86,18\%) não apresentavam a disciplina de bioética sem estar vinculada a outra disciplina na matriz do curso de fisioterapia.

A carga horária da disciplina de bioética variou de 30 a 80 horas/aulas (DP=13,67), com média de 39,64 e mediana de 40 horas/aula. Diante disso, pôde-se observar que 14 instituições apresentaram a disciplina com carga horária variando entre 30 a 40 horas/aulas.

Quanto ao semestre que a disciplina de bioética é ministrada, obteve-se resultados variados. $O$ semestre que mais coincidiu entre as instituições foi o quarto ( $n=7 ; 41,18 \%)$, seguido do segundo período com $5(29,41 \%)$ (Tabela 5$)$. 
Tabela 5 - Semestre da disciplina de bioética.

\begin{tabular}{c|c|c}
\hline SEMESTRE & Frequência & Porcentagem \\
\hline $\mathbf{1}$ & 2 & 11,76 \\
\hline $\mathbf{2}$ & 5 & 29,41 \\
\hline $\mathbf{4}$ & 1 & 5,88 \\
\hline $\mathbf{6}$ & 7 & 41,18 \\
\hline $\mathbf{8}$ & 1 & 5,88 \\
\hline Total & 1 & 5,88 \\
\hline Font: Sites das Universidades e cen & 17 & 100,00 \\
\hline
\end{tabular}

Fonte: Sites das Universidades e Centros Universitários selecionados para o estudo.

E das 17 Instituições que apresentavam a disciplina (13,82\%), somente 6 apresentavam informações sobre o plano de ensino. Destas, 5 tinham disponível em domínio público a ementa, 4 apresentaram os objetivos da disciplina, 4 obteve-se 0 conteúdo programático e 5 foi possível obter as referências bibliográficas utilizadas para ministrar o conteúdo didático. Segue abaixo as ementas com a classificação das abordagens da bioética na Tabela 6 e os objetivos na tabela 7 . 
Tabela 6 - Ementas da disciplina de bioética com a classificação das abordagens bioéticas seguindo o proposto por Costa e Diniz (2001) ${ }^{61}$.

\begin{tabular}{|c|c|c|}
\hline $\begin{array}{l}\text { Instituição de Ensino } \\
\text { Superior }\end{array}$ & Ementa & $\begin{array}{c}\text { Classificação } \\
\text { (Costa e Diniz, 2001) }\end{array}$ \\
\hline $\begin{array}{l}\text { Universidade Federal do } \\
\text { Piauí }\end{array}$ & $\begin{array}{l}\text { Noções sobre Ética, moral } \\
\text { e Direito. Biotecnologias } \\
\text { Tradicionais e Atuais. } \\
\text { Nascimento e História da } \\
\text { Bioética. Os modelos } \\
\text { explicativos da Bioética. } \\
\text { Estudos de Caso. } \\
\text { Genética e Bioética. } \\
\text { Bioética e Biodireito. }\end{array}$ & Filosófica e Temática \\
\hline $\begin{array}{l}\text { Universidade Estadual de } \\
\text { Ciências da Saúde de } \\
\text { Alagoas }\end{array}$ & $\begin{array}{l}\text { Compreender } 0 \\
\text { significado da Bioética, } \\
\text { bem como a refletir sobre } \\
\text { relações entre profissional } \\
\text { de saúde e paciente. }\end{array}$ & Temática \\
\hline $\begin{array}{ll}\text { Universidade } & \text { de } \\
\text { Blumenau } & \end{array}$ & $\begin{array}{l}\text { Estudos sistemáticos da } \\
\text { conduta humana na área } \\
\text { das Ciências da Vida e da } \\
\text { Saúde, examinada à luz } \\
\text { dos valores e princípios da } \\
\text { autonomia, beneficência, } \\
\text { não maleficência e justiça. }\end{array}$ & Histórica \\
\hline $\begin{array}{l}\text { Universidade Federal do } \\
\text { Pampa }\end{array}$ & $\begin{array}{l}\text { Esta disciplina tem por } \\
\text { finalidade estudar a } \\
\text { bioética inserida na } \\
\text { prática. Aborda os } \\
\text { fundamentos da bioética e } \\
\text { objetiva a reflexão sobre } \\
\text { temas como respeito à } \\
\text { pessoa, privacidade e }\end{array}$ & Temática \\
\hline
\end{tabular}




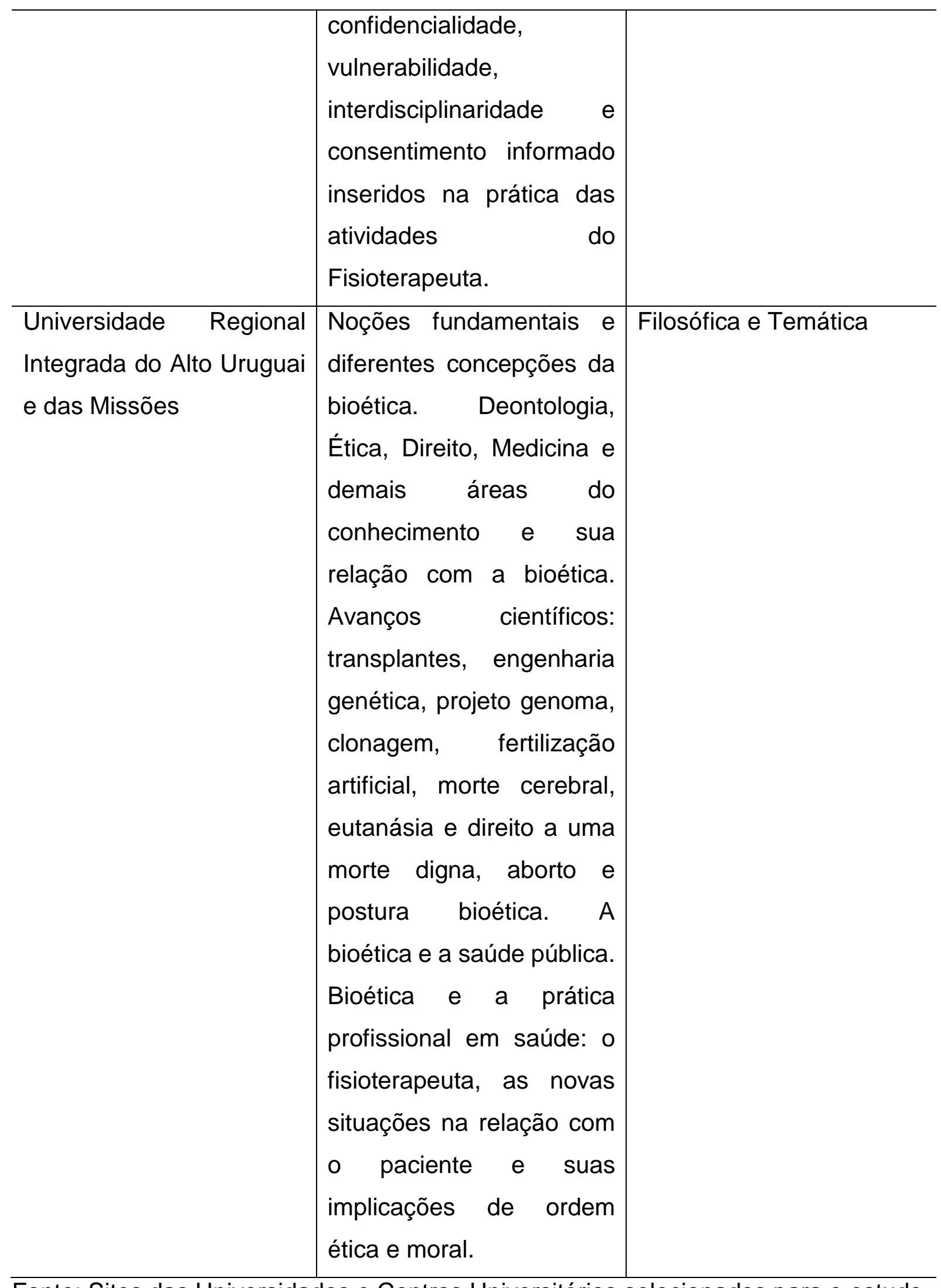

Fonte: Sites das Universidades e Centros Universitários selecionados para o estudo.

A abordagem historicista é restrita a uma universidade. Nenhuma universidade abordou os três temas no seu ementário. Pode-se observar que há maior preocupação 
em abordar a temática, não incluindo casos e questões conflituosas do ponto de vista ético, princípios e fundamentos filosóficos da bioética para auxiliar o fisioterapeuta, através de correntes teóricas, a refletir e lidar com os conflitos bioéticos a serem enfrentados na prática profissional.

Tabela 7 - Objetivos da disciplina de bioética.

Instituição

Universidade Estadual de Ciências da Definir e conceituar a bioética, discutir Saúde de Alagoas

Universidade de Blumenau

Universidade de Blumenau

Universidade Federal de Santa Maria principais aspectos atinentes à vida, à saúde, e à morte, bem como a relação do profissional e paciente.

Capacitar o aluno para a compreensão e para uma intervenção qualificada dos grupos multiprofissionais nas organizações da Saúde.

Conhecer ética e bioética,
contextualizado no atual modelo de saúde vigente no país, estimulando uma reflexão das intervenções do profissional de saúde e seus aspectos éticos, propiciando uma consciência crítica pautada nos preceitos éticos e bioéticos.

Universidade Regional Integrada do Alto Uruguai e das Missões Analisar as complexas questões éticas, bioéticas e jurídicas que surgem em decorrência dos avanços tecnológicos e científicos de forma interdisciplinar e abrangente; aprofundar os estudos relativos ao direito à vida, à existência, à dignidade da pessoa humana e à liberdade das pesquisas científicas. 
Referente ao conteúdo programático abordado nas 4 instituições que o apresentavam no plano de ensino da disciplina, observa-se que há maior preocupação das instituições em abordar as temáticas referentes a bioética e as pesquisas em seres humanos e animais. É restrito então conforme observado na Tabela 8 abaixo, abordagens que envolvem a história da bioética e reflexões filosóficas importantes para lidar com os conflitos bioéticos enfrentados no dia a dia do profissional fisioterapeuta.

Tabela 8 - Conteúdo programático da disciplina de bioética.

\section{Instituição \\ Conteúdo Programático}

Universidade Estadual de Pesquisa em seres humanos e animais; Normas

Ciências da Saúde de Alagoas

para pesquisas em seres humanos e animais;

Conceito de morte encefálica; A Genética

Humana e a Bioética; Normas Brasileiras sobre

OGM; Reprodução Humana; Doação e

transplante de órgão; Aborto.

Universidade Federal do Pampa Introdução à Bioética: Histórico; Conceituação;

Fundamentos de Bioética: Respeito à pessoa;

Privacidade e Confidencialidade;

Vulnerabilidade; Interdisciplinaridade;

Consentimento Informado; Bioética Clínica:

Comitês de Bioética; Métodos de discussão de casos em Bioética Clínica.

Universidade Federal de Santa Introdução à Bioética: Fundamentação Maria antropológica da bioética; Antecedentes históricos, principais correntes; Conceitos fundamentais em Bioética: ética, moral e direito; Modelos explicativos em bioética: principialismo, autonomia, paternalismo, beneficência, não maleficência; Bioética e Informação: Tipos de Informação e suas características; Privacidade; Confidencialidade; Ética em Pesquisa: Pesquisa com seres humanos: Resolução 196/96; 


\begin{tabular}{l|l}
\hline Universidade Regional Integrada & $\begin{array}{l}\text { Pesquisa com animais; Comitê de ética em } \\
\text { pesquisa com seres humanos; Comitês e } \\
\text { Comissões: Comitê de ética hospitalar; Comitê }\end{array}$ \\
\hline de bioética; Comitê de biossegurança; Comitê \\
de pesquisa em animais.
\end{tabular}

Fonte: Sites das Universidades e Centros Universitários selecionados para o estudo.

Além da categorização seguindo Costa e Diniz (2001) ${ }^{61}$, observou-se que os temas trabalhados com maior ênfase e detalhes nas ementas e conteúdos programáticos são os relacionados às práticas biomédicos e ou biotecnológicas geralmente associadas aos seres humanos (aborto, clonagem, morte, eutanásia, genética, experimentações, entre outros). Contudo, conflitos éticos envolvendo questões como relação profissional-profissional e profissional-paciente apresenta 
grande restrição. Tal fato é observado na Tabela 7 onde em nenhum momento o objetivo da disciplina foi voltado para tal fato.

Quanto as referências bibliográficas utilizadas (Tabela 9) na disciplina de bioética, pôde-se observar que não existe um padrão adotado pela maior parte das Instituições. Foi possível identificar somente 2 obras em comum entre duas Instituições, porém pode-se considerar muito antigas. Cita-se então Fundamentos de Bioética de Christian de Paul Barchifontaine e Léo Pessini de 1996, 2002 e 2004; e Bioética de Marco Segre e Cláudio Cohen de 1995, 1999, 2002 e 2008. O autor Ricardo Timm de Souza foi citado duas vezes dentro do mesmo referencial teórico com duas obras diferentes: Ética como fundamento: Uma introdução à ética contemporânea e Ciência e Ética: os grandes desafios.

Tabela 9 - Referências da disciplina de bioética.

\begin{tabular}{|c|c|}
\hline Instituição & Referências \\
\hline $\begin{array}{l}\text { Universidade Federal do } \\
\text { Piauí }\end{array}$ & $\begin{array}{l}\text { BARCHIFONTAINE, Christian de Paul \& PESSINI, } \\
\text { Léo. Fundamentos de Bioética. Editora Paulus, São } \\
\text { Paulo 1996; Biotecnologia e Bioética: Para onde } \\
\text { vamos? Editora Vozes. Rio de Janeiro, 2004; } \\
\text { SAUWEN, R.F. O Direito "in vitro": da Bioética ao } \\
\text { Biodireito". 2. ed. Lúmen Júris Rio Janeiro: 2000; } \\
\text { CONTI, Matilde Carone Slaibi. Biodireito - A norma da } \\
\text { vida. Editora Forense. Rio de Janeiro, 2004; } \\
\text { BARCHIFONTAINE, Christian de Paul \& PESSINI, } \\
\text { Léo. Problemas Atuais de Bioética. 6a Edição. } \\
\text { Edições Loyola. Livro Texto, São Paulo 2002; } \\
\text { GARRAFA, Volnei e COSTA, Sérgio Ibiapina. A } \\
\text { Bioética no Século XXI. Editora Universidade de } \\
\text { Brasília. Brasília, 2000; Grande Temas da Atualidade: } \\
\text { Bioética e Biodireito. Aspectos Jurídicos e } \\
\text { Metajurídicos. Editora Forense. Rio de Janeiro 2004. }\end{array}$ \\
\hline $\begin{array}{l}\text { Universidade Estadual de } \\
\text { Ciências Da Saúde de } \\
\text { Alagoas }\end{array}$ & $\begin{array}{l}\text { OLIVEIRA, Fátima. Engenharia genética moderna. 4a } \\
\text { ed. São Paulo, 1996, 135p; SEGRE, Marco \& } \\
\text { COHEN, Cláudio (Org.). Bioética. São Paulo. Edusp, }\end{array}$ \\
\hline
\end{tabular}




\begin{tabular}{|c|c|}
\hline & $\begin{array}{l}\text { 1995. 173p; VARGA, Andrew C. Problemas de } \\
\text { bioética. UNISINOS, 300P. }\end{array}$ \\
\hline $\begin{array}{l}\text { Universidade } \text { Federal do } \\
\text { Pampa }\end{array}$ & $\begin{array}{l}\text { ANJOS, Márcio Fabri; SIQUEIRA, José Eduardo } \\
\text { (Orgs.). Bioética no Brasil: Tendências e perspectivas. } \\
\text { São Paulo, SP: Sociedade Brasileira de Bioética, } \\
\text { 2007; LOLAS, Fernando. Bioética - o que é, como se } \\
\text { faz. São Paulo: Loyola, 2005; FORTES, Paulo Antonio } \\
\text { de Carvalho. Ética e saúde: questões éticas, } \\
\text { deontológicas e legais: autonomia e direitos do } \\
\text { paciente: estudo de casos. São Paulo: EPU, 2005; } \\
\text { TIMM DE SOUZA, Ricardo. Ética como fundamento: } \\
\text { Uma introdução à ética contemporânea. São } \\
\text { Leopoldo: Nova Harmonia, 2004; COSTA, Judith } \\
\text { Martins; MÖLLER, Letícia Ludwig (Orgs.). Bioética e } \\
\text { Responsabilidade. Rio de Janeiro: Cia. Editora } \\
\text { Forense, 2009; TIMM DE SOUZA, Ricardo (Org.). } \\
\text { Ciência e Ética: Os grandes desafios. Porto Alegre: } \\
\text { Edipucrs, 2005. }\end{array}$ \\
\hline $\begin{array}{l}\text { Universidade Federal de } \\
\text { Santa Maria }\end{array}$ & $\begin{array}{l}\text { BELLINO, Francesco. Fundamentos da Bioética: } \\
\text { Aspectos antropológicos, ontológicos e morais. } \\
\text { Bauru: EDUSC, 1997; BOFF, Leonardo. Saber cuidar } \\
\text { - Ética do humano- Compaixão pela terra. Petrópolis, } \\
\text { RJ. Ed. Vozes, 1999; CADERNOS DE ÉTICA EM } \\
\text { PESQUISA: Conselho Federal de Medicina: } \\
\text { http://www.cfm.org.br/ Revista Bioética; CONEP } \\
\text { (Comissão Nacional de ética em Pesquisa) - } \\
\text { http:conselho.saúde.gov.Br; DEMO, Pedro. } \\
\text { Conhecimento Moderno: sobre ética e intervenção do } \\
\text { conhecimento. Petrópolis, RJ: Vozes, 1997. parte I, p. } \\
\text { 15-82; DINIZ, Débora; GUILHEM, Dirce. O que é } \\
\text { Bioética. São Paulo. Ed. Brasiliense, 2002. (Coleção } \\
\text { Primeiros Passos). }\end{array}$ \\
\hline
\end{tabular}




\begin{tabular}{|c|c|}
\hline $\begin{array}{l}\text { Universidade Regional } \\
\text { Integrada do Alto Uruguai e } \\
\text { das Missões }\end{array}$ & $\begin{array}{l}\text { BARCHIFONTAINE, Christian de Paul de. Bioética e } \\
\text { início da vida: alguns desafios. São Paulo: Idéias \& } \\
\text { Letras, 2004; NAMBA, Edison Tetsuzo. Manual de } \\
\text { bioética e biodireito. São Paulo: Atlas, 2009; SEGRE, } \\
\text { Marco; COHEN, Claudio (Org.). Bioética. São Paulo: } \\
\text { Edusp, 1999, 2002, 2008; ENGELHARDT, JR, } \\
\text { H.Tristram. Fundamentos da Bioética. Tradução: José } \\
\text { A. Ceschin. São Paulo: Loyola, 1998, 2004, } 2011 . \\
\text { Título original: The Foundations of Bioethics; KRELL, } \\
\text { Olga Jubert Gouveia. Reprodução humana assistida } \\
\text { e filiação civil: princípios éticos e jurídicos. Curitiba: } \\
\text { Juruá, 2006, 2009; LEITE, Eduardo de Oliveira } \\
\text { (Coord.). Grandes temas da atualidade: bioética e } \\
\text { biodireito. Rio de Janeiro: Forense, 2004; SARLET, } \\
\text { Ingo Wolfgang. Dignidade da Pessoa Humana e } \\
\text { Direitos Fundamentais na Constituição Federal de } \\
\text { 1988. Porto Alegre: Livraria do Advogado, 2001; } \\
\text { SARTORI, Giana Lisa Zanardo. Direito e Bioética: o } \\
\text { desafio da interdisciplinaridade. Erechim: EDIFAPES, } \\
\text { 2001. }\end{array}$ \\
\hline
\end{tabular}

Fonte: Sites das Universidades e Centros Universitários selecionados para o estudo.

Pôde-se observar também que o referencial bibliográfico utilizado para o ensino da bioética nas instituições não são totalmente específicos desta disciplina. Há referências que abordam a Ética, a Deontologia, o Direito, o Biodireito e a Comissão Nacional de Ética em pesquisa, além de se observar livros produzidos há mais de 10 anos, porém de referências.

Quanto à titulação do professor que ministra a disciplina de Bioética, somente uma instituição a apresentou (mestre). Após uma busca na plataforma lattes (http://www.cnqp.br) pela trajetória acadêmica do professor com a área Bioética, podese observar que o mesmo realizou um curso de aperfeiçoamento em Bioética aplicada no ano de 2013, porém a sua área de atuação e a linha de pesquisa não estavam ligadas aos temas relacionados a este tema. 


\subsection{A disciplina de Ética e ou Deontologia}

A disciplina de ética e ou deontologia apareceu com maior frequência nas matrizes curriculares dos cursos de fisioterapia das 123 instituições analisadas, dessa forma, 62 instituições $(50,41 \%)$ apresentaram a disciplina com maior frequência no segundo $(n=10 ; 16,13 \%)$, terceiro $(n=11 ; 17,74 \%)$ e quarto semestres $(n=10 ; 16,13 \%)$. A carga horária média da disciplina foi de 41,03 horas/aulas ( $D P=12,79$ ), variando de 28,33 a 90 horas/aula, com mediana de 40 horas/aula (Tabela 10).

Tabela 10 - Semestre ao qual a disciplina de ética e ou deontologia é ministrada.

\begin{tabular}{c|c|c}
\hline $\begin{array}{c}\text { SEMESTRE DE } \\
\text { ÉTICA/DEONTOLOGIA }\end{array}$ & Frequência & Porcentagem \\
\hline $\mathbf{1}$ & 1 & 1,61 \\
\hline $\mathbf{2}$ & 10 & 16,13 \\
\hline $\mathbf{3}$ & 11 & 17,74 \\
\hline $\mathbf{4}$ & 10 & 16,13 \\
\hline $\mathbf{5}$ & 6 & 9,68 \\
\hline $\mathbf{6}$ & 7 & 11,29 \\
\hline $\mathbf{7}$ & 8 & 12,90 \\
\hline $\mathbf{8}$ & 6 & 1,61 \\
\hline $\mathbf{9}$ & 1 & 3,23 \\
\hline $\mathbf{1 0}$ & 2 & 100,00 \\
\hline Total & 62 & 108 \\
\hline
\end{tabular}

$\overline{\text { Fonte: Sites das Universidades e Centros Universitários selecionados para o estudo. }}$

E das 62 Instituições que apresentavam a disciplina, somente 23 apresentavam informações sobre o plano de ensino. Segue abaixo o nome das Universidades ou Centros Universitários, o nome da disciplina e as ementas na Tabela 11. 
Tabela 11 - Relação das Instituições que apresentam a disciplina de ética e ou deontologia e a ementa.

\begin{tabular}{|c|c|c|}
\hline Instituição & $\begin{array}{l}\text { Nome da } \\
\text { Disciplina }\end{array}$ & Ementa \\
\hline $\begin{array}{l}\text { Universidade } \\
\text { Federal do } \\
\text { Piauí }\end{array}$ & $\begin{array}{c}\text { Ética e } \\
\text { deontologia }\end{array}$ & 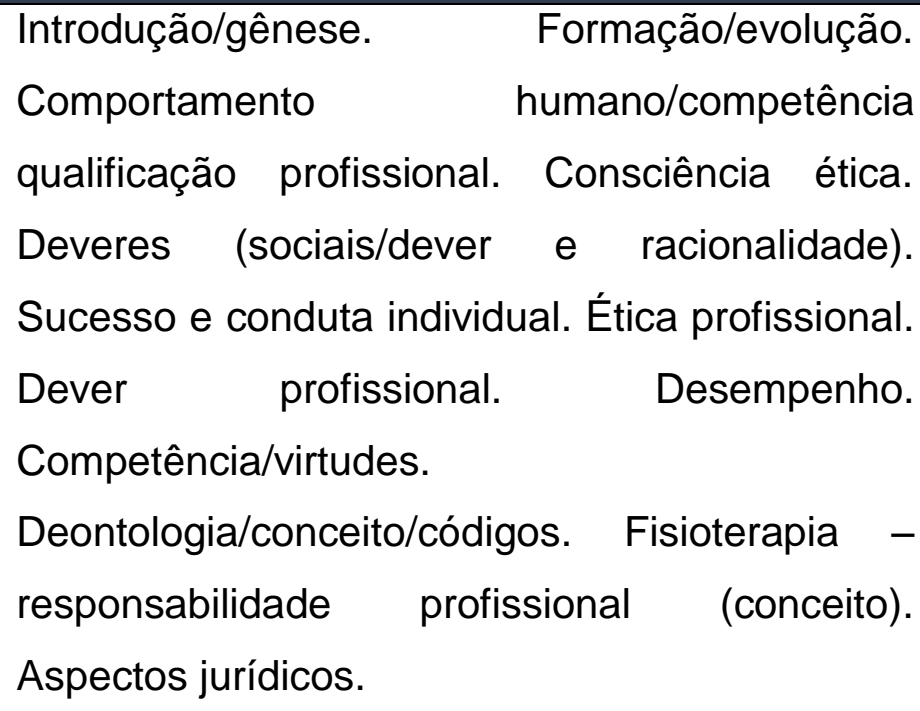 \\
\hline $\begin{array}{c}\text { Universidade } \\
\text { Potiguar }\end{array}$ & $\begin{array}{c}\text { Ética e } \\
\text { profissionalismo }\end{array}$ & $\begin{array}{l}\text { Principais concepções de ética, bioética e } \\
\text { cidadania na fisioterapia como marco regulatório } \\
\text { e seus desdobramentos no exercício } \\
\text { profissional. A responsabilidade com os serviços } \\
\text { de saúde, mudanças legais e a concepção da } \\
\text { profissão como prática social. A relação da } \\
\text { fisioterapia e suas entidades de classe. }\end{array}$ \\
\hline $\begin{array}{l}\text { Universidade } \\
\text { Federal do } \\
\text { Pernambuco }\end{array}$ & $\begin{array}{c}\text { Ética e } \\
\text { deontologia }\end{array}$ & $\begin{array}{l}\text { Propiciar fundamentação teórica e filosófica, } \\
\text { procura habilitar o estudante para interpretar e } \\
\text { refletir sobre o código de ética profissional. } \\
\text { Objetiva, ainda, capacitar o aluno para } \\
\text { desempenhar a profissão escolhida com } \\
\text { consciência de suas funções e responsabilidade } \\
\text { junto ao paciente, aos seus colegas e outros } \\
\text { profissionais, bem como a comunidade e } \\
\text { especialmente a sua classe profissional. }\end{array}$ \\
\hline $\begin{array}{l}\text { Universidade } \\
\text { Estadual de } \\
\text { Ciências da }\end{array}$ & $\begin{array}{c}\text { Ética e } \\
\text { Deontologia }\end{array}$ & $\begin{array}{l}\text { A disciplina visa fornecer aos alunos } \\
\text { conhecimentos básicos para refletir questões } \\
\text { relativas à moral, à ética e à deontologia, bem }\end{array}$ \\
\hline
\end{tabular}




\begin{tabular}{|c|c|c|}
\hline $\begin{array}{l}\text { Saúde de } \\
\text { Alagoas }\end{array}$ & & $\begin{array}{l}\text { como a influência destas matérias no exercício } \\
\text { profissional da fisioterapia perante a sociedade, } \\
\text { frente às políticas sociais e de saúde. }\end{array}$ \\
\hline $\begin{array}{l}\text { Universidade } \\
\text { Federal do } \\
\text { Sergipe }\end{array}$ & $\begin{array}{l}\text { Ética, } \\
\text { Deontologia e } \\
\text { Cidadania }\end{array}$ & $\begin{array}{l}\text { Conceitos, contexto e princípios éticos, legais, } \\
\text { morais e filosóficos da profissão de fisioterapeuta } \\
\text { e na pesquisa em saúde. Estudo da teoria } \\
\text { organizacional na ética. Evolução do } \\
\text { pensamento ético atual. Aspectos } \\
\text { comportamentais do profissional e a ética } \\
\text { moderna. Os aspectos jurídicos e legais para o } \\
\text { cumprimento da ética na fisioterapia. }\end{array}$ \\
\hline $\begin{array}{l}\text { Universidade } \\
\text { do Estado da } \\
\text { Bahia }\end{array}$ & Ética & $\begin{array}{l}\text { Estuda e discute a ética do ponto de vista do } \\
\text { indivíduo e da sociedade com ênfase na bioética. }\end{array}$ \\
\hline $\begin{array}{l}\text { Universidade } \\
\text { Paraense }\end{array}$ & $\begin{array}{c}\text { Ética } \\
\text { profissional }\end{array}$ & $\begin{array}{l}\text { Noções básicas de administração. Organização } \\
\text { e estruturação de serviços de fisioterapia. } \\
\text { Legislação e regulamentação do profissional } \\
\text { fisioterapeuta. Órgãos de classe: papel, objetivos } \\
\text { e funcionamento. Aspectos éticos da prática } \\
\text { profissional. }\end{array}$ \\
\hline $\begin{array}{l}\text { Universidade } \\
\text { Alto Vale do } \\
\text { Rio do Peixe }\end{array}$ & $\begin{array}{c}\text { Ética e } \\
\text { Deontologia }\end{array}$ & $\begin{array}{l}\text { Introdução e conceituação de ética, bem como } \\
\text { seus posicionamentos filosóficos; direito, moral e } \\
\text { religião. Finalidade da fisioterapia e papel } \\
\text { profissional do fisioterapeuta; relacionamento } \\
\text { com o doente, a comunidade, colegas e outros } \\
\text { profissionais da saúde. Apresentação das } \\
\text { normas disciplinadoras do exercício profissional, } \\
\text { as limitações e o orientador profissional do } \\
\text { fisioterapeuta, remuneração profissional. } \\
\text { (Código de ética profissional do fisioterapeuta) } \\
\text { considera ainda, os conselhos federais e } \\
\text { regionais de fisioterapia e sua vinculação a } \\
\text { terapia ocupacional (principais leis e resoluções }\end{array}$ \\
\hline
\end{tabular}




\begin{tabular}{|c|c|c|}
\hline & & $\begin{array}{l}\text { da profissão). Bioética: origem e } \\
\text { desenvolvimento da bioética e saúde pública. } \\
\text { Bioética clínica: bioética e educação da área da } \\
\text { saúde. Aspectos éticos da reprodução humana. } \\
\text { Manutenção da vida. Charlatanismo e } \\
\text { curandeirismo. Ciência e ética. Pesquisas } \\
\text { biomédicas em seres humanos. Fisioterapia } \\
\text { legal: conceituação e princípios. Noções de } \\
\text { direito. Documentos fisioterapêuticos: aspectos } \\
\text { éticos e legais. latrogenia. Responsabilidade civil } \\
\text { e penal do fisioterapeuta frente à imperícia, a } \\
\text { imprudência e a negligência. Relação do } \\
\text { fisioterapeuta com as instituições de saúde. } \\
\text { Sigilo profissional. }\end{array}$ \\
\hline $\begin{array}{c}\text { Universidade } \\
\text { do } \\
\text { Contestado - } \\
\text { UNC }\end{array}$ & $\begin{array}{c}\text { Ética e } \\
\text { deontologia }\end{array}$ & $\begin{array}{l}\text { Introdução e conceituação de ética, bem como } \\
\text { seus posicionamentos filosóficos; direito, moral e } \\
\text { religião. Finalidade da fisioterapia e papel } \\
\text { profissional do fisioterapeuta; relacionamento } \\
\text { com o doente, a comunidade, colegas e outros } \\
\text { profissionais da saúde. Apresentação das } \\
\text { normas disciplinadoras do exercício profissional, } \\
\text { as limitações e o orientador profissional do } \\
\text { fisioterapeuta, remuneração profissional. } \\
\text { (Código de ética profissional do fisioterapeuta) } \\
\text { considera ainda, os conselhos federais e } \\
\text { regionais de fisioterapia e sua vinculação a } \\
\text { terapia ocupacional (principais leis e resoluções } \\
\text { da profissão). Bioética: origem e } \\
\text { desenvolvimento da bioética e saúde pública. } \\
\text { Bioética clínica: bioética e educação da área da } \\
\text { saúde. Aspectos éticos da reprodução humana. } \\
\text { Manutenção da vida. Charlatanismo e } \\
\text { curandeirismo. Ciência e ética. Pesquisas }\end{array}$ \\
\hline
\end{tabular}




\begin{tabular}{|c|c|c|}
\hline & & $\begin{array}{l}\text { biomédicas em seres humanos. Fisioterapia } \\
\text { legal: conceituação e princípios. Noções de } \\
\text { direito. Documentos fisioterapêuticos: aspectos } \\
\text { éticos e legais. latrogenia. Responsabilidade civil } \\
\text { e penal do fisioterapeuta frente à imperícia, a } \\
\text { imprudência e a negligência. Relação do } \\
\text { fisioterapeuta com as instituições de saúde. } \\
\text { Sigilo profissional. }\end{array}$ \\
\hline $\begin{array}{l}\text { Universidade } \\
\text { do Planalto } \\
\text { Catarinense - } \\
\text { Uniplac }\end{array}$ & $\begin{array}{c}\text { Ética e } \\
\text { Deontologia }\end{array}$ & $\begin{array}{l}\text { Introdução e conceituação de ética. Direito, } \\
\text { moral e religião. Papel da fisioterapia. } \\
\text { Relacionamento com o doente, a comunidade, } \\
\text { colegas e outros profissionais da saúde. } \\
\text { Apresentação das normas disciplinares do } \\
\text { exercício profissional, as limitações, código de } \\
\text { ética profissional do fisioterapeuta. Bioética. } \\
\text { Aspectos éticos da reprodução humana. } \\
\text { Manutenção da vida. Ciência e ética. Pesquisas } \\
\text { biomédicas em seres humanos. } \\
\text { Responsabilidade civil e penal do fisioterapeuta. } \\
\text { Sigilo profissional. }\end{array}$ \\
\hline $\begin{array}{c}\text { Universidade } \\
\text { do Vale do } \\
\text { Itajaí }\end{array}$ & Deontologia & $\begin{array}{l}\text { Dever profissional. Linhas básicas da conduta } \\
\text { profissional. Ética profissional. Exigências } \\
\text { básicas do profissional. Leis e atos normativos } \\
\text { da profissão do fisioterapeuta. }\end{array}$ \\
\hline $\begin{array}{l}\text { Universidade } \\
\text { de Blumenau }\end{array}$ & $\begin{array}{c}\text { Ética e } \\
\text { deontologia }\end{array}$ & $\begin{array}{l}\text { Fundamentação filosófica sobre ética e } \\
\text { deontologia. Estudo e análise da legislação da } \\
\text { profissão e suas implicações. Reflexão das } \\
\text { discussões éticas nos aspectos morais e } \\
\text { deontológicos. Perfil profissional. Postura } \\
\text { profissional perante a comunidade e demais } \\
\text { profissionais da área da saúde. Autarquias. }\end{array}$ \\
\hline $\begin{array}{l}\text { Universidade } \\
\text { Feevale }\end{array}$ & Ética & $\begin{array}{l}\text { Estuda a dimensão do ético na vida a partir das } \\
\text { diferentes relações pessoais, profissionais e }\end{array}$ \\
\hline
\end{tabular}




\begin{tabular}{|c|c|c|}
\hline & & $\begin{array}{l}\text { sociais que os seres estabelecem consigo, com } \\
\text { o outro e com o universo. }\end{array}$ \\
\hline $\begin{array}{l}\text { Universidade } \\
\text { Regional } \\
\text { Integrada do } \\
\text { Alto Uruguai } \\
\text { e das } \\
\text { Missões }\end{array}$ & $\begin{array}{c}\text { Ética } \\
\text { profissional }\end{array}$ & $\begin{array}{l}\text { Leis e atos normativos da profissão do } \\
\text { fisioterapeuta. Competências dos conselhos } \\
\text { regionais e federal. Código de ética. Decreto de } \\
\text { lei e resoluções. Coeficiente honorário do } \\
\text { fisioterapeuta. Convênios e assistências. }\end{array}$ \\
\hline PUC Minas & $\begin{array}{c}\text { Ética e } \\
\text { deontologia }\end{array}$ & $\begin{array}{l}\text { Conceituação de ética e deontologia. O código } \\
\text { de ética profissional, a contemporaneidade e a } \\
\text { saúde. As dimensões pessoais, técnica e social } \\
\text { da responsabilidade profissional. }\end{array}$ \\
\hline $\begin{array}{l}\text { Universidade } \\
\text { Federal de } \\
\text { Juiz de Fora }\end{array}$ & $\begin{array}{c}\text { Ética e } \\
\text { deontologia }\end{array}$ & $\begin{array}{l}\text { Conceito de ética, moral, deontologia e bioética. } \\
\text { Ato moral e responsabilidade profissional. O } \\
\text { fisioterapeuta e a bioética. O fisioterapeuta e } \\
\text { outros profissionais de saúde. Legislação vigente } \\
\text { e código de ética profissional de fisioterapia e } \\
\text { terapia ocupacional. }\end{array}$ \\
\hline $\begin{array}{l}\text { Universidade } \\
\text { Federal de } \\
\text { Minas Gerais }\end{array}$ & $\begin{array}{c}\text { Ética e } \\
\text { deontologia }\end{array}$ & $\begin{array}{l}\text { Ética e deontologia da legislação sobre as } \\
\text { profissões de fisioterapia e terapia ocupacional } \\
\text { no brasil: conceitos e objetivos. Órgãos de } \\
\text { classe: papel, objetivos e funcionamento. } \\
\text { Aspectos éticos da prática profissional. }\end{array}$ \\
\hline $\begin{array}{c}\text { Universidade } \\
\text { Severino } \\
\text { Sombra }\end{array}$ & $\begin{array}{c}\text { Ética e } \\
\text { deontologia }\end{array}$ & $\begin{array}{l}\text { Relações entre ética, moral, educação e } \\
\text { cidadania; valores éticos fundamentais. Bioética: } \\
\text { princípios fundamentais. Código de deontologia } \\
\text { da fisioterapia. Relações profissionais e } \\
\text { humanização na atuação do fisioterapeuta. }\end{array}$ \\
\hline $\begin{array}{c}\text { PUC } \\
\text { Campinas }\end{array}$ & $\begin{array}{c}\text { Ética e } \\
\text { deontologia em } \\
\text { fisioterapia }\end{array}$ & $\begin{array}{l}\text { Compreensão dos valores e das relações entre } \\
\text { ética e moral, levando ao entendimento e } \\
\text { discussão dos modelos éticos que possibilitem a } \\
\text { fundamentação teórica da ética profissional. }\end{array}$ \\
\hline
\end{tabular}




\begin{tabular}{c|c|l}
\hline Unimar & $\begin{array}{c}\text { Ética e } \\
\text { deontologia }\end{array}$ & $\begin{array}{l}\text { A disciplina aborda textos de enfoque na ética } \\
\text { pessoal, social, política e profissional, pois estas } \\
\text { abordagens motivam melhor as discussões em } \\
\text { sala. As aulas direcionarão lógicas de raciocínio } \\
\text { para as questões polêmicas sobre bioética, } \\
\text { comportamentos sociais, e humanização. O } \\
\text { código de ética da fisioterapia será apresentado } \\
\text { em grupos, onde os alunos terão livre escolha de } \\
\text { dramatização na abordagem. }\end{array}$ \\
\hline Francisco & profissional & $\begin{array}{l}\text { Princípios e fundamentos da moral e dos } \\
\text { deveres. Aspectos éticos. Estudo da legislação } \\
\text { constitucional e processual da fisioterapia. } \\
\text { Código de ética profissional. Bioética. }\end{array}$ \\
\hline Unirg & Ética e & $\begin{array}{l}\text { Conceitos básicos. Postura ética profissional, } \\
\text { acadêmica e social. Estudo e análise dos } \\
\text { princípios legais da profissão (código de ética). } \\
\text { Reflexões éticas, bioéticas e morais da profissão } \\
\text { nos aspectos científico, social, comunitário e de }\end{array}$ \\
\hline inter-relacionamento de classes.
\end{tabular}

Fonte: Sites das Universidades e Centros Universitários selecionados para o estudo.

O ementário da ética para os acadêmicos de fisioterapia conforme a Tabela 11 acima é voltado, classicamente, para conceitos básicos e para a deontologia. Há também uma variedade de temas estudados dentro da disciplina. Nota-se que a bioética também é apontada em oito ementas de diferentes instituições. $E$ duas Instituições apresentaram a mesma ementa.

Dentre as instituições listadas, quatro apresentaram o conteúdo programático da disciplina de ética e ou deontologia e onze as referências bibliográficas, conforme descrito nas tabelas 12 e 13 . 
Tabela 12 - Descrição das instituições e o conteúdo programático abordado nas disciplinas de ética e ou deontologia.

\section{Instituição}

Universidade

Estadual De

Ciências Da

Saúde De Alagoas

Universidade

Federal De Santa

Maria

\section{Conteúdo Programático}

Introdução sobre Ética e Estudo de Caso Objeto da Ética + apresentação e discussão dos temas dos artigos Caráter Histórico da Moral Virtudes e Deveres Conceito de Deontologia Estudo de caso: fisioterapia, ética e moral Sistema COFFITO-CREFITO Código de Ética Franquia Profissional $x$ Inscrição Definitiva Fisioterapia e Sigilo Profissional Referencial de honorários - RNHF Eutanásia e Distanásia Inscrição de Consultório e clínica.

UNIDADE 1 - A FORMAÇÃO DO PROFISSIONAL EM
FISIOTERAPIA: A Legislação da Profissão; História da Fisioterapia no Brasil; Leis e Atos Normativos da Profissão do Fisioterapeuta; O Curso de Fisioterapia; Diretrizes Curriculares dos Cursos de Graduação em Fisioterapia; Diretrizes Curriculares Nacionais do Curso de Graduação em Fisioterapia; Cursos de Fisioterapia no Brasil; O Curso de Fisioterapia na UFSM; Áreas de Atuação Profissional; Atribuições Profissionais; Especialidades da Fisioterapia; Realidade e Perspectiva de atuação profissional; Campo de atuação do Fisioterapeuta; Perfil profissional; Relação terapeuta/paciente; Equipes de saúde e inter-áreas: multidisciplinariedade, interdisciplinaridade e interdisciplinaridade; O Fisioterapeuta como profissional da Saúde; Saúde e SUS; A Fisioterapia e o SUS; UNIDADE 2 DEONTOLOGIA EM FISIOTERAPIA: Tipos de informação e suas características; Privacidade; Confidencialidade; UNIDADE 3 - DESENVOLVIMENTO DA ATITUDE CIENTÍFICA NAS AÇÕES DO FISIOTERAPEUTA: O Método Científico e sua importância; Princípios Científicocomportamentais na ação do Fisioterapeuta. 


\begin{tabular}{|c|c|}
\hline $\begin{array}{c}\text { Universidade } \\
\text { Regional Integrada }\end{array}$ & $\begin{array}{l}\text { Noções gerais: Ética, Bioética, Autonomia, Moral; Conselhos } \\
\text { Regionais e Federal; Atribuições dos Delegados e Delegacias }\end{array}$ \\
\hline $\begin{array}{l}\text { Do Alto Uruguai E } \\
\text { Das Missões }\end{array}$ & $\begin{array}{l}\text { Regionais; Legislação do Profissional Fisioterapeuta; } \\
\text { Documentos Fisioterapêuticos: Aspectos Éticos e Legais; } \\
\text { Código de Ética Profissional da Fisioterapia; } \\
\text { Responsabilidade Civil e Penal do Fisioterapeuta frente à } \\
\text { imperícia, imprudência e negligência; Documentos emitidos } \\
\text { pelo profissional Fisioterapeuta: Laudos, Pareceres, } \\
\text { Atestados e Perícias; Referencial de Honorários } \\
\text { Fisioterapêuticos; Normatização da jornada de trabalho; } \\
\text { Funcionamento dos Diferentes Convênios; Relação do } \\
\text { Profissional Fisioterapeuta com as Instituições de Saúde: } \\
\text { Clínicas; Hospitais; Instituições Privadas, Públicas e } \\
\text { Filantrópicas; Ética em trabalho em equipe; Relação } \\
\text { Fisioterapeuta x Paciente, nos diversos campos de atuação; } \\
\text { Segredo Profissional, Valor Social da Profissão. }\end{array}$ \\
\hline Unimar & $\begin{array}{l}\text { Introdução à ética geral - Tipos de abordagem ética para o } \\
\text { meio, influências culturais - Ética social, política, conjugal, } \\
\text { familiar e profissional - Direitos do Paciente e Bioética - Código } \\
\text { de ética da Fisioterapia }\end{array}$ \\
\hline
\end{tabular}

Fonte: Sites das Universidades e Centros Universitários selecionados para o estudo.

Quanto ao conteúdo programático das quatro instituições que o apresentaram, observa-se que o conteúdo é voltado especificamente ao estudo da deontologia do profissional fisioterapeuta. 
Tabela 13 - Descrição das instituições e as referências bibliográficas das disciplinas de ética e ou deontologia.

Instituição

Universidade

Federal Do Piaui

\section{Referências}

CARVALHO, L. C. de. A Ética dos Profissionais de Saúde. São Paulo: Forense. FORTES, P. A. Ética e saúde: questões deontológicas e legais, autonomias e direitos do paciente estudo de caso. São Paulo: EPU, 1998. VAZQUEZ, Adolfo Sanchez. Ética. Rio de Janeiro: Civilização Brasileira, 2003. ANGERAMI - LAMON, V. A. A Ética na Saúde. São Paulo: Pioneira, 2002. GAUDERER, E Christian. Os direitos do paciente: um manual de sobrevivência. Rio de Janeiro: Record, 1991. SÁ, Antônio Lopes de. Ética Profissional. São Paulo: Atlas, 2000. SINGER, P. Ética prática. São Paulo: Martins Fontes, 1994. VALLS, Álvaro L.M. O que é ética. São Paulo: Brasiliense, 2000.
Universidade Potiguar

CHAUI, Marilena. Convite à filosofia. 8. ed. São Paulo: Ática, 1997. SUNG, Jung Mo. Conversando sobre ética e sociedade. 8. ed. Petrópolis: Vozes, 2000. WEISCHEDEL, Wilhelm. A escada dos fundos da Filosofia. São Paulo: Angra, 2004.

BIBLIOGRAFIA COMPLEMENTAR

GALLO, S. (coord) Ética e cidadania: caminhos da filosofia. 8. ed. São Paulo: Papirus, 2006. SALDANHA, Nelson. Ética e história. Rio de Janeiro: Renovar, 1998.

Universidade

Estadual De Ciências Da Saúde De Alagoas
BIBLIOGRAFIA BÁSICA: BOFF, Leonardo. O despertar da águia. $12^{\mathrm{a}}$ ed. Rio de Janeiro: Vozes, 1998. BOFF, Leonardo. Saber cuidar: ética do humano - compaixão pela terra. $5^{\underline{a}}$ ed. Rio de Janeiro: Vozes, 1999. CARNEIRO, J. M. Vade-mécum deontológico para fisioterapeutas e terapeutas ocupaciona2is. $2^{\text {a }}$ ed. Rio de Janeiro: Gráfica da UERJ, 1997. Conselho Regional de Fisioterapia e Terapia Ocupacional - CREFITO 6: Legislação. 1994 OLIVEIRA, Juarez. Constituição Federal de 1988: comentários. $2^{a}$ ed. 1998. NALINI, J. R. Ética geral e profissional. São Paulo: Revista dos Tribunais, 1997. Referencial Nacional de 


\begin{tabular}{|c|c|}
\hline & $\begin{array}{l}\text { honorários Fisioterapêuticos. Sistema coffito/crefitos. } 1998 \\
\text { RUSS, Jacqueline. Pensamento ético contemporâneo. São } \\
\text { Paulo: Paulus, 1999. VAZQUEZ, A. S. Ética. 18ª ed. Rio de } \\
\text { Janeiro: Civilização Brasileira, 1998. WEBER, Max. A ética } \\
\text { protestante e o espírito do capitalismo. } 4^{a} \text { ed. Lisboa: Editorial } \\
\text { Presença, } 1996 \text {. }\end{array}$ \\
\hline $\begin{array}{c}\text { Universidade } \\
\text { Alto Vale Do Rio } \\
\text { Do Peixe }\end{array}$ & $\begin{array}{l}\text { BIBLIOGRAFIA BÁSICA: CAMARGO, Marcelino. Fundamentos } \\
\text { de Ética Geral e Profissional. Petrópolis: Vozes, } 1999 . \\
\text { CONSELHO FEDERAL DE FISIOTERAPIA E } \\
\text { TERAPIAOCUPACIONAL. Código de Ética do Fisioterapeuta e } \\
\text { Terapeuta Ocupacional. São Paulo, 1997. DINIZ, Debora; } \\
\text { GUILHEM, Dirce. O que é bioética. São Paulo, Brasiliense, } 2005 . \\
\text { BIBLIOGRAFIA COMPLEMENTAR: CAMARGO, Marcelino. } \\
\text { Ética, Vida e Saúde: Ética Profissional para Cursos na Área da } \\
\text { Saúde. 7a ed. Petrópolis: Vozes, 1983. ANGERAMI-Camon, } \\
\text { VALDEMAR Augusto ((org.)). A ética na saúde. São Paulo, } \\
\text { Pioneira Thomson Learning, 2002. COLBARI, Antonia L. Ética do } \\
\text { Trabalho: a Vida Familiar na Construção da Identidade } \\
\text { Profissional. 2a ed. São Paulo: Letras\& Letras, 1995. } \\
\text { LEPARGNEUR, Humberto. Bioética, Novo Conceito: a Caminho } \\
\text { do Consenso. São Paulo: Loyola, 1996. PALÁCIOS, Marisa } \\
\text { (Org.); MARTINS, André (Org.); PEGORARO, Olinto A. (Org.). } \\
\text { Ética, ciência e saúde: desafios da bioética. Petrópolis, Vozes, } \\
\text { 2002. SEGRE, Marco. Bioética. 2a ed. São Paulo: EDUSP- } \\
\text { Divisão Comercial, 1999. }\end{array}$ \\
\hline $\begin{array}{c}\text { Universidade Do } \\
\text { Contestado - } \\
\text { Unc }\end{array}$ & $\begin{array}{l}\text { BIBLIOGRAFIA BÁSICA: CAMARGO, Marcelino. Fundamentos } \\
\text { de Ética Geral e Profissional. Petrópolis: Vozes, } 1999 . \\
\text { CONSELHO FEDERAL DE FISIOTERAPIA E } \\
\text { TERAPIAOCUPACIONAL. Código de Ética do Fisioterapeuta e } \\
\text { Terapeuta Ocupacional. São Paulo, 1997. DINIZ, Debora; } \\
\text { GUILHEM, Dirce. O que é bioética. São Paulo, Brasiliense, } 2005 . \\
\text { BIBLIOGRAFIA COMPLEMENTAR: CAMARGO, Marcelino. } \\
\text { Ética, Vida e Saúde: Ética Profissional para Cursos na Área da }\end{array}$ \\
\hline
\end{tabular}




\begin{tabular}{|c|c|}
\hline & $\begin{array}{l}\text { Saúde. 7a ed. Petrópolis: Vozes, 1983. ANGERAMI-Camon, } \\
\text { VALDEMAR Augusto ((org.)). A ética na saúde. São Paulo, } \\
\text { Pioneira Thomson Learning, 2002. COLBARI, Antonia L. Ética do } \\
\text { Trabalho: a Vida Familiar na Construção da Identidade } \\
\text { Profissional. 2a ed. São Paulo: Letras\& Letras, } 1995 . \\
\text { LEPARGNEUR, Humberto. Bioética, Novo Conceito: a Caminho } \\
\text { do Consenso. São Paulo: Loyola, 1996. PALÁCIOS, Marisa } \\
\text { (Org.); MARTINS, André (Org.); PEGORARO, Olinto A. (Org.). } \\
\text { Ética, ciência e saúde: desafios da bioética. Petrópolis, Vozes, } \\
\text { 2002. SEGRE, Marco. Bioética. 2a ed. São Paulo: EDUSP- } \\
\text { Divisão Comercial, 1999. SGRECCIA, Elio. Manual de bioética: } \\
\text { aspectos médico-sociais. 2.ed. São Paulo, Loyola, 2004. }\end{array}$ \\
\hline $\begin{array}{l}\text { Universidade } \\
\text { Federal De } \\
\text { Santa Maria }\end{array}$ & $\begin{array}{l}\text { BIBLIOGRAFIA BÁSICA: D'ASSUNPÇÃO, E.A. Comportar-se } \\
\text { fazendo: conceitos de ética para profissionais de saúde. Belo } \\
\text { Horizonte: PUC-MG/FUMARC, 1984; RIOS, T. A. Ética e } \\
\text { Competência. São Paulo: Cortez, 1993. LEGISLAÇÃO } \\
\text { PROFISSIONAL. Resoluções do Conselho Federal de } \\
\text { Fisioterapia e Terapia Ocupacional: Decreto Lei } 938 \text { de 13/10/69 } \\
\text { - Provê sobre as profissões de Fisioterapia e Terapia } \\
\text { Ocupacional. } \\
\text { BIBLIOGRAFIA COMPLEMENTAR: Lei } 6.316 \text { de 17/12/75 - Cria } \\
\text { o COFFITO e os CREFITOS. Lei8.856 de 01/03/94 - Fixa a } \\
\text { jornada de trabalho dos profissionais de Fisioterapia e Terapia } \\
\text { Ocupacional. }\end{array}$ \\
\hline $\begin{array}{c}\text { Universidade } \\
\text { Regional } \\
\text { Integrada Do } \\
\text { Alto Uruguai E } \\
\text { Das Missões }\end{array}$ & $\begin{array}{l}\text { BIBLIOGRAFIA BÁSICA: CREFITO 5. Leis e Atos Normativos } \\
\text { das Profissões do Fisioterapeuta e Terapeuta Ocupacional. } \\
\text { Conselho Regional de Fisioterapia e Terapia Ocupacional da } 5^{\text {a }} \\
\text { Região-CREFITO-5. Porto Alegre, 2001, 2004, 2011. CAMON, } \\
\text { V. A. (organizador). A Ética na Saúde. Editora Pioneira: São } \\
\text { Paulo, 1997. REBELATTO, J. R; BOTOMÉ, S. P. Fisioterapia no } \\
\text { Brasil. Manole: São Paulo, 1999. } \\
\text { BIBLIOGRAFIA COMPLEMENTAR: LEITE, Eduardo de Oliveira } \\
\text { (Coord.). Grandes temas da atualidade: bioética e biodireito. Rio }\end{array}$ \\
\hline
\end{tabular}




\begin{tabular}{|c|c|}
\hline & $\begin{array}{l}\text { de Janeiro: Forense, 2004. SARLET, Ingo Wolfgang. Dignidade } \\
\text { da Pessoa Humana e Direitos Fundamentais na Constituição } \\
\text { Federal de 1988. Porto Alegre: Livraria do Advogado, } 2001 . \\
\text { SARTORI, Giana Lisa Zanardo. Direito e Bioética: o desafio da } \\
\text { interdisciplinaridade. Erechim: EDIFAPES, 2001. SGRECCIA, } \\
\text { Elio. Manual de Bioética. I. Fundamentos e Ética Biomédica. } \\
\text { Trad. Orlando Soares Moreira. São Paulo: Brasil, 1996, } 1997 . \\
\text { Título original: Manuale di bioética. I. Fondamenti ed etica } \\
\text { biomedica. CONSELHO REGIONAL DE FISIOTERAPIA E } \\
\text { TERAPIA OCUPACIONAL (5. REGIÃO).; SCHWINGEL, } \\
\text { Glademir; MOREIRA, Leandro da Rocha; TELES, Perla Cristiane } \\
\text { (Org.). A Fisioterapia e suas vivências na Saúde Pública do Rio } \\
\text { Grande do Sul: relatos de experiências no SUS. Porto Alegre: } \\
\text { Pallotti, } 2007 \text {. }\end{array}$ \\
\hline $\begin{array}{c}\text { Universidade } \\
\text { Federal De Juiz } \\
\text { De Fora }\end{array}$ & $\begin{array}{l}\text { Bioética - Revista publicada pelo Conselho Federal de Medicina } \\
\text {-vol.4, no } 02 \text { Suplemento, 1996; Código de Ética da Fisioterapia } \\
\text { e da Terapia Ocupacional; D'Assumção, Evaldo Alves - } \\
\text { Comportar-se Fazendo Bioética, Petrópolis: Ed. Vozes, 1998; } \\
\text { Segre, Marco e outro. Bioética, São Paulo: Ed. Edusp, 1995; } \\
\text { Vasques, A.S - Ética, Rio de Janeiro: Ed. Civilização Brasileira } \\
\text { S.A,1985. } \\
\text { BIBLIOGRAFIA COMPLEMENTAR: } \\
\text { Engelhardt, Jr H, Tristam - Fundamentos da Bioética -São Paulo: } \\
\text { Edições Loyola, 1998; Gelain, I - Deontologia e Enfermagem } \\
\text { Jorge, C.R. - Relação Terapeuta/Paciente Puc - MG - Cadernos } \\
\text { de Bioética vol.01, abril 1992; Sgreccia, Elio - Manual de } \\
\text { Bioética, São Paulo: Edições Loyola,1999 }\end{array}$ \\
\hline $\begin{array}{c}\text { Universidade } \\
\text { Severino } \\
\text { Sombra }\end{array}$ & $\begin{array}{l}\text { BIBLIOGRAFIA BÁSICA: FORTES, Paulo Antonio de Carvalho. } \\
\text { Ética e saúde: questões éticas, deontológicas legais, autonomia } \\
\text { e direitos do paciente: estudo de casos. São Paulo: EPU, c2002. } \\
119 \text { p.; REIFLER, Hans Ulrich; MOURA, Sergio Siqueira } \\
\text { (Coord.). A ética dos dez mandamentos: um modelo de ética } \\
\text { para os nossos dias. São Paulo: Vida Nova, 2007. } 248 \text { p.; }\end{array}$ \\
\hline
\end{tabular}




\begin{tabular}{|c|c|}
\hline & $\begin{array}{l}\text { CONSELHO REGIONAL DE FISIOTERAPIA E TERAPIA } \\
\text { OCUPACIONAL DA 2 REGIÃO - RIO DE JANEIRO / ESPIRITO } \\
\text { SANTO Crefito - 2. Legislação da fisioterapia e da terapia } \\
\text { ocupacional. Belo Horizonte: CREFITO, 19982002. } 84 \text { p. } \\
\text { BIBLIOGRAFIA COMPLEMENTAR: BOFF, Leonardo. Saber } \\
\text { cuidar: ética do humano - compaixão pela terra. 5. ed. Petrópolis: } \\
\text { Vozes, 2003. } 199 \text { p.; GAUDERER, Christian. Os direitos do } \\
\text { paciente: cidadania na saúde. 7. ed. Rio de Janeiro: Record, } \\
\text { 1998. } 394 \text { p.; SEGRE, Marco; COHEN, Claudio. Bioética. 3. ed. } \\
\text { rev. amp. São Paulo: EDUSP, 2002. } 218 \text { p.; UM OLHAR sobre } \\
\text { ética e cidadania. São Paulo: Mackenzie, 2002. } 145 \text { p. (Coleção } \\
\text { Reflexão Acadêmica ,2) }\end{array}$ \\
\hline Unimar & $\begin{array}{l}\text { BIBLIOGRAFIA BÁSICA: Bernard, J. Da Biologia à Ética: } \\
\text { Bioética. São Paulo: Taricano. 1994. Viana, M. G. Ética Geral e } \\
\text { Profissional. Porto: Livraria Figueirinhas. 1973. Badeia, M. Ética } \\
\text { e Profissionais da Saúde. Santos, 1999. COMPLEMENTAR: } \\
\text { Vasquez, A. S. Ética. Rio de Janeiro: Civilização Brasileira } 1999 . \\
\text { Conselho Federal de Medicina. Iniciação à Bioética. Brasília: } \\
\text { C.F.M. 1998. Oliveira, M. A. Ética e Práxis Histórica. Ed. Cortez, } \\
\text { 1994. }\end{array}$ \\
\hline Unirg & $\begin{array}{l}\text { BIBLIOGRAFIA BÁSICA: SEGRE, Marco; COHEN, Claudio } \\
\text { (Orgs.). Bioética. 3. ed. rev. e ampl. São Paulo: Edusp, } 2002.218 \\
\text { p. ISBN 85-314-304-9.; RIOS, Terezinha Azerêdo. Ética e } \\
\text { competência. 5. ed. São Paulo: Cortez, 1997. } 86 \text { p. (Coleção } \\
\text { questões da nossa época, v. 16). SOARES, André Marcelo M.; } \\
\text { PIÑEIRO, Walter Esteves. Bioética e biodireito: uma introdução. } \\
\text { São Paulo: Loyola, } 2002.135 \text { p. (Coleção gestão em saúde). } \\
\text { BIBLIOGRAFIA COMPLEMENTAR: GUERRA, Arthur Magno e } \\
\text { Silva. Biodireito e bioética: uma introdução critica. Rio de Janeiro: } \\
\text { America Juridica, 2005. } 403 \text { p.; FRANÇA, Genival Veloso de. } \\
\text { Comentários ao código de ética médica. 4. ed. Rio de Janeiro: } \\
\text { Guanabara koogan, 2002. } 305 \text { p. REBELATTO, José Rubens; } \\
\text { BOTOMÉ, Sílvio Paulo. Fisioterapia no Brasil: fundamentos para }\end{array}$ \\
\hline
\end{tabular}




\begin{tabular}{|c|c|}
\hline & $\begin{array}{l}\text { uma ação preventiva e perspectivas profissionais. 2. ed. São } \\
\text { Paulo: Manole, 1999. } 309 \text { p. ROCHA, Guilherme Salgado. Chico } \\
\text { Pinheiro: ética na comunicação. São Paulo: Salesiana, 2000. } 90 \\
\text { p. (Série medalha de ouro). NALINI, José Renato. Ética geral e } \\
\text { profissional. 3. ed. rev. e atual. São Paulo: Revista dos tribunais, } \\
\text { 2001. } 360 \text { p. TEIXEIRA, Sálvio de Figueiredo (Coord.). Direito e } \\
\text { medicina: aspectos jurídicos da medicina. Belo Horizonte: Del } \\
\text { Rey, 2000. } 411 \text { p. } \\
\text { Bibliografia sugerida: } \\
\text { CREFITO. Legislação da fisioterapia e da terapia ocupacional. 3a } \\
\text { ed. BIOÉTICA: NORMAS DE PESQUISA ENVOLVENDO } \\
\text { SERES HUMANOS: RES. CNS 196/96. Brasília: Conselho } \\
\text { Federal de Medicina, v.4, n.2, 1996. } 27 \text { p. Suplemento. }\end{array}$ \\
\hline Unisalesiano & $\begin{array}{l}\text { REFERÊNCIAS BÁSICAS: MEIRA, A. C. H.,ORG.; Ética. } \\
\text { Ensaios interdisciplinares sobre teoria e práticas profissionais, } 6 . \\
\text { ed., SAO JOAO DA BOA VISTA: DIVERSAS, 2006; } \\
\text { BARCHIFONTAINE, C. P.; PESSINI, L.; Problemas atuais de } \\
\text { bioética, 8.ed., São Paulo: Loyola, 2007; Conselho Federal de } \\
\text { Fisioterapia e Terapia Ocupacional. Código de Ética Profissional } \\
\text { de Fisioterapia e Terapia Ocupacional, 1975. } \\
\text { REFERÊNCIAS COMPLEMENTARES: } \\
\text { BARCHIFONTAINE, C.P., Problemas atuais de bioética, 6. ed., } \\
\text { São Paulo, Loyola, 2002; COHEN, C.,O.; SEGRE, M.,O.; } \\
\text { Bioética, São Paulo: Edusp, 2002; BOFF, L.; Ética e moral: a } \\
\text { busca dos fundamentos. Petrópolis, Vozes, 2003; LEWIS, R.; } \\
\text { Genética Humana. Conceitos E Aplicações, Rio de Janeiro: } \\
\text { Guanabara Koogan, 2004. }\end{array}$ \\
\hline
\end{tabular}

Fonte: Sites das Universidades e Centros Universitários selecionados para o estudo.

As referências bibliográficas da disciplina de ética e deontologia mostra-se de forma variada. Somente quatro livros foram citados em comum, demonstrando que não há um censo comum da abordagem da ética e deontologia entre as instituições.

Quanto à titulação do professor que ministra a disciplina de ética e ou Deontologia, somente uma instituição a apresentou (mestre), porém após análise do 
currículo lattes do docente, observou-se que o mesmo não apresentava trajetória acadêmica relacionada com a disciplina, não havendo cursos de formação ou aperfeiçoamento, livros, artigos, orientações ou participação em bancas de defesa que abordassem o tema em questão.

\subsection{Bioética vinculada a outra disciplina}

Das instituições pesquisadas, 25 apresentavam a disciplina de bioética vinculada a outro conteúdo como: Biodireito, Legislação Fisioterapêutica, Deontologia, Ética, Saúde e Sociedade, Metodologia da Pesquisa, Diversidade, Ciências Sociais e Introdução a Fisioterapia.

\section{5. Ética vinculada a outra disciplina}

E 29 instituições apresentavam a disciplina de ética vinculada a outro conteúdo como: Filosofia, Política e Sociedade, Cidadania, Legislação e Empreendedorismo, Pesquisa, Administração em Fisioterapia, Cultura Religiosa, Gestão, História e Fundamentos em Fisioterapia, Responsabilidade Social e Relações Humanas e Sociais.

5.6. Disciplina que apresentava em seu conteúdo programático temas relacionados a Ética, Bioética e Deontologia

Algumas instituições que apresentavam informações sobre o plano de ensino, foi possível analisar as que a disciplina, que não levasse o nome de ética, bioética e deontologia, mas apresentavam em seu conteúdo programático ou ementa temas relacionados $(n=6)$. Dentre as disciplinas encontrou-se: Práticas Integradas, Desenvolvimento Humano, Introdução a Fisioterapia, Ética Geral, História e Fundamentos de Fisioterapia e Legislação e Gestão em Fisioterapia.

Após esta análise final das disciplinas de ética e ou deontologia e bioética abordadas em conjunto com outros conteúdos nas instituições, observou-se que não há completa sobreposição de abordagem. Ainda que haja temas em comum nas ementas, a leitura das mesmas revelou que os temas parecem ser abordados de 
forma isolada e sem aprofundamento, podendo predominar a temática bioética, não havendo tempo suficiente para abordar os outros conteúdos. 


\section{DISCUSSÃO}

Com base nos resultados, foi evidenciado uma lacuna curricular quanto à inserção da disciplina de bioética nos cursos de fisioterapia das Universidades e Centros Universitários do Brasil. A sua introdução nas matrizes curriculares ainda tem sido lenta, comprovado pelo fato de apenas 17 Instituições a apresentarem. Resultado similar foi encontrado no estudo de Zanatta e Boemer (2007) quanto ao curso de Enfermagem em Riberão Preto (SP), demonstrando que a carência desta disciplina nos currículos da área da saúde é patente ${ }^{64}$.

Segundo Parecer CNE/CES 4/2002 (CONSELHO NACIONAL DA EDUCAÇÃO, 2002) que aprova as diretrizes curriculares nacionais para cursos de fisioterapia, os princípios da ética, bioética e a tomada de decisões constam como requisitos essenciais a serem trabalhados ${ }^{45}$. Espera-se então que:

Os profissionais devem realizar seus serviços dentro dos mais altos padrões de qualidade e dos princípios da ética/bioética, tendo em conta que a responsabilidade da atenção à saúde não se encerra com o ato técnico, mas sim, com a resolução do problema de saúde, tanto em nível individual como coletivo; O trabalho dos profissionais de saúde deve estar fundamentado na capacidade de tomar decisões visando o uso apropriado, eficácia e custo efetividade, da força de trabalho, de medicamentos, de equipamentos, de procedimentos e de práticas. Para este fim, os mesmos devem possuir competências e habilidades para avaliar, sistematizar e decidir as condutas mais adequadas, baseadas em evidências científicas. (CONSELHO NACIONAL DE EDUCAÇÃO, 2002) ${ }^{45}$

Urge, pois, que a inserção das abordagens bioéticas como conteúdo básico possibilite conciliar a qualificação científica e tecnológica com um forte embasamento ético-moral para guiar as práticas do fisioterapeuta no exercer da sua profissão, conforme sugeriram Zanatta e Boemer $(2007)^{64}$.

Mesmo não sendo satisfatório o número de instituições que incluem a bioética no seu currículo (17 de 123 Instituições), revela-se que nestas universidades e centros universitários há preocupação em atender as exigências das diretrizes curriculares e suprir a demanda atual pelo ensino da bioética.

Entretanto, persiste ainda a necessidade de incluir a fundamentação dos princípios bioéticos nos cursos de fisioterapia no Brasil, uma vez que o respeito à dignidade e a autonomia do ser humano e o cuidado com a saúde dos pacientes são 
deveres inequívocos dos fisioterapeutas. Essa não é uma tarefa fácil frente à persistente problemática relacionada à desmobilização dessa categoria profissional. É possível dizer que essa situação tem origem na formação tecnicista, na crescente demanda do mercado de trabalho, na proliferação desenfreada de cursos de graduação em fisioterapia e na competição gerada pelo aumento do número de profissionais formados a cada semestre. Justamente por isso é preciso rever e adotar conceitos e práticas éticas para conseguir superar as demandas internas e enfrentar com dignidade e autonomia os dilemas decorrentes da inserção desses profissionais no espaço social em que atuam ${ }^{6}$.

A importância da formação bioética dos profissionais da saúde é conhecida e problematizada há várias décadas. $O$ ensino dessa disciplina é uma tarefa que exige mobilidade e criatividade e também a modificação dos moldes tradicionais adotados na maioria das universidades. Além disso, a organização da ementa da disciplina implica, também, em cuidado especial para que não seja apenas o novo nome das antigas disciplinas encarregadas dos aspectos disciplinares e legais das práticas profissionais ${ }^{40}$.

Segundo Mónica Rincón R. e demais autores (2008), na formação dos profissionais da saúde deve estar incluída a cátedra de bioética dentro do currículo. A disciplina deve estar explícita demonstrando a necessidade do aprendizado teórico e prático dos estudantes. Os profissionais da saúde devem ser capazes de atuar com suficiente competência e desempenho para que possam dirimir os conflitos morais relacionados com a aplicação dos avanços tecnológicos através da aplicação prática da ética clínica"65.

Nesse ponto, ao possibilitar uma educação bioética permite-se a inclusão da educação em valores no ensino de ciências. Mas, os professores deverão reconhecer que não poderão deixar de auxiliar os seus alunos a desenvolverem futuramente habilidades essenciais para a reflexão sobre algum tipo de problema e sobre as dimensões sociais, políticas e éticas que envolvem qualquer tomada de decisão do cidadão. Pois, cada sujeito da sociedade sofre as influências mesmo sem percebê-las que a ciência exerce em suas vidas cotidianas ${ }^{39}$.

Como forma de minimizar conflitos bioéticos durante a atuação profissional seja nos estágios supervisionados ou mesmo após a formação superior - os educadores podem utilizar estratégias diferenciadas para o processo ensinoaprendizagem. Durante suas exposições podem ser incluídos: debates e seminários 
em sala de aula, estudos de caso baseados em situações concretas e persistentes encontradas nas práticas clínicas da profissão, filmes que evidenciam situações conflituosas e com isso estimular o aluno a julgar, raciocinar e tomar a decisão que ele considerar mais acertadas sem excluir o valor sentimental ${ }^{40}$.

No entanto, persiste a necessidade de maior discussão sobre a importância da bioética na formação acadêmica, pois a identificação e o enfrentamento dos conflitos éticos são distintos a depender de cada profissão. Dessa forma, torna-se imperativo o desenvolvimento de estudos mais amplos sobre reflexões bioéticas específicas para a formação dos profissionais da fisioterapia, promovendo a educação permanente, resguardando o lócus da construção transdisciplinar ${ }^{40}$.

Diante dos resultados, para cumprir o objetivo deste estudo, questiona-se os temas abordados dentro da disciplina de bioética, o momento em que se dá a disciplina, sua abrangência e sua aplicação prática ao longo de todo o curso. Acreditase que uma postura ética não se constrói com apenas algumas aulas ministradas ao aluno assim que ingressa no curso. Desta forma é possível informar os alunos, mas não formá-los ${ }^{62}$.

Essa informação condiz com os resultados deste estudo, onde pôde-se observar que a disciplina de bioética é ministrada somente em um semestre do curso de fisioterapia, assim como a disciplina de ética e deontologia, e dessa forma, não foi encontrado outras disciplinas que pudessem continuar abordando os temas bioéticos ao longo da formação profissional. Além da mesma ser abordada do início ao meio do curso. O processo do aprendizado da bioética parece ficar truncado se não há uma continuidade de reflexão e do exercício de aplicação dos valores em questão a casos concretos. É necessário envolver o ensino da bioética numa forma transversal em todos os níveis de formação da graduação65,66.

Cabe ressaltar, entretanto, que o ensino de ética e bioética tenderia a ser mais profícuo se não se restringisse a disciplinas do início do curso, mas fosse também ministrado de forma transdisciplinar e transversal ao longo da graduação e durante dos estágios supervisionados, conforme apontado por Siqueira (2012)67. O mais adequado à formação bioética e ética do profissional de saúde, em especial do fisioterapeuta, seria: 1. a introdução de conteúdos ministrados nas disciplinas básicas do estágio, com noções gerais de ética, e 2. um curso teórico e substantivo de introdução à bioética, a ética aplicada ao ambiente de ensino e relativa ao respeito ao paciente, aos mestres, animais de experiências e até à postura acadêmica. 
Em síntese, discussões em bioética devem ocupar todos os momentos possíveis da formação acadêmica dos profissionais de saúde. É preciso considerar, do mesmo modo, que dificilmente essas questões podem ser aprisionadas em programas disciplinares fixos, já que normas morais são construídas ao longo do tempo, sendo transmitidas, modificadas e enriquecidas a cada avanço da ciência e de novas posturas adotadas pela sociedade. Essa condição torna incompatível o ensino de ética e bioética por meio de metodologia convencional de transmissão passiva do conhecimento e em carga horária tão reduzida como a ofertada presentemente no currículo da maioria dos cursos da área da saúde, em especial, da fisioterapia ${ }^{68}$.

Diante disso, alerta-se ao fato da bioética ser subestimada na grade curricular no curso de fisioterapia, assim como a ética e deontologia, evidenciando que, em um curso com carga horária total superior a 4000 horas, apenas 30 ou 40 são destinadas a disciplina de bioética ou ética. Tal fato vem sendo observado desde 2003 quando Siqueira em seu artigo observou que em um curso de Medicina com carga horária total de 8640 horas, apenas 50 eram destinadas à disciplina de bioética ${ }^{67}$. Tal fato também é confirmado no estudo de Hellmann e Verdi (2013) que observou que a carga horária das disciplinas gerais que se ocupavam diretamente do estudo da ética, bioética e deontologia variou de 30 a 60 horas-aula ${ }^{69}$.

Dessa forma, existe uma contradição entre o discurso de valorização da ética e o tratamento dispensado a essa disciplina no âmbito do currículo do curso de fisioterapia pois, em algumas instituições, ela é a disciplina com menor carga horária. Isso faz com que a carga horária seja insuficiente para desenvolver um conteúdo que permita aos alunos desenvolverem posturas amadurecidas, frente aos dilemas bioéticos com os quais se defrontarão durante a vida profissional.

Para contribuir na formação acadêmica, não apenas a carga horária das disciplinas se faz relevante, mas também a formação dos professores ${ }^{70}$. Nesse sentido, Figueiredo, Garrafa e Portillo (2008), em estudo acerca do ensino de bioética na área das ciências da saúde no Brasil, mencionam a escassa formação do corpo docente, bem como a inexistência de levantamentos para mensurar quem são esses profissionais ${ }^{48}$. Referindo-se ao ensino médico, Rego (2003) aponta o crescente número de novas faculdades, que contratam professores desatualizados e, muitas vezes, não preparados para o ensino da ética ${ }^{70}$.

No presente estudo não foi possível realizar análise mais aprofundada sobre a formação acadêmica do docente que ministra a disciplina de ética e ou deontologia e 
bioética, pois nos sites das Instituições não citam o nome dos professores "em domínio público" responsáveis. Dessa forma, só foi possível identificar dois docentes, onde um havia realizado recentemente um curso de bioética e o outro não apresentava nenhuma trajetória acadêmica relacionada ao tema, após a análise dos seus currículos lattes. Um contato com as instituições de ensino para identificar os professores e suas formações seria essencial para complementar esse dado do estudo.

A análise das ementas revelou o predomínio da abordagem temática, corroborando o exposto por Diniz e Guilhem (2002) quanto à abordagem dominante no Brasil62. Entretanto, sendo a bioética uma disciplina constituída por diferentes teorias e fundamentações que surgiram paulatinamente no seu processo de consolidação, é pertinente afirmar que seu ensino em uma perspectiva histórica e filosófica poderá ampliar a compreensão do seu significado e importância, conforme sugerem as mesmas autoras. Mesmo porque, limitar a abordagem bioética à análise de exemplos pontuais inibe o desenvolvimento da visão crítica, o julgamento e o posicionamento adequado dos sujeitos diante de situações profissionais de conflito moral que não são contemplados na abordagem puramente temática ${ }^{60}$.

A análise temática é a mais é utilizada pelos iniciantes na bioética, especialmente por aqueles que ainda não dominam o conhecimento a ponto de construíram uma argumentação em termos filosóficos ou mesmo históricos. Entretanto, a abordagem mais sedutora das três é a abordagem historicista, pois permite que tanto professores quanto estudantes apoiem-se em informações acumuladas anteriores à pesquisa em bioética. Com certa regularidade, os adeptos da abordagem historicista iniciam suas incursões bioéticas referindo-se às duas guerras mundiais, aos campos de concentração do estado nazista e às pesquisas dos médicos alemães dessa época, aos tratados internacionais (Helsinki e a Declaração Universal dos Direitos do Homem estão entre os mais citados), às mudanças socioculturais vividas pelos países ocidentais nos anos sessenta e setenta (emancipação feminista, movimento hippie, revolução sexual, somente para citar alguns), culminando com a elaboração e divulgação, nos Estados Unidos, do Relatório Belmont, da Comissão Nacional para a Proteção dos Seres Humanos da Pesquisa Biomédica e Comportamental, em 1978. De posse deste quadro histórico de acontecimentos recentes da história euro americana, os simpatizantes da abordagem 
historicista sugerem uma análise baseada nas mudanças de valores morais decorrentes do impacto que esses fatos provocaram na vida dos seres humanos ${ }^{71}$.

Embora pareça que esta realidade está sendo alterada, além do predomínio da abordagem temática, também foi observado nos conteúdos programáticos, em especial, que as questões médicas e biotecnológicas são abordadas com maior ênfase do ponto de vista ético. Este fato reflete o histórico da consolidação da bioética no Brasil que foi importada dos Estados Unidos onde casos biomédicos e tecnológicos são priorizados ${ }^{60}$.

O grande problema dessa realidade é que, considerando-se o curso de fisioterapia, a abordagem da bioética centrada nos problemas biomédicos e tecnológicos torna-se insuficiente para consubstanciar moralmente a reflexão acerca do exercício profissional e dos dilemas bioéticos enfrentados na prática profissional. Este fato torna-se mais dificultado pelo fato da disciplina não ter uma padronização nacional e acabar sendo abordada juntamente com outros temas como Ética, Ética Profissional, Biodireito, Consentimento Informado e Pesquisa.

Observa-se que a bioética, como uma disciplina isolada, ainda não conseguiu provocar as mudanças desejadas; é preciso que todas as estruturas físicas e humanas da instituição de ensino superior estejam em sintonia com um mesmo quadro de valores e posturas. É interessante notar, como o faz Villamil (2007) no estudo Pertinência de la bioética global en la educación universitária, que já nos primórdios, segundo o pensamento de Potter a bioética deveria chegar a ser um novo estilo para fazer ciência sobre a vida, para educar sobre a mesma, que seja transdisciplinar e que integre a biologia no sentido amplo da palavra, os valores humanos, os problemas do meio ambiente e dos seres vivos que intervém na preservação e na melhoria da própria qualidade de vida dos seres humanos ${ }^{72}$.

A bioética desenvolve a reflexão sobre dilemas de cunho ético a respeito de toda e qualquer ação que tenha efeitos sobre a vida humana, como por exemplo, a reabilitação no processo do cuidar cujo agente é o fisioterapeuta. O ensino da bioética promove o desenvolvimento de princípios universais que orientam o crescimento tecnológico, a pesquisa científica e a resolução de conflitos morais. Não se trata de transmissão de valores acabados; o aluno é incentivado a pensar por si mesmo, a decidir usando sua autonomia e a estar aberto a novos conceitos e linhas de pensamento. O diálogo entre pessoas que seguem linhas de pensamentos 
divergentes enriquece o processo de formação do juízo ético. Assim, há a colaboração para a transformação da sociedade, para que ela se torne mais justa ${ }^{66}$.

Já o ensino da ética para os profissionais de saúde, em especial para o fisioterapeuta, é voltado, classicamente, para a deontologia. O ponto frágil deste ensino está na impossibilidade de refletir sobre dilemas éticos que surgem com o avanço do progresso científico e tecnológico. Além disso, frente aos conflitos éticos, as normas não devem aplicar-se apenas por conveniência, mas por convicção. Para isso, é preciso que a formação moral mostre os elementos necessários para que se entenda o porquê das normas e para que sejam aceitas de maneira crítica ou, até mesmo, sejam alteradas se preciso. A existência de um código moral não garante a coexistência de uma ética, ou seja, de uma reflexão sobre os significados morais.

Recentemente, o Código de Ética da Fisioterapia foi reestruturado. Após análise bioética do antigo e do novo código e de textos com referenciais bioéticos e deontológicos, que no antigo código prevaleceu concepções corporativistas e legalistas que privilegiava a autonomia profissional em relação a autonomia do cliente. No entanto, houve evolução de conteúdo que envolve as questões bioéticas no novo código, tornando-o mais próximo dos referenciais das questões bioéticas, principalmente na redução da proporção da autonomia profissional sobre a autonomia do cliente e no aumento de conteúdos com enfoque bioético no novo código ${ }^{71}$.

Entretanto, tanto no antigo quanto no novo código, ainda é evidente a grande característica deontológica. No antigo há predomínio de categorias deontológicas e no novo predomínio de categorias bioéticas, ainda é grande a quantidade de citações com referenciais deontológicos ${ }^{72}$. Tal fato pode ser explicado tanto pelo surgimento do primeiro código de ética, anterior ao conhecimento mais profundo das questões bioéticas, quanto pela preocupação com a desvalorização profissional, mediante condições desfavoráveis à sua prática e desrespeito entre os próprios profissionais, estas últimas ocasionadas pela negligência nas discussões sobre ética e bioética ${ }^{74,75}$.

Faz-se necessária a constante reflexão acerca dos códigos deontológicos das profissões, a fim de que o exercício profissional seja capaz de contribuir para uma sociedade justa. No âmbito do ensino de deontologia nos cursos de fisioterapia, essa premissa não é diferente ${ }^{69}$. 


\section{CONCLUSÃO}

As matrizes curriculares dos cursos de graduação em fisioterapia dos Centros Universitários e Universidades brasileiras estão em dissonância com a necessidade de se formar profissionais fortemente pautados em valores bioéticos. É necessário o incremento do conteúdo de Bioética nesses cursos de modo a promover uma reflexão crítica dos acadêmicos e para que os mesmos enfrentem os dilemas éticos, construam autonomamente os seus conceitos como agentes morais e pratiquem a Bioética em sua futura atividade profissional.

Considera-se que o investimento acadêmico tem sido ainda muito pequeno e incipiente, sem grandes possibilidades para reflexão. Isso é comprovado pela pequena carga horária (30 - 40 horas) destina à disciplina de bioética e ou ética e ou deontologia para formar, nos alunos, consciência no processo de tomada de decisão.

Os resultados obtidos também permitem concluir que os maiores desafios contemporâneos na formação do fisioterapeuta incidem na necessidade de romper a vigência dos sistemas éticos tradicionais no ensino superior e suprir as lacunas curriculares quanto ao acesso às abordagens bioéticas. Somente assim será possível contemplar maior diversidade de questões éticas e bioéticas para além da compreensão ou apenas conhecimentos do código de ética.

Para que isso ocorra, é preciso maior estímulo dos docentes para com seus alunos e dos pesquisadores da área de bioética em desenvolver estudos que estimulem as instituições de ensino superior a incorporar em suas matrizes curriculares dos cursos de fisioterapia a disciplina de bioética.

Mas é necessário também uma maior abordagem por parte dos coordenadores e docentes que propõem as ementas da disciplina de bioética. A abordagem temática, como está posto hoje, é importante, porém a mesma não oferece uma base fundamental para os estudantes e futuros profissionais lidarem com os conflitos das relações e as decisões clínicas que estão presentes no dia-a-dia da prática profissional.

Dessa forma, propõe-se após os resultados e análise deste estudo que os ementários sejam construídos não somente visando a abordagem temática, mas também as abordagens historicista e filosófica, com maior ênfase na filosófica pois esta possui uma corrente teórica fundamental para proporcionar ao aluno uma melhor reflexão e entendimento sobre os conflitos éticos e assim ajudá-lo a solucionar os 
mesmos. Mas será que somente exposições teóricas e de casos clínicos seria o suficiente para conseguir alcançar este objetivo?

É diante deste questionamento que se sugere uma mudança na abordagem metodológica da disciplina de bioética por parte dos docentes. O ensino da bioética pode ser efetuado de distintas formas. Alguns exemplos são: exposição de casos vivenciados pelos próprios docentes ou colegas de profissão fisioterapeutas ou da equipe multidisciplinar, observação das relações que se estabelecem ao campo de estágio entre estagiário-paciente, docente-paciente, estagiário-estagiário e docentedocente, e também através da abordagem da bioética durante a realização do estágio por parte dos orientadores de prática. Dessa forma, a bioética como disciplina deveria ser ministrada, separado da disciplina de ética, no máximo um semestre antes do início dos estágios supervisionados e com uma carga horária de no mínimo 60 horas para que todos os temas possam ser abordados de forma ampla, abrangendo o processo filosófico, histórico e temático aplicado a fisioterapia.

Acredita-se que os alunos chegariam mais preparados e maduros para vivenciar a prática clínica conforme o sugerido acima. Nessa fase ele provavelmente já teria cursado a disciplina de ética e deontologia para saber como portar-se quanto profissional de saúde. Porém, como já mencionado, tal disciplina que aborda o Código de Ética Profissional não é suficiente para preparar o aluno para lidar com os conflitos éticos visando sempre o bem-estar pessoal e do próximo.

Essas sugestões de mudança de ementário, semestre da disciplina e aumento da carga horária podem futuramente se tornar um novo objeto de estudo. Para que isso se torne real seria necessário que a Instituição de Ensino Superior que estivesse sob mudança Projeto Pedagógico de Curso e matriz curricular aderissem à mudança e ou inclusão da disciplina de bioética e comparassem a evolução pessoal e profissional do aluno mediante colocações de situações conflituosas com alunos que não tiveram a disciplina de bioética ou a cursaram no início do curso.

A partir esta reflexão espera-se aumentar a sensibilização de coordenadores e docentes do curso de fisioterapia em adicionar nas suas matrizes curriculares a disciplina de Bioética e avaliar a evolução do aluno frente a tomadas de decisões. Assim, sugere-se o planejamento de novos estudos com acompanhamento dos alunos que cursaram ou não a disciplina de bioética, com amostras de tamanho suficiente. 


\section{REFERÊNCIAS}

1. Marques WL. Ética no trabalho. $1^{a}$ ed. Paraná: Gráfica Vera Cruz, 2010.

2. Novaes MRCG, Guilhem D, Novaes LCG, Lolas F. Diagnóstico de la inserción de la ética en la carrera de medicina en Brasil. Educ méd. 2010;13(4):239-46.

3. Kipper DJ. Ética teoria e prática: uma visão multidisciplinar. $1^{\text {a }}$ ed. Porto alegre: Edipucrs, 2006.

4. Machado $D$, Carvalho $M$, Machado $B$, Pacheco $F$. A formação ética do fisioterapeuta. Fisioterapia em movimento. 2007;20(3):101-105.

5. Lolas F. Bioética: o que é, como se faz. 2ª ed. São Paulo: Edições Loyola, 2005.

6. Badaró AFV. Ética e bioética na práxis da Fisioterapia: Desvelando comportamentos. (tese). Brasília (DF): Universidade de Brasília, 2008.

7. Mellado SR. Universidades Y Docencia en Bioética. 1a. edición. Alicante: Editorial Clube Universitario, 2004.

8. Rebelatto JR, Botomé SP. Fisioterapia no Brasil: fundamentos para uma ação preventiva e perspectivas profissionais. $2^{\mathrm{a}}$ ed. São Paulo: Manole, 2011.

9. Poulis I. Bioethics and physiotherapy. J Med Ethics. 2007;33:435-436.

10. Delany CM, Edwards I, Jensen GM, Skinner E. Closing the Gap Between Ethics Knowledge and Practice Through Active Engagement: An Applied Model of Physical Therapy Ethics. Physical Therapy. 2010;90(7):1068-1078.

11. Swisher LL. A retrospective analysis of ethics knowledge in Physical Therapy (1970 - 2000). Phys Ther. 2002;82:692-706.

12. Edwards I, Braunack-Mayer A, Jones M. Ethical reasoning as a clinicalreasoning strategy in physiotherapy. Physiotherapy. 2005;95:229-236.

13. Greenfield $\mathrm{BH}$. The meaning of caring in five experienced physical therapists. Physiother Theory Pract. 2006;22(4):175-187.

14. Barros FBM. Autonomia Profissional do Fisioterapeuta ao longo da história. Revista FisioBrasil. 2003;59:20-31.

15. MEC. A trajetória dos cursos de graduação na área de saúde: 1991-2004. In: Haddad AE, editor. Brasília: Instituto Nacional de Estudos e Pesquisas Educacionais Anísio Teixeira; 2006.

16. Barros FBM. Profissão Fisioterapeuta - História social, legislação, problemas e desafios. $1^{\mathrm{a}}$ ed, Rio de Janeiro: Editora Agbook; 2011. 
17. Sanchez EL. Histórico da Fisioterapia no Brasil e no Mundo. Rev. Atual. Bras. Fisioter. 1984;1(3):29-36.

18. ABBR. Ata da Assembléia Geral de Constituição da Associação Brasileira Beneficente de Reabilitação (1956). Cartório Civil de Pessoa Jurídica, Rio de Janeiro.

19. Barros FBM. Poliomielite, filantropia e fisioterapia: o nascimento da profissão de fisioterapeuta no Rio de Janeiro dos anos 1950. Ciênc. saúde coletiva. 2008;13(3):941-54.

20. Nascimento CC. Oficina de trabalho corporal em um serviço de saúde mental. (Dissertação). Riberão Preto: Universidade de São Paulo, 2011.

21. Marques AP, Sanches ES. Origem e evolução da Fisioterapia: aspectos históricos e legais. Rev Fisioter Univ São Paulo. 1994;1(1):5-10.

22. COFFITO. Conselho Federal de Fisioterapia. Fisioterapia: legislação, definições e áreas de atuação.

23. Calvalcante CCL, Rodrigues ARS, Dadalto TV, da Silva EB. Evolução científica da fisioterapia em 40 anos de profissão. Fisioter Mov. 2011;24(3):513-22.

24. Bispo Junior JP. Formação em fisioterapia no Brasil: reflexões sobre a expansão do ensino e os modelos de formação. Hist. cienc. saudeManguinhos. 2009;16(3):655-68.

25. Pereira LA, Almeida M. Fisioterapia. In: Fundação Oswaldo Cruz. Dinâmica das graduações em saúde no Brasil: subsídios para uma política de recursos humanos. Brasília: Ministério da Saúde. 2006;171-84.

26. Ferreira ABH. Mini Aurélio: o dicionário da língua portuguesa. 6ae ed. Rev. Atual. Curitiba: Positivo, 2005.

27. Cortina A, Martínez E. Ética. $3^{\underline{a}}$ ed. São Paulo: Ed. Loyola, 2012.

28. Brasil. Secretaria de Educação Fundamental. Parâmetros curriculares Nacionais: apresentação dos temas transversais, Ética. Secretaria de Educação Fundamental. Brasília: MEC/SEF, 1997.

29. Goldim, JR. Bioética: Origens e Complexidade. Rev HCPA. 2006;26(2):86-92.

30. Souza ML, Sartor VVB, Prado ML. Subsídios para uma ética da responsabilidade em Enfermagem. Texto contexto - enferm. 2005;14(1):75-81.

31. Carvalho VA, Macieira RC, Liberato RP, Veit MT, Kovács MJ, Gomes MJB, et al. Temas em Psico-oncologia. 1를 ed. São Paulo: Summus Editorial, 2008. 
32. Carapeto C, Fonseca F. Ética e Deontologia - Manual de Formação. Lisboa: Dossier, Comunicação e Imagem, 2012.

33. Neto ACB, Silva KV, Araújo EC. Importância da Bioética na formação do enfermeiro para o atendimento do adolescente enfermo crônico. REME - Rev. Min. Enf. 2007;11(2): 205-9.

34. Milcent PF. Etigenia. Ética, moral e engenharia: análise do ethos para engenheiros. $1^{\underline{a}}$ ed. Curitiba: Edição do Autor, 2014.

35. Giovanella L, Escorel S, Lobato LVC, Noronha JC, Carvalho Al. Políticas e sistema de saúde no brasil. 2ª̣Ed. Rio de Janeiro: Editora Fiocruz, 2013.

36. Daolio ER. Os significados e os motivos do Suicídio: as representações sociais de pessoas residentes em Bragança Paulista, SP. (dissertação). Pouso Alegre: UNIVÁs; 2006.

37. Pessine L, Barchifontaine CP. Bioética: alguns desafios. $2^{\underline{a}}$ ed. São Paulo: Edições Loyola, 2002.

38. Conti MCS. Biodireito: A norma da vida. $1^{\text {a }}$ ed. Rio de Janeiro: Editora Forense; 2004.

39. Pereira TL, Sánchez C. A bioética e o ensino de ciências: algumas reflexões. Ciência em Tela. 2010;3(1):1-7.

40. Paiva L, Guilhem D, Souza ALL. O Ensino de Bioética na Graduação do Profissional de Saúde. Medicina (Ribeirão Preto). 2014;47(4): 357-69.

41.Zancan LF. Dilemas morais nas políticas de saúde: o caso da AIDS. Uma aproximação a partir da bioética. (Dissertação). Fundação Oswaldo Cruz, Escola Nacional de Saúde Pública; 1999.

42. Gracia D. Ética y Vida I: Fundamentación y enseñanza de la Bioética. Santa Fé de Bogotá: Editorial El Búho, 1998.

43. Beauchamp TL, Childress JF. Principles of Biomedical Ethics. $4^{\mathrm{a}}$ ed. New York: Oxford University Press, 1994.

44. Santos LR, Leon CGRMP, Funghetto SS. Princípios éticos como norteadores no cuidado domiciliar. Cien Saude Colet. 2011; 16(Supl. 1):855-863.

45. Brasil. Conselho Nacional de Educação. Câmara de Educação Superior. Resolução no CNE/CES, 19 fev. 2002. Diretrizes curriculares nacionais do curso de graduação em Fisioterapia. Diário Oficial, Brasília, DF, ㄲo 42, seção 14 mar. 2002.

Disponível

em: http://portal.mec.gov.br/cne/arquivos/pdf/CES042002.pdf 
46. RESOLUÇÃO CNE/CES 4, DE 19 DE FEVEREIRO DE 2002. Institui Diretrizes Curriculares Nacionais do Curso de Graduação em Fisioterapia.

47. Catani AM, Oliveira JF, Dourado LF. Política educacional, mudanças no mundo do trabalho e reforma curricular nos cursos de graduação no Brasil. Educação \& Sociedade. $2001 ; 22(75): 67-83$.

48. Figueiredo AM, Garrafa V, Portillo JAC. Ensino da Bioética na área das Ciências da Saúde no Brasil: Estudo de Revisão Sistemática. Rev INTERthesis. 2008;5(2):47-72.

49. Freitas M. A Atenção Básica como Campo de Atuação da Fisioterapia no Brasil: as Diretrizes Curriculares resignificando a prática profissional. (Tese). Rio de Janeiro: Universidade do Estado do Rio de Janeiro, 2006.

50. Couceiro-Vidal A. Enseñanza de la bioética y planes de estudios basados en competencias. Educ méd. 2008; 11(2): 69-76

Nascimento CC. Oficina de trabalho corporal em um serviço de saúde mental. (Dissertação). Universidade de São Paulo: Ribeirão Preto, 2011.

51. Diniz D, Sugai A, Guilhem D, Squinca F. Ética em pesquisa: temas globais. 1ª ed. Brasília: Editora UnB; 2008.

52. ALVES FD, Bigongiari A, Mochizuki L, Hossne WS, Almeida M. O preparo bioético na graduação de Fisioterapia. Fisioter. Pesqui. 2008;15(2):149-56.

53. CONSELHO REGIONAL DE FISIOTERAPIA E TERAPIA OCUPACIONAL. CREFITO. 2011. Disponível em: http://www.crefito.org.br/fisioterapia.

54. Rezende M. Avaliação da Inserção do Fisioterapeuta na Saúde da Família de Macaé/RJ: A Contribuição deste Profissional para a Acessibilidade da População Idosa às Ações de Saúde da Equipe. Um Estudo de Caso. (Dissertação). Escola Nacional de Saúde Pública Sergio Arouca, Fundação Oswaldo Cruz, Rio de Janeiro, 2007.

55. Neto ACB, Silva KV, Araújo EC. Importância da Bioética na formação do enfermeiro para o atendimento do adolescente enfermo crônico. Rev. Min. Enferm. 2007;11(2):205-9.

56. Praestegaard J, Gard G. The perceptions of Danish physiotherapists on the ethical issues related to the physiotherapist-patient relationship during the first session: phenomenological approach. BMC Medical Ethics. 2011;12(21):1-11. 
57. Figueiredo LC, Gratão ACM, Martins EF. Código de ética para fisioterapeutas e terapeutas ocupacionais revela conteúdos relacionados à autonomia profissional. Fisioter Pesq. 2013;20(4):394-400.

58. Lorenzo CFG, Bueno GTA. A interface entre bioética e fisioterapia nos artigos brasileiros indexados. Fisioter Mov. 2013;26(4):763-75

59. Heck JN. Bioética: contexto histórico, desafios e responsabilidade. Ethic@. 2005;4(2):123-39.

60. Dória TAF, Moreira LMA. A bioética na formação do biólogo: um desafio contemporâneo. R. FACED. 2011;20:99-122.

61. Costa SIF, Diniz D. Introdução à bioética. 1를 ed. Brasília: Letras Livres, 2001.

62. Diniz D, Guilhem D. O que é bioética. 1ํe ed. São Paulo: Brasiliense, 2002.

63. Bardin L. Análise de conteúdo. Lisboa: Edições 70; 2009.

64. Zanatta JM, Boemer MR. Bioética: uma análise sobre a sua inserção nos cursos de graduação em enfermagem em uma região do Estado de São Paulo. Bioethikos. 2007;1(2):63-69.

65. Rincón M, Becerra LMC, Camargo MAL, Guzmán MPG, Cardona NAG, López $A O$, et ál. Bioética y toma de decisiones éticas en unidades de cuidado intensivo. Rev Latinoam Bioet. 2008;8(2):114-23.

66. Puplaksis NV, Pereira da Silva MM, Nobile R, Ramos DLP. A disciplina de bioética na Faculdade de Odontologia da Universidade de São Paulo. Rev Latinoam Bioet. 2010;10(2):68-75.

67. Siqueira JE. Educação bioética para profissionais da saúde. Bioethikos. 2012;6(1):66-77.

68. Gomes J, Barros CAC. Bioética no Ensino Superior. (Monografia). Rio de Janeiro (RJ): Universidade Cândido Mendes, 2009.

69. Hellmann F, Verdi MIM. Ética, bioética e deontologia no ensino da naturologia no Brasil. Rev bioét. 2014;22(3):529-39.

70. Rego S. A formação ética dos médicos: saindo da adolescência com a vida (dos outros) nas mãos. 1를 $\mathrm{ed}$. Rio de Janeiro: Editora Fiocruz; 2003.

71. Costa SIF, Diniz D. Introdução à Bioética. O Mundo da Saúde, São Paulo. 1999;23(3):187-88.

72. Villamil HR. Pertinencia de la bioética global en la educación universitaria. Rev Latinoam Bioet. 2007;8:28-43. 
73. Figueiredo LC. Abordagens bioéticas e Deontológicas do Código de Ética Profissional para Fisioterapeutas e Terapeutas Ocupacionais no Brasil. (dissertação). Brasília (DF): Universidade de Brasília, 2013.

74. Rodrigues N. Educação: da formação humana à construção do sujeito ético. Educ Soc, Campinas. 2001;22(76):232-57

75. Hermann N. Ética: a aprendizagem da arte de viver. Educ Soc, Campinas. 2008;29(102):15-32. 
APÊNDICE

\section{UNIVERSIDADE DE BRASÍLIA \\ FACULDADE DE CIÊNCIAS DA SAÚDE \\ PROGRAMA DE PÓS-GRADUAÇÃO EM CIÊNCIAS DA SAÚDE \\ DOUTORADO EM CIÊNCIAS DA SAÚDE}

As disciplinas de ética e bioética no curso de fisioterapia em universidades e centros universitários no brasil

\section{Parte I - Pesquisa das Instituições}

1- Instituição de Ensino:

2- Região a que pertence a Instituição de Ensino:

1 ( ) Norte

3( )Centro-Oeste

4( ) Sudeste

2( )Nordeste

5 ( )Sul

3- Estado a que pertence a Instituição de Ensino:

1( )Amazonas

2( ) Acre

3( )Roraima

4( )Rondônia

5( )Amapá

6( )Pará

7( )Tocantins

8( )Mato Grosso

9( )Distrito Federal
10( )Goiás

11( )Mato Grosso do Sul

12( )Maranhão

13( )Piauí

14( )Ceará

15( )Pernambuco

16( )Rio Grande do Norte

17( )Paraíba

18( )Alagoas
19( ) Sergipe

20( )Bahia

21( )Espírito Santo

22( )Rio de Janeiro

23( ) São Paulo

24( )Minas Gerais

25( )Paraná

26( )Santa Catarina

27( )Rio Grande do Sul

4- Natureza Jurídica:

1( ) Pública Federal

3( ) Privada

2( ) Pública Estadual

4( ) Pública Municipal

5- Organização Acadêmica: 1( ) Universidade

2( ) Centro Universitário 
6- Carga horária do curso de fisioterapia:

1( ) abaixo de 3000 horas 3( )Acima de 4000 horas

2 ( ) 3000 a 4000 horas

7- Quantidade de períodos o curso de fisioterapia possui:
1() 8
2( ) 9
3() 10

\section{Parte I - Pesquisa das disciplinas de Ética e ou Deontologia e Bioética}

8- Possui na estrutura curricular a disciplina de Bioética? 1( ) Sim

2( ) Não

9- Qual semestre a disciplina é ministrada?

$\begin{array}{lll}1() 1^{\circ} & 5() 5^{\circ} & 9() 9^{\circ} \\ 2() 2^{\circ} & 6() 6^{\circ} & 10() 10^{\circ} \\ 3() 3^{\circ} & 7() 7^{\circ} & \\ 4() 4^{\circ} & 8() 8^{\circ} & \end{array}$

10- Qual a carga horária da disciplina de Bioética?
1( )abaixo de 30 horas
3( )de 41 a 60 horas
2( ) de 30 a 40 horas
4( ) acima de 60horas

11- Possui na estrutura curricular a disciplina de Ética e ou Deontologia?
1( ) Sim
2( ) Não

12- Qual semestre a disciplina é ministrada?
1() $1^{\circ}$
5() $5^{\circ}$
9() $9^{\circ}$
2() $2^{\circ}$
6() $6^{\circ}$
10() $10^{\circ}$
3() $3^{\circ}$
7() $7^{\circ}$
4() $4^{\circ}$
8() $8^{\circ}$

13- Qual a carga horária da disciplina de Bioética?
1( )abaixo de 30 horas
3( )de 41 a 60 horas
2( ) de 30 a 40 horas
4( )acima de 60horas 
14- Possui na estrutura curricular a disciplina de Bioética vinculado a outra disciplina?
1( ) Sim
2( ) Não

Nome da disciplina:

15- Qual semestre a disciplina é ministrada?

$\begin{array}{lll}1() 1^{\circ} & 5() 5^{\circ} & 9() 9^{\circ} \\ 2() 2^{\circ} & 6() 6^{\circ} & 10() 10^{\circ} \\ 3() 3^{\circ} & 7() 7^{\circ} & \\ 4() 4^{\circ} & 8() 8^{\circ} & \end{array}$

16- Qual a carga horária da disciplina de Bioética vinculada?
1( )abaixo de 30 horas
3( )de 41 a 60 horas
2( ) de 30 a 40 horas
4( ) acima de 60horas

17- Possui na estrutura curricular a disciplina de Ética vinculado a outra disciplina?
1( ) Sim
2( ) Não

Nome da disciplina:

18- Qual semestre a disciplina é ministrada?

$\begin{array}{lll}1() 1^{\circ} & 5() 5^{\circ} & 9() 9^{\circ} \\ 2() 2^{\circ} & 6() 6^{\circ} & 10() 10^{\circ} \\ 3() 3^{\circ} & 7() 7^{\circ} & \\ 4() 4^{\circ} & 8() 8^{\circ} & \end{array}$

19- Qual a carga horária da disciplina de Ética vinculada?
1( )abaixo de 30 horas
3( )de 41 a 60 horas
2( ) de 30 a 40 horas
4( )acima de 60horas

16- Qual a carga horária da disciplina de Bioética vinculada?
1( )abaixo de 30 horas
3( )de 41 a 60 horas
2( ) de 30 a 40 horas
4( )acima de 60horas

20- Possui na estrutura curricular alguma disciplina que contemple em seu contexto o conteúdo de ética e ou deontologia e bioética? 
1( ) Sim

2( ) Não

Nome da disciplina:

21- Qual semestre a disciplina é ministrada?

$\begin{array}{lll}1())^{\circ} & 5() 5^{\circ} & 9() 9^{\circ} \\ 2() 2^{\circ} & 6() 6^{\circ} & 10() 10^{\circ} \\ 3() 3^{\circ} & 7() 7^{\circ} & \\ 4() 4^{\circ} & 8() 8^{\circ} & \end{array}$

22- Qual a carga horária da disciplina?

1( )abaixo de 30 horas

3( )de 41 a 60 horas

2( ) de 30 a 40 horas

4( ) acima de 60horas

23- Possui ementa da disciplina?

1( ) Sim

2( ) Não

*Anexar ementa ou plano de ensino ou projeto pedagógico.

24- Abordagem da ementa da Disciplina de Bioética:
( )Histórica
( )Filosófica
( )Temática

25- Apresenta o docente que leciona a disciplina assim como a sua titulação?
$1($ ) Sim
2( )Não 